\title{
Ancestral Caddo Ceramics in East Texas
}

Timothy K. Perttula

Heritage Research Center, Stephen F. Austin State University

Robert Z. Selden Jr.

Heritage Research Center, Stephen F. Austin State University

Follow this and additional works at: https://scholarworks.sfasu.edu/ita

Part of the American Material Culture Commons, Archaeological Anthropology Commons, Environmental Studies Commons, Other American Studies Commons, Other Arts and Humanities Commons, Other History of Art, Architecture, and Archaeology Commons, and the United States History Commons

Tell us how this article helped you.

This Article is brought to you for free and open access by the Center for Regional Heritage Research at SFA ScholarWorks. It has been accepted for inclusion in Index of Texas Archaeology: Open Access Gray Literature from the Lone Star State by an authorized editor of SFA ScholarWorks. For more information, please contact cdsscholarworks@sfasu.edu. 


\section{Ancestral Caddo Ceramics in East Texas}

Creative Commons License

(c) () () (9)

This work is licensed under a Creative Commons Attribution-NonCommercial 4.0 International License 


\title{
Ancestral Caddo Ceramics in East Texas
}

\author{
Timothy K. Perttula and Robert Z. Selden, Jr.
}

\section{INTRODUCTION}

The most distinctive material culture item of the ancestral Caddo groups that lived in East Texas (Figure 1) from ca. A.D. 900 to the 1830 s were the ceramics they manufactured primarily for cooking, storage, and serving needs. The decorative styles and vessels forms of the ceramics found at sites in the region hint at the variety, temporal span, and geographic extent of a number of ancestral Caddo groups that lived in this area. The diversity in decoration and shape of Caddo ceramics is considerable, both in the utility ware jars and bowls, as well as in the fine ware bottles, carinated bowls, and compound vessels. Ceramics are quite common in domestic contexts on habitation sites across the region, and whole vessels also occur as grave goods in mortuary contexts.

The Caddo manufactured ceramics in a wide variety of vessel shapes, and with an abundance of wellcrafted and executed body and rim designs paired with smoothed, burnished, or polished surface treatments. From the archaeological contexts in which Caddo ceramics have been found, as well as through inferences about their manufacture and use, it is evident that ceramics were important to the ancestral Caddo in: the cooking and serving of foods and beverages, for the storage of foodstuffs, as personal possessions, as incense burners, as beautiful works of art and craftsmanship (i.e., some vessels were clearly made to never be used in domestic contexts), and as social identifiers. In the case of the later, certain shared and distinctive stylistic motifs and decorative patterns on ceramic vessels marked closely related communities and constituent groups.

The stylistic analysis of Caddo ceramics from sites in East Texas has focused on the definition of recognizable decorative elements, patterns, and motifs on the rim and/or body for the wide range of fine wares (i.e., the engraved and red-slipped vessels, including carinated bowls and bottles) and utility wares, usually cooking or storage jars and simple bowls. These decorative distinctions have both temporal and geographical distributions across East Texas, and in some cases, across the broader Caddo area, and identifying and recognizing those distributions has been a substantive clue to the reconstruction of settlement and regional histories of different Caddo communities as well as their socio-cultural character.

The stylistic distinctions that have been recognized in East Texas Caddo ceramics are based primarily upon the pioneering typological research carried out by Alex D. Krieger, Clarence Webb, Dee Ann Suhm (Story) and Edward B. Jelks in the 1950s and early 1960s. In 1962, Suhm and Jelks presented descriptions of 60 Caddo ceramic types that had been identified in Caddo sites in East Texas and the Caddo archaeological area up to that time. According to Suhm and Jelks (2009:3), since 1962:

the Caddoan [sic] types, at least those found in Texas, have changed surprisingly little, more tweaked than substantially altered. Elsewhere in the Caddoan [sic] area, a relatively modest number (considering the amount of pottery usually found at the sites) of new types have been defined, although many varieties of existing types have been introduced and design motifs, even design element categories, have been recognized, especially by archeologists working in Arkansas.

While the ceramic types defined by Suhm et al. and Suhm and Jelks in 1954 and 1962, respectively, remain in use as classificatory constructs for Caddo archaeological research, a number of new Caddo ceramic 


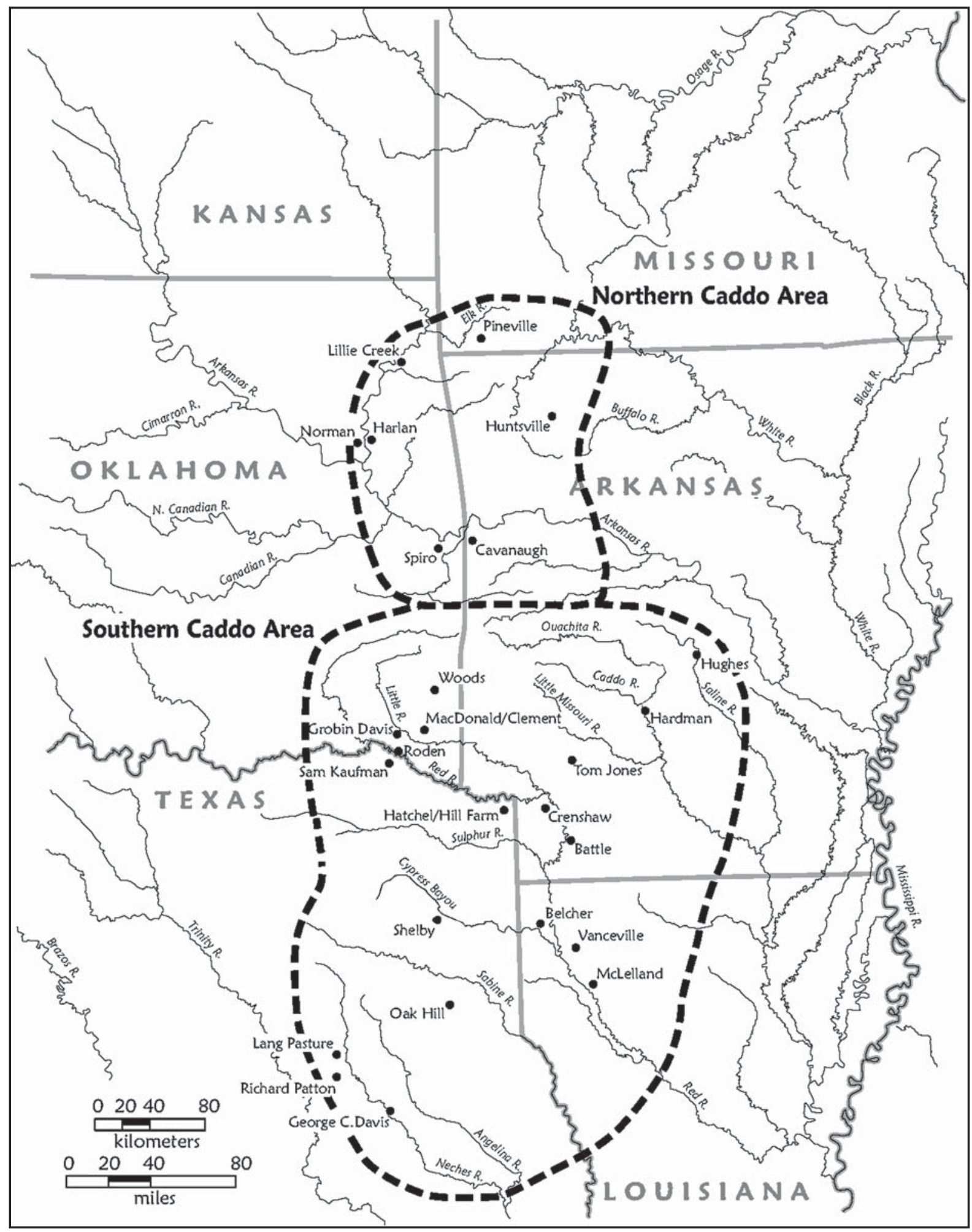

Figure 1. The Southern and Northern Caddo Areas in Arkansas, Louisiana, Oklahoma, and Texas. Figure prepared by Sandra Hannum. 
types have been recognized and identified in East Texas archaeological sites since the mid-1960s - some better defined than others. Most of them are poorly known among archaeologists that work on Caddo sites in the region. Some new varieties have also been identified among several of the well-known types defined in the 1950s, including Poynor Engraved, Hume Engraved, Ripley Engraved, and Wilder Engraved (see below); these varieties may have more discrete temporal and geographic boundaries than when first defined.

Many archaeologists working in the East Texas Caddo area continue to rely, erroneously, on the estimated ages of types offered by Suhm and Jelks (1962). However, with the advent of relatively extensive radiocarbon dating of Caddo sites in the region - and the seriation of burials in cemeteries of different ages - as well as many new archaeological research investigations, much more accurate temporal estimates for the manufacture and use of ancestral Caddo pottery types are becoming apparent. Distinctive sets of ceramic vessels and assemblages of different ages and areas occur within the region.

\section{CADDO CERAMIC SETS}

Table 1 represents our initial efforts to partition the known ancestral Caddo ceramic sets in East Texas. The stylistic diversity in the decorated wares from East Texas Caddo sites has led to the recognition of distinctive stylistic motifs and types with unique spatial and temporal distributions (although these are still being refined) (Figures 2-5). The distribution of these ceramic sets can be linked with the identification of culturally specific Caddo groups, phases, and vessel assemblages in the East Texas archaeological record.

Table 1. East Texas and mid-Red River Caddo Ceramic Sets.

\section{Early Caddo set, ca. A.D. 900-1300}

Bowles Creek Plain

Canton Incised

Coles Creek Incised

Crenshaw Fluted

Crenshaw Lobed

Crockett Curvilinear Incised

Davis Incised

Dunkin Incised

Duren Neck Banded

Hickory Engraved, including Hickory Engraved, var. Chapman

Holly Engraved

Hollyknowe Pinched

Kiam Incised

Pennington Punctated-Incised

Spiro Engraved

Weches Fingernail Impressed

Williams Plain

Middle Caddo set, ca. A.D. 1100/1200-1300/1400, upper Red River, cf. Sanders phase, and in parts of East Texas

Antioch Engraved

Canton Incised

Leaning Rock Engraved

Maxey Noded Redware

Monkstown Fingernail Impressed 
Table 1. East Texas and mid-Red River Caddo Ceramic Sets, cont.

Paris Plain

Sanders Engraved

Sanders Plain

Spoonbill Engraved

Spoonbill Plain

Broaddus Brushed

Nacogdoches Engraved

Pineland Punctated-Incised

Reavely Brushed-Incised

Tyson Engraved

Washington Square Paneled

Middle Caddo set, lower Red River, ca. A.D. 1200-1400

Dunkin Incised

East Incised

Friendship Engraved

Haley Complicated Incised

Haley Engraved

Handy Engraved

Hempstead Engraved

Pease Brushed-Incised

Late Caddo Belcher phase set, ca. A.D. 1500-1680

Avery Engraved

Belcher Engraved

Belcher Ridged

Cowhide Stamped

Foster Trailed-Incised

Glassell Engraved

Hodges Engraved

Karnack Brushed-Incised

Moore Noded

Taylor Engraved

\section{Latest Belcher phase set, $1680+$ (and other post-1680 contexts)}

Natchitoches Engraved

Hodges Engraved

Glassell Engraved

Keno Trailed

Ebarb Incised

Foster Trailed-Incised 
Table 1. East Texas and mid-Red River Caddo Ceramic Sets, cont.

McCurtain phase set, ca. A.D. 1300/1400-1700

Avery Engraved

Clark Engraved

Emory Punctated-Incised

Hudson Engraved

McKinney Plain

Nash Neck Banded (shell)

Simms Engraved

Texarkana phase set, ca. A.D. 1400/1450-late 17th century

Avery Engraved

Barkman Engraved

Bowie Engraved

Foster Trailed-Incised

Hatchel Engraved

Karnack Brushed-Incised

Keno Trailed (latest part of phase)

McKinney Plain

Moore Noded

Nash Neck Banded (primarily grog)

Pease Brushed-Incised

Simms Engraved

Frankston phase set, ca. A.D. 1400-1650

Bullard Brushed

Fair Plain

Hood Engraved (effigy bowls)

Hume Engraved, several varieties (Perttula et al. 2011:Figure 6-66e-g) (Figure 6e-g)

Hume Plain

Killough Pinched

La Rue Neck Banded

Maydelle Incised

Poynor Brushed

Poynor Engraved, multiple varieties (Perttula et al. 2011:Figures 6-64 and 6-65) (Figure 7 and 8)

Allen phase, ca. post-A.D. 1650

Bullard Brushed

Constricted Neck Punctated

Hood Engraved (effigy bowls)

Hume Engraved

Hume Plain

Killough Pinched

King Engraved

La Rue Neck Banded

Lindsey Grooved

Mayhew Rectilinear

Patton Engraved, several varieties (Perttula et al. 2011:Figure 6-66a-d) (Figure 6a-d)

Spradley Brushed-Incised 
Table 1. East Texas and mid-Red River Caddo Ceramic Sets, cont.

Kinsloe phase, post A.D. 1680-1830

Darco Engraved

Emory Punctated-Incised

Henderson Plain

Keno Trailed

Natchitoches Engraved

Patton Engraved

Simms Engraved

Titus phase set, ca. A.D. 1430-1680

Anglin Corn Cob Impressed

Bailey Engraved

Bullard Brushed

Cass Appliqued

Gardener Punctated

Gilmer Engraved

Harleton Appliqued

Johns Engraved

Karnack Brushed-Incised

Killough Pinched

La Rue Neck Banded

Maydelle Incised

Mockingbird Punctated

Pease Brushed-Incised

Ripley Engraved, multiple varieties (Figure 9a-k)

Taylor Engraved

Turner Engraved, multiple varieties (Figure 10a-d)

Wilder Engraved, multiple varieties

Latest set in Titus phase area, ca. A.D. 1680+ (best known at the Clements site [41CS25])

Clements Brushed

Darco Engraved

Hatinu Engraved

Keno Trailed

Simms Engraved

Taylor Engraved

Post-A.D. 1680, mid-Red River and upper Sabine River basin as well as Mission Dolores de los Ais

Ebarb Incised

Emory Punctated-Incised

Natchitoches Engraved

Simms Engraved

Womack Engraved

Womack Plain 


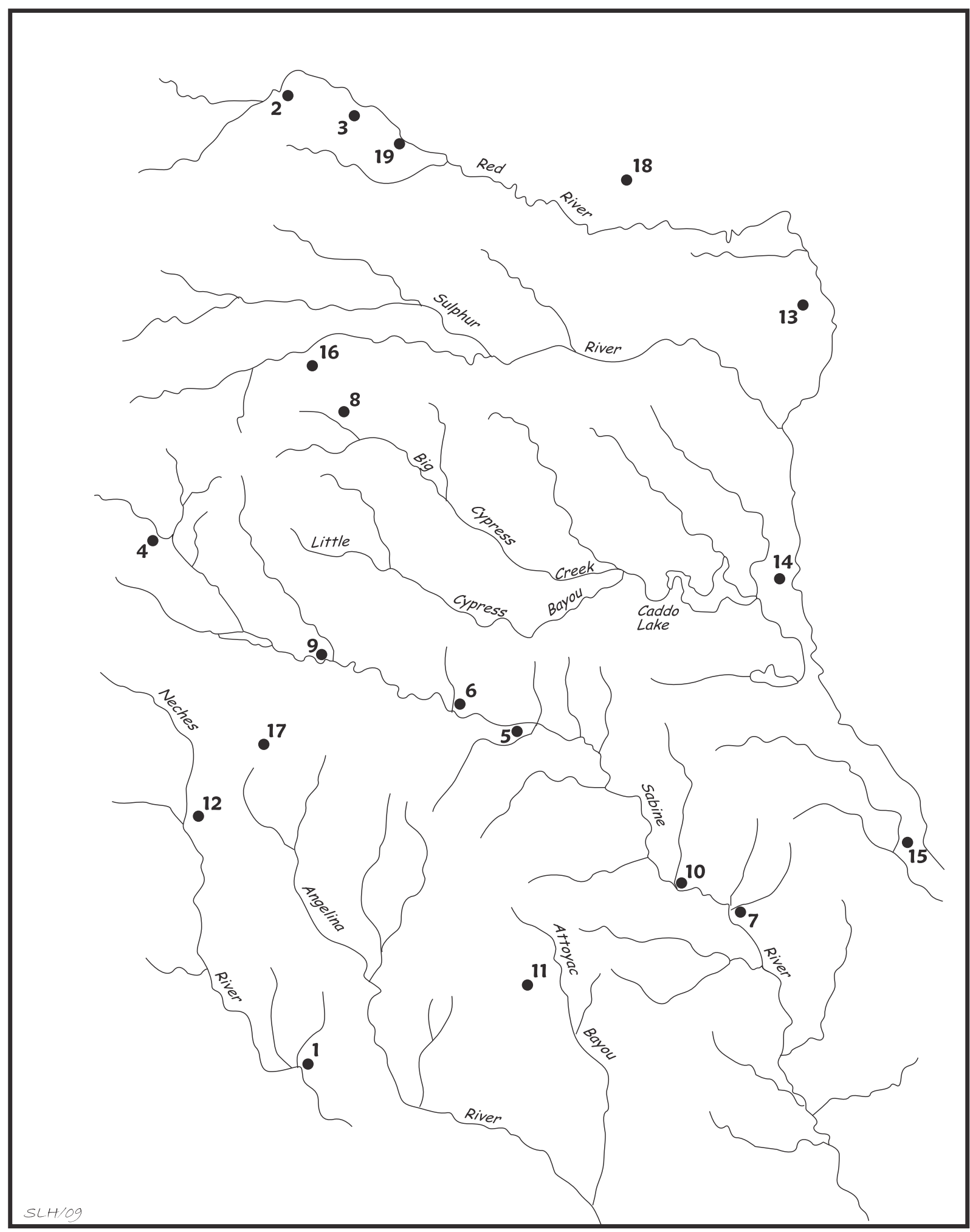

Figure 2. Important Early Caddo sites: 1, George C. Davis; 2, Fasken; 3, Roitsch; 4, Taddlock; 5, HudnallPirtle; 6, Grace Creek; 7, Bison A; 8, Hale; 9, Boxed Springs; 10, Pace; 11, Boyette; 12, Joe Meyers; 13, Crenshaw; 14, Mounds Plantation; 15, Gahagan; 16, Jaggers; 17, Henry Chapman; 18, Bowman; 19, BentsenClark. Figure prepared by Sandra Hannum. 


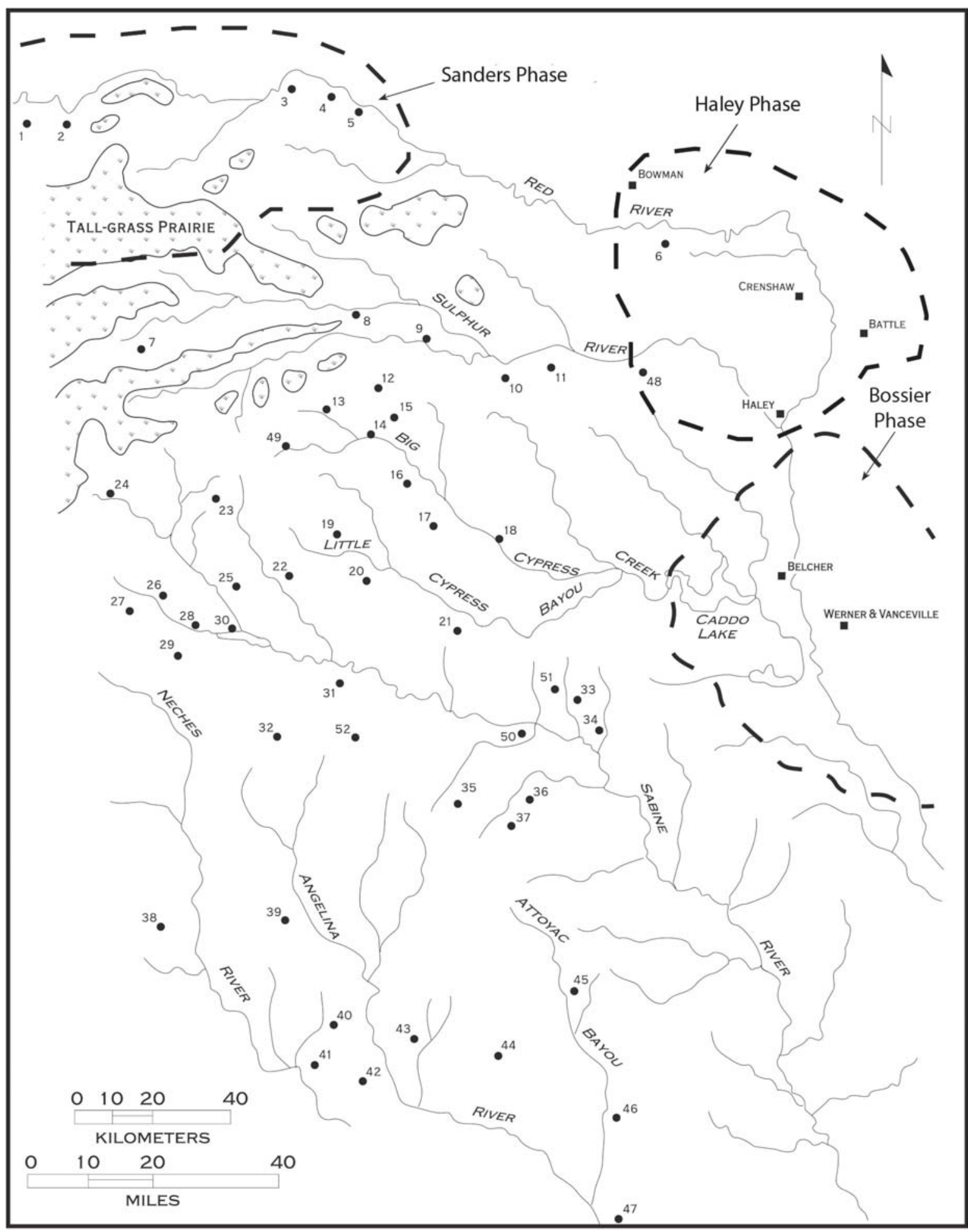

Figure 3. Important Middle Caddo sites, major Red River Caddo centers occupied during the Middle Caddo period, and defined Middle Caddo period phases. 1, Harling; 2, Sanders; 3, Fasken; 4, Roitsch; 5, Holdeman; 6, Hatchel; 7, Hurricane Hill; 8, 41RR181 and Little Mustang Creek; 9, 41TT670; 10, 41CS150; 11, Coker (41CS1); 12, 41TT372; 13, 41FK70; 14, Benson's Crossing; 15, Crabb (41TT650); 16, Harold Williams; 17,41UR21; 18, Big Oaks; 19, Griffin Mound; 20, 41UR133; 21,41UR8; 22, McKenzie; 23, Spoonbill; 24, 41RA65; 25, T. M. Moody; 26, 41WD518; 27, Yarbrough; 28, Charlie Crews; 29, Jamestown; 30, Carlisle; 31, Langford; 32, Bryan Hardy; 33, 41HS74; 34, Old Brown Place; 35, Oak Hill Village; 36, 41PN14; 37, Musgano (41RK19); 38, Pace McDonald; 39, 41CE42; 40, 41CE289; 41, George C. Davis; 42, 41CE290; 43, 41NA20; 44, Washington Square; 45, Tyson; 46, 41SA123; 47, 41SA89; 48, Knight's Bluff; 49, 41FK7; 50, Hudnall-Pirtle; 51, Gray's Pasture; 52. Redwine. 


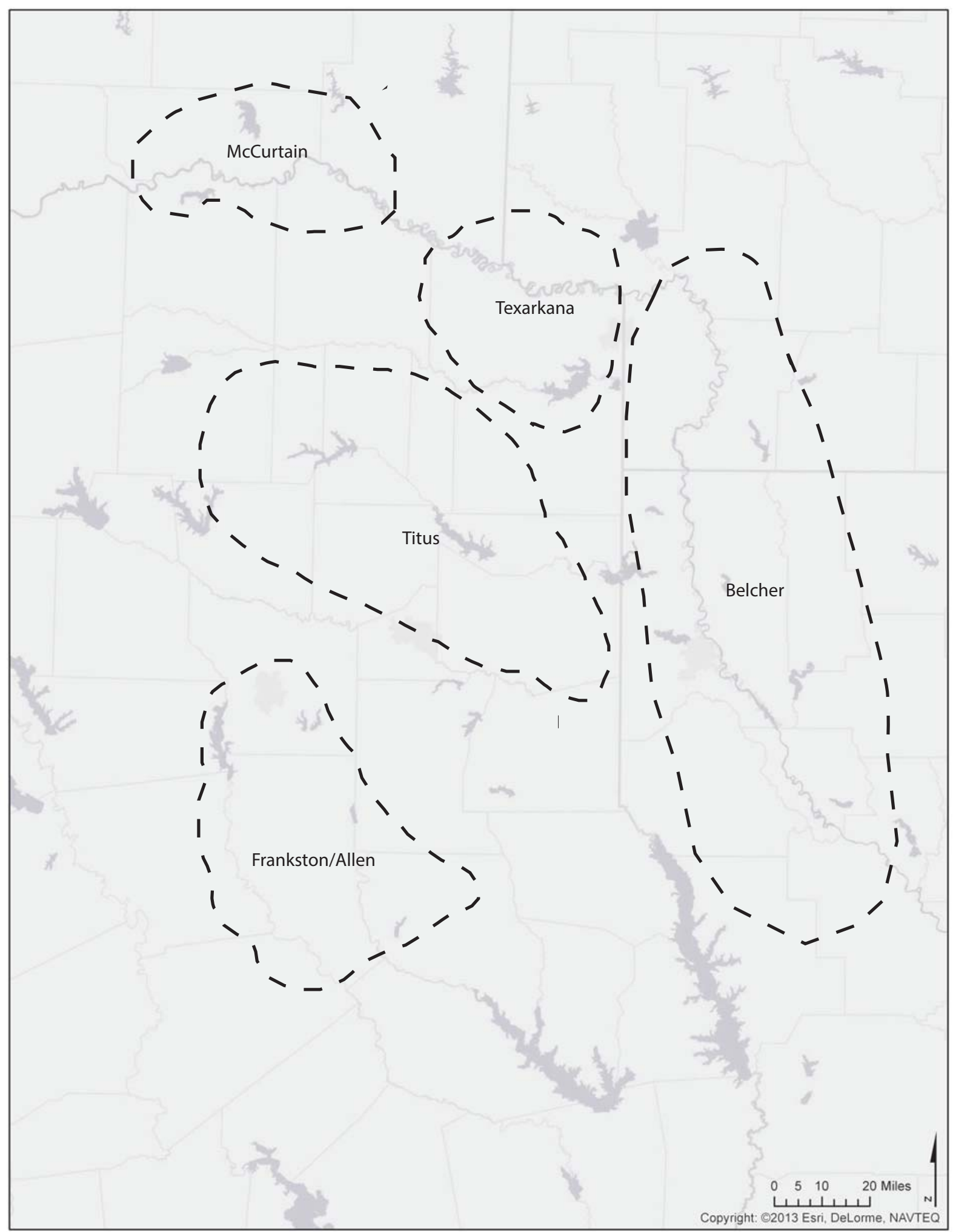

Figure 4. Late Caddo period phases in East Texas and immediately surrounding areas. 


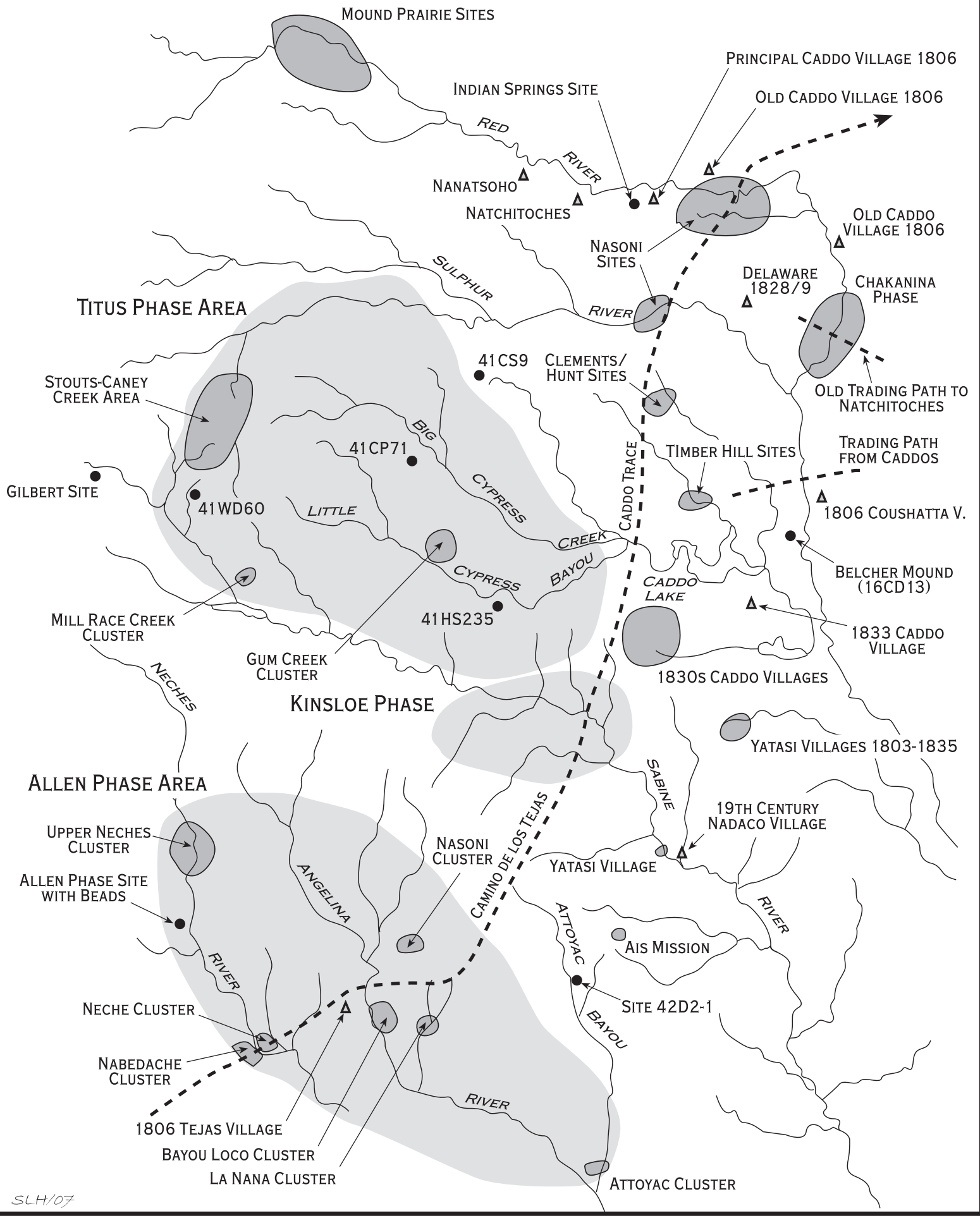

Figure 5. Clusters of Historic Caddo sites and defined phases. Figure prepared by Sandra Hannum. 


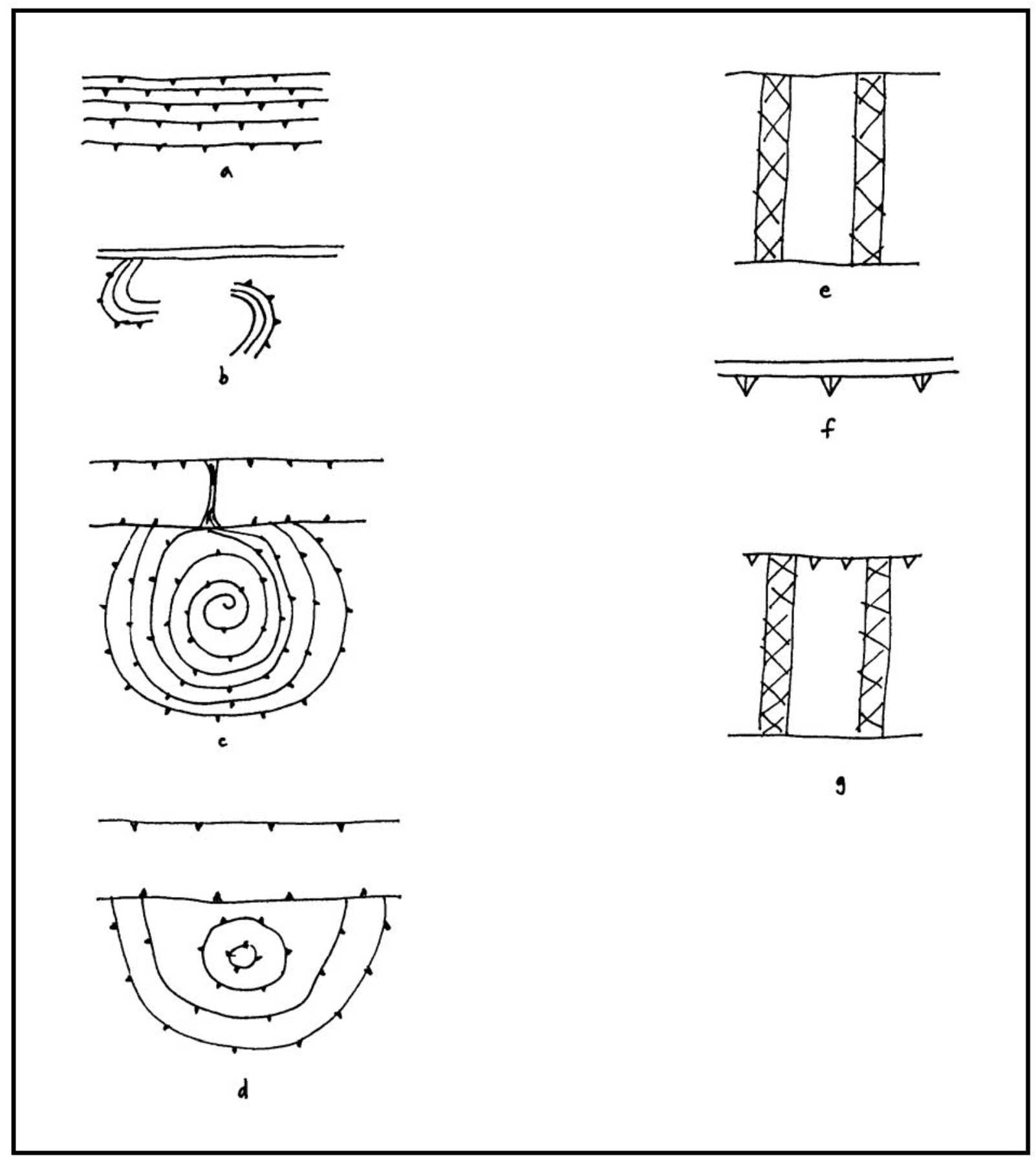

Figure 6. Defined Patton Engraved and Hume Engraved varieties in the upper Neches River basin: a, Patton Engraved, var. Allen; b, Patton Engraved, var. Patton; c, Patton Engraved, var. Freeman; d, Patton Engraved, var. Fair; e, Hume Engraved, var. Hume; f, Hume Engraved, var. Allen; g, Hume Engraved, var. unspecified. 

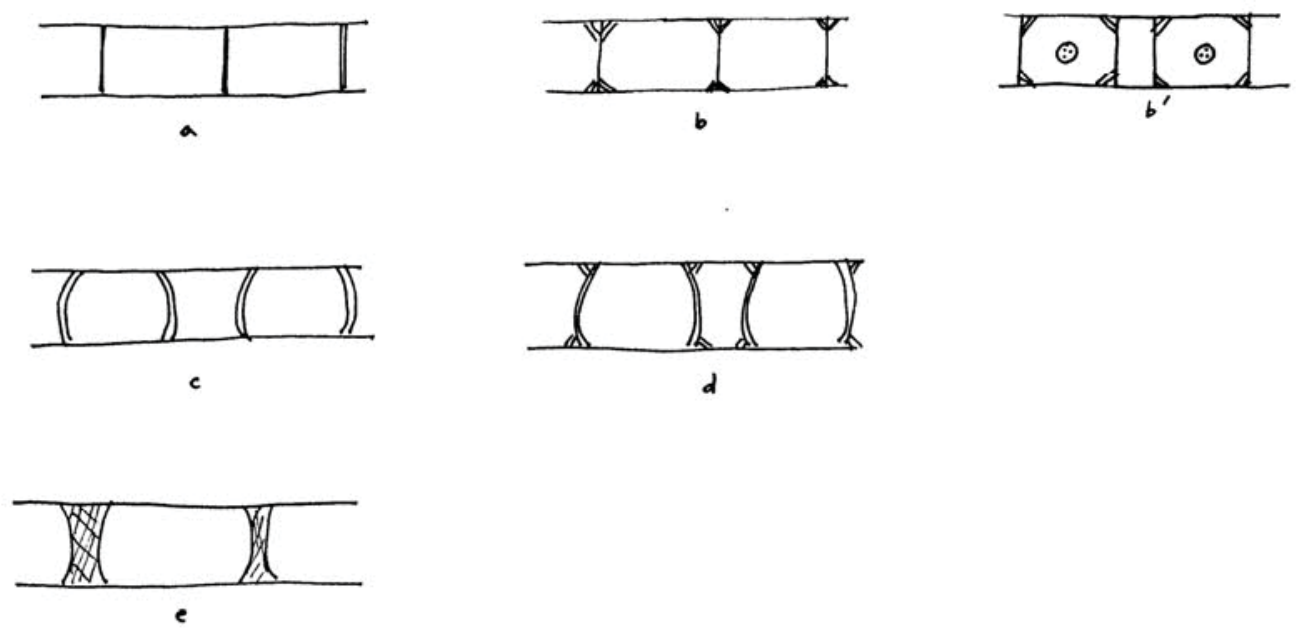
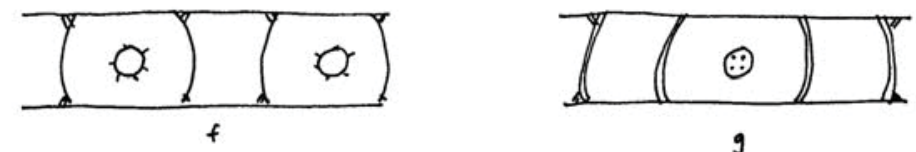

9

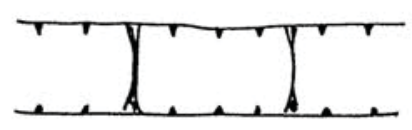

h
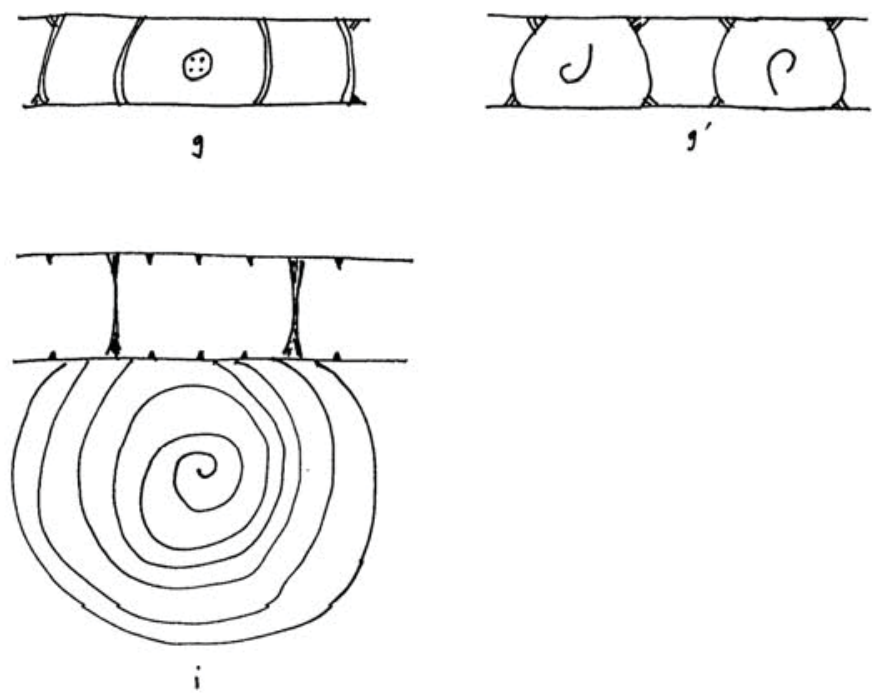

Figure 7. Defined varieties of Poynor Engraved: a-b', var. Blackburn; c-d, var. Cook; e, var. Hood; f-g', var. Lang; h-i, var. Freeman. 


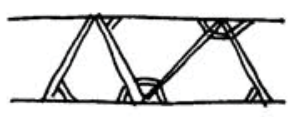

Var. A, Nested triangle

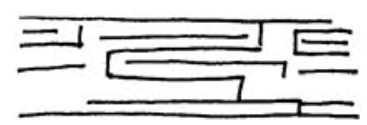

Var. B, horrizontal

and vertical interlocking scrolls

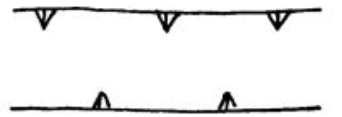

var. C, continuovs

hatched triangles

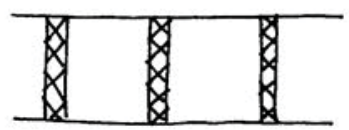

Var. D, vertical

cross-hatched panels

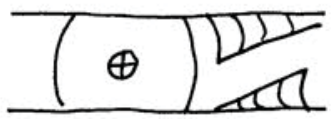

var. E, scroll and circle

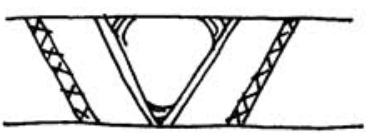

Var. F, Nested ovals and

diagonal cross-hatched ladders

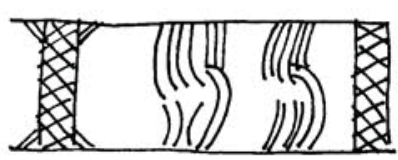

Var. G, hooked arm scroll and cross-hatched panels

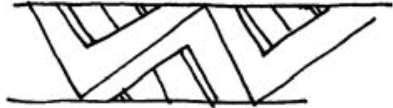

Var. I, cowtinuous

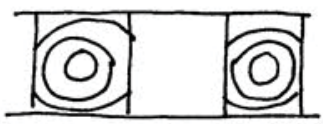

var. J, rectangular panel and wested circle

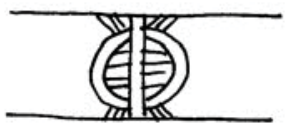

Var. $K$ semi-curcle and nested circles

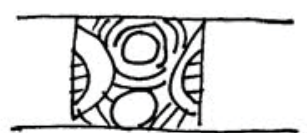

Var. L, rectangular

panel and negative circle

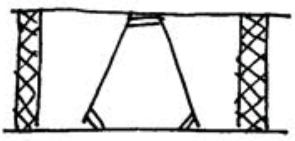

var. $m$, triangle and cross-hatched panel

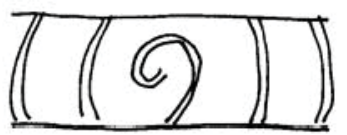

Var, $N$ hooked arm and oval

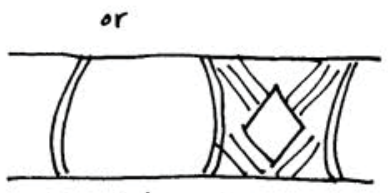

oval and diamond, var. $N^{\prime}$

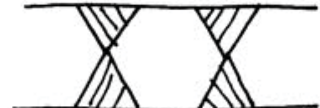

Var. 0, stacked

hatched triangles

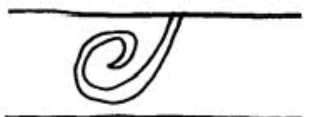

Var. P, hooked arm

or
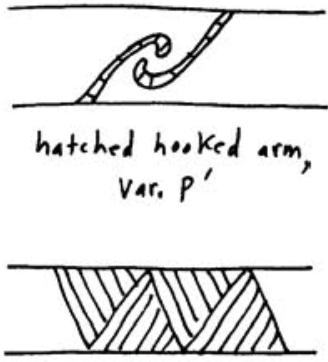

Var. $Q$, hatehed wested triangles

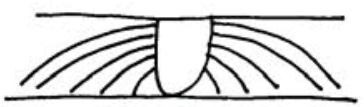

var. $R$, concentric semi-circle

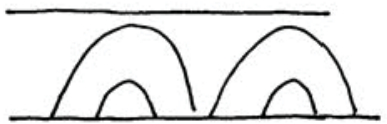

Var. S, concentic oval
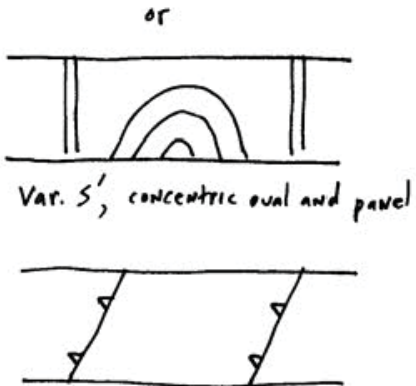

Var. T, diagowal with small pendant triangle

Figure 8. Local and regional varieties of Poynor Engraved in the upper Neches River basin (from Perttula et al. 2011:Figure 6-64). 


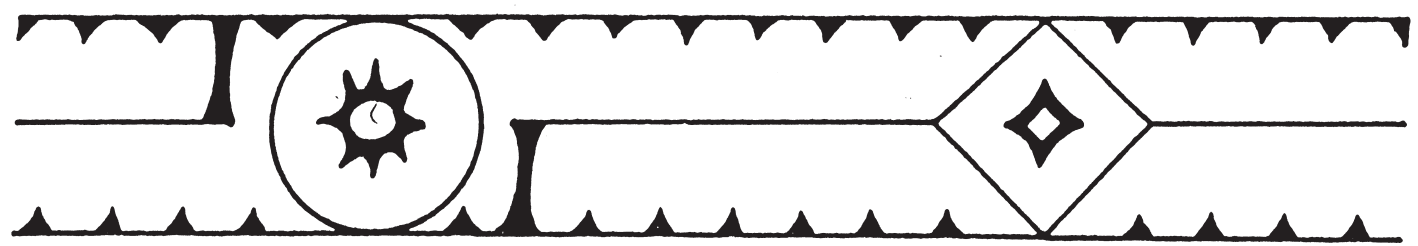

A
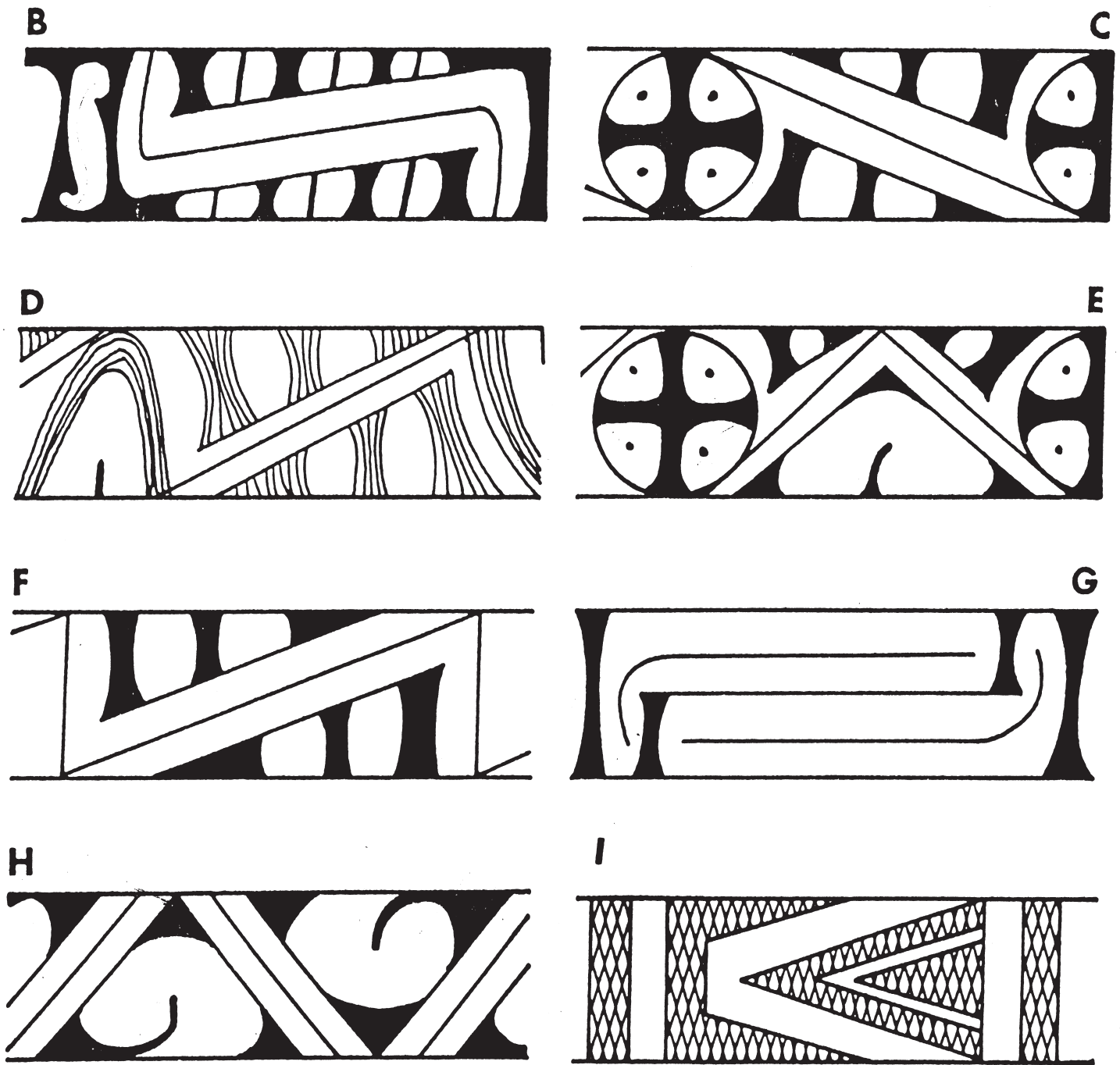

I
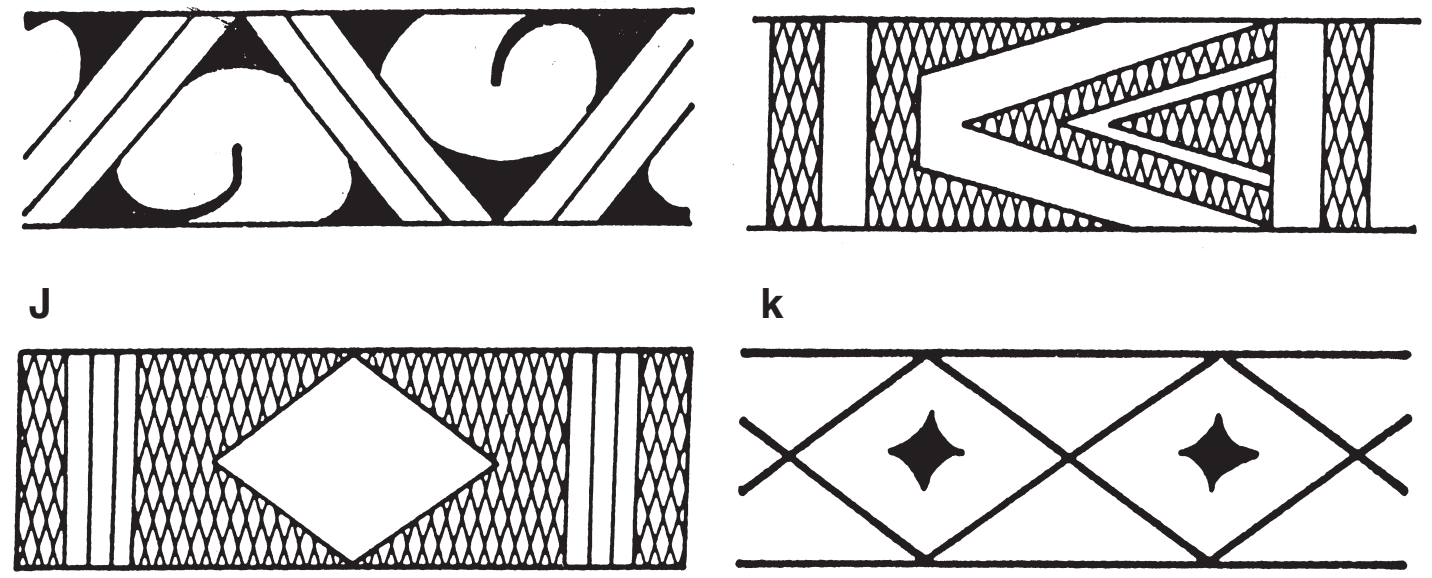

Figure 9. Defined varieties of Ripley Engraved: a, var. McKinney; b, var. Gandy; c, var. Galt; d, var. Caldwell; e, var. Cash; f, var. Carpenter; g, var. Pilgrims; h, var. Williams; i, var. Reed; j, horizontal diamond, var. unspecified; $\mathrm{k}$, interlocking diamond, var. unspecified. 


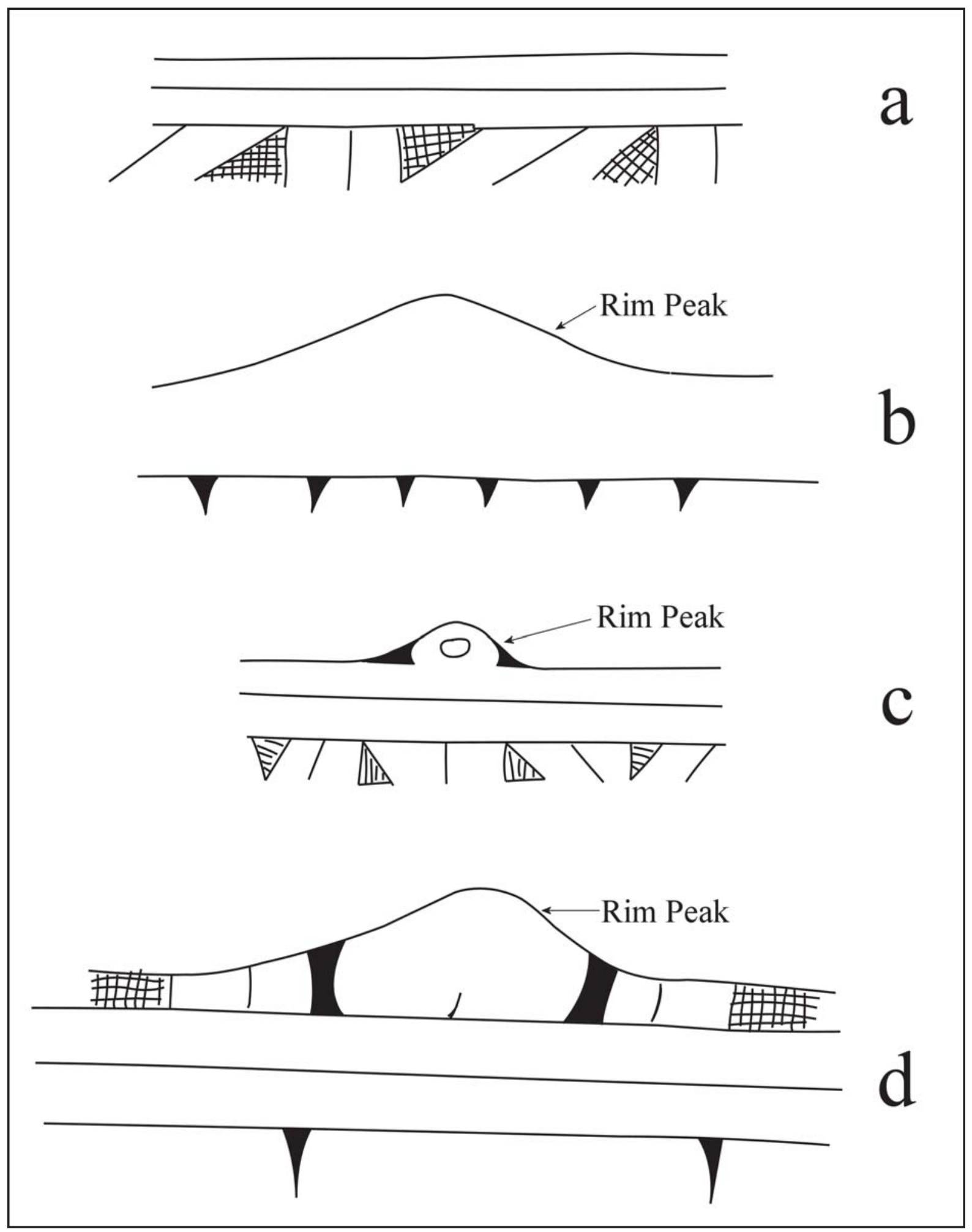

Figure 10. Turner Engraved and defined varieties: a-b, var. Turner; c-d, var. Horton. 


\section{NEW POST-1962 TYPES}

Through scouring the archaeological literature concerning archaeological investigations in the southern Caddo area, we have identified 40 ceramic types that have been described and defined - to varying extents since the seminal publication of Suhm and Jelks (1962). Each of these types are described below, noted by their apparent temporal period of occurrence; that is, from the Early Caddo period (ca. A.D. 850-1200) to the Historic Caddo period (post-ca. A.D. 1680). It should be noted that in almost every case, more chronometric dates are needed to clarify and expound upon these preliminary temporal definitions.

\section{Early Caddo}

\section{Bowles Creek Plain}

Bowles Creek Plain is an Early Caddo period ceramic type defined by Stokes and Woodring (1981:187) from the large sherd assemblage recovered at the George C. Davis site (41CE19) on the Neches River. This type occurs as carinated bowls, bottles, and jars tempered with grog and/or bone, and that have smoothed and polished surface treatments.

\section{Crenshaw Fluted}

Defined by Durham and Davis (1975:36 and Figure 19:I1, I3), sherds and vessels (barrel-shaped jars) of this type have been recovered in mound centers on the Red River (i.e., the Crenshaw site, 3MI6) and in the Sabine River basin (Boxed Springs, 41UR30). They have deep vertical grooves or flutes as the principal decorative element, although occasionally vessels include an engraved motif on the upper part of the vessel and a series of deep vertical grooves on the remainder of the vessel (Figure 11).

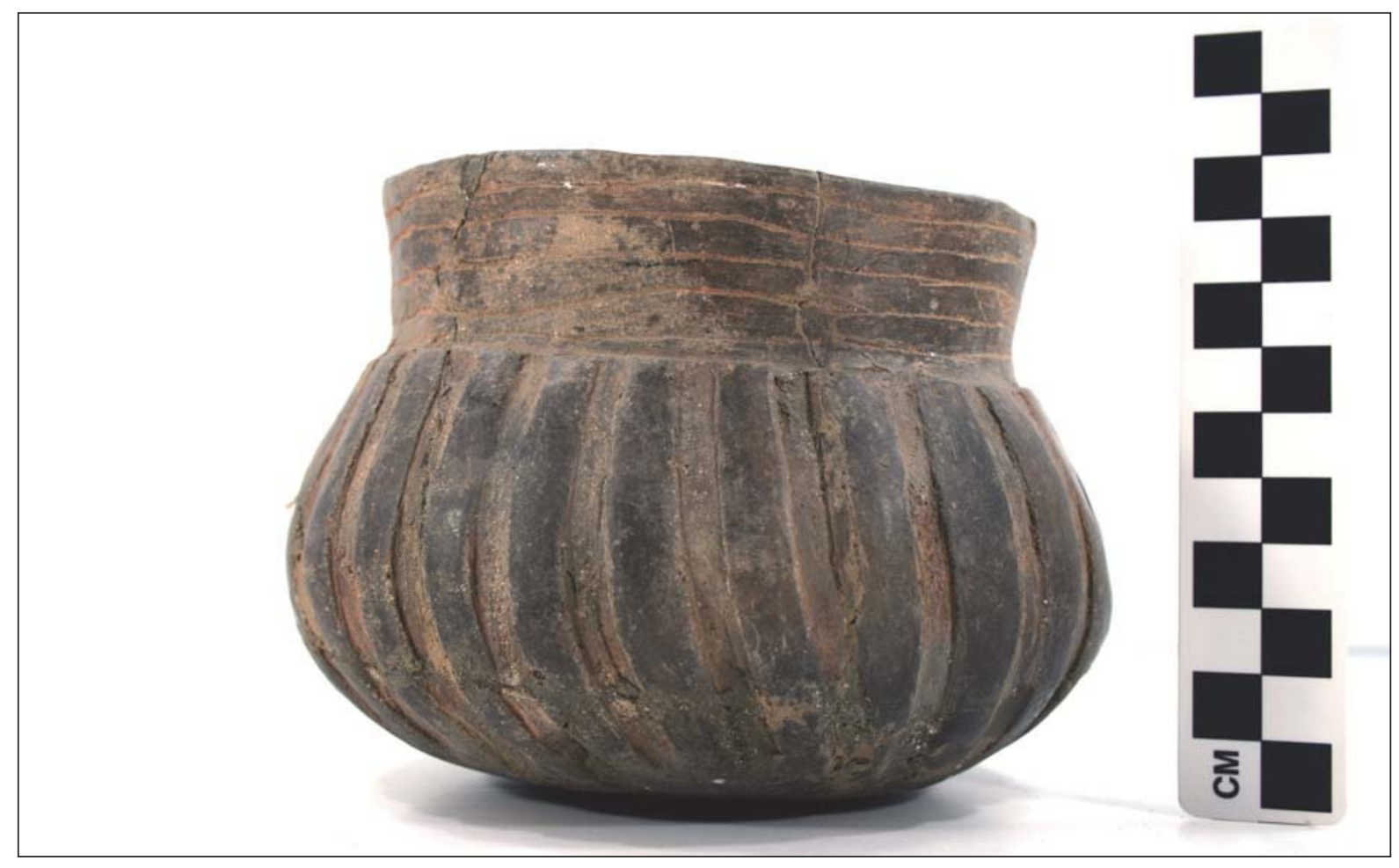

Figure 11. Crenshaw Fluted jar from the Crenshaw site, Miller County, Arkansas. 


\section{Crenshaw Lobed}

Crenshaw Lobed was defined by Durham and Davis (1975:11) based on vessels recovered from tombs in Mound $\mathrm{C}$ at the Crenshaw site. Approximately $7 \%$ of the vessels from this Early Caddo component at the Crenshaw site are of the Crenshaw Lobed type (Durham and Davis 1975); additionally, one Crenshaw Lobed vessel has been recovered and identified from the Spiro site in eastern Oklahoma.

The type is a grog-tempered beaker form with a series of prominent horizontal lobes or bulges on the vessel body (Durham and Davis 1975:Figure 31:N1, N3; Figure 38:Q25, Q27; Figure 40:Q39, Q40). There are from one to three lobes, or more, on the beakers (Figure 12a). Some examples of Crenshaw Lobed have various engraved lobes (Figure 12b).

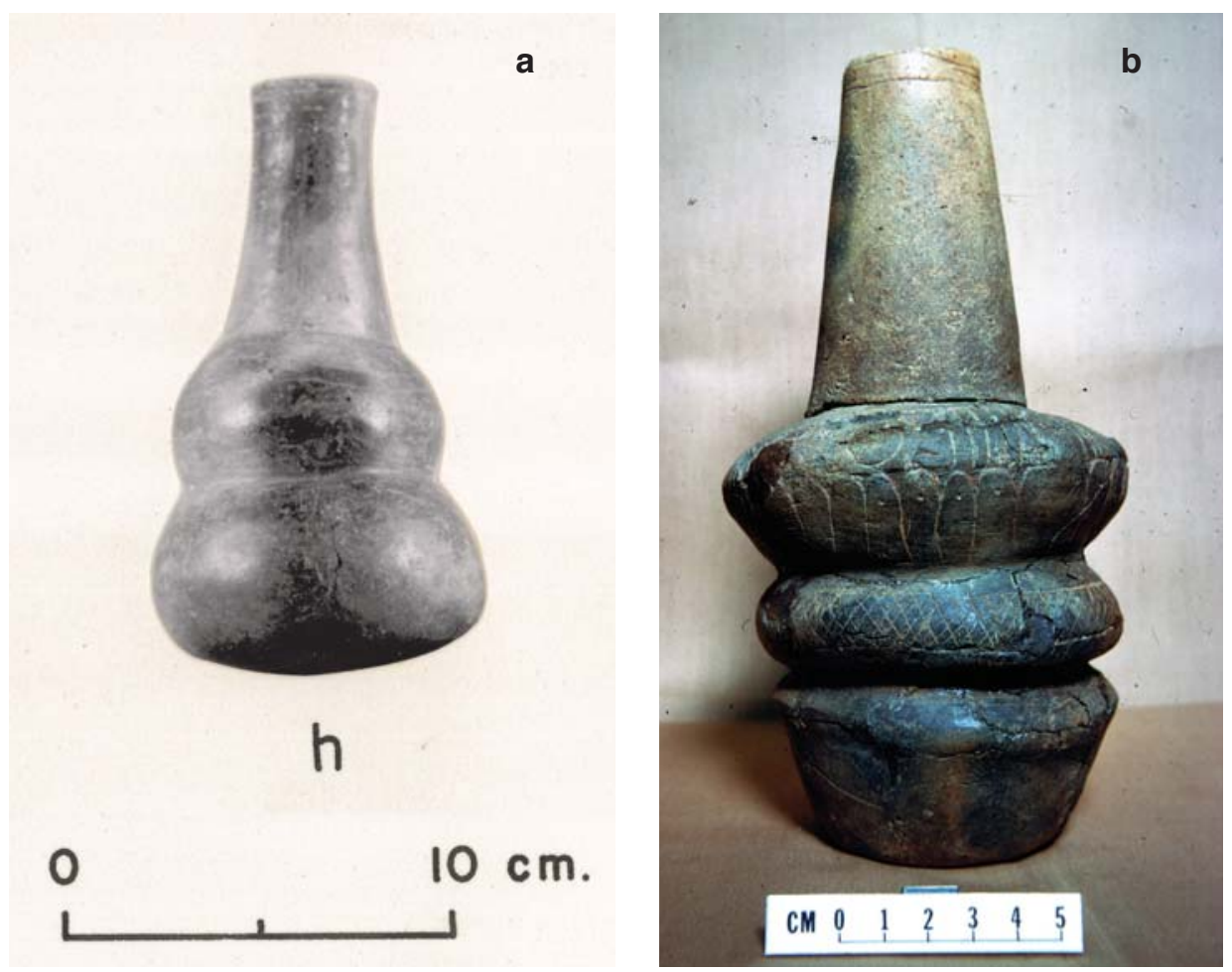

Figure 12. Crenshaw Lobed: plain lobed vessel from the Crenshaw site (from Wood 1962:Figure 23h); b, engraved variety of Crenshaw Lobed from the Crenshaw site. Image courtesy of John Samuelsen.

\section{Hollyknowe Pinched}

Hollyknowe Pinched is a utility ware that was defined on the basis of sherds from Early Caddo period habitation contexts at the Mounds Plantation site on the Red River in Northwestern Louisiana (Webb and McKinney 1975:84) as well as from Coles Creek period contexts in the lower Mississippi River basin (see Phillips 1970). It has also been found in similar contexts at Early Caddo mound centers in the mid-Sabine River basin (see Perttula 2011:Figure 34e and 36b, f). Hollyknowe Pinched Ridge vessels have vertical, parallel, straight, curvilinear and concentric pinched ridges on the body, and horizontal incised lines on the rim (Figure 13a-b). 

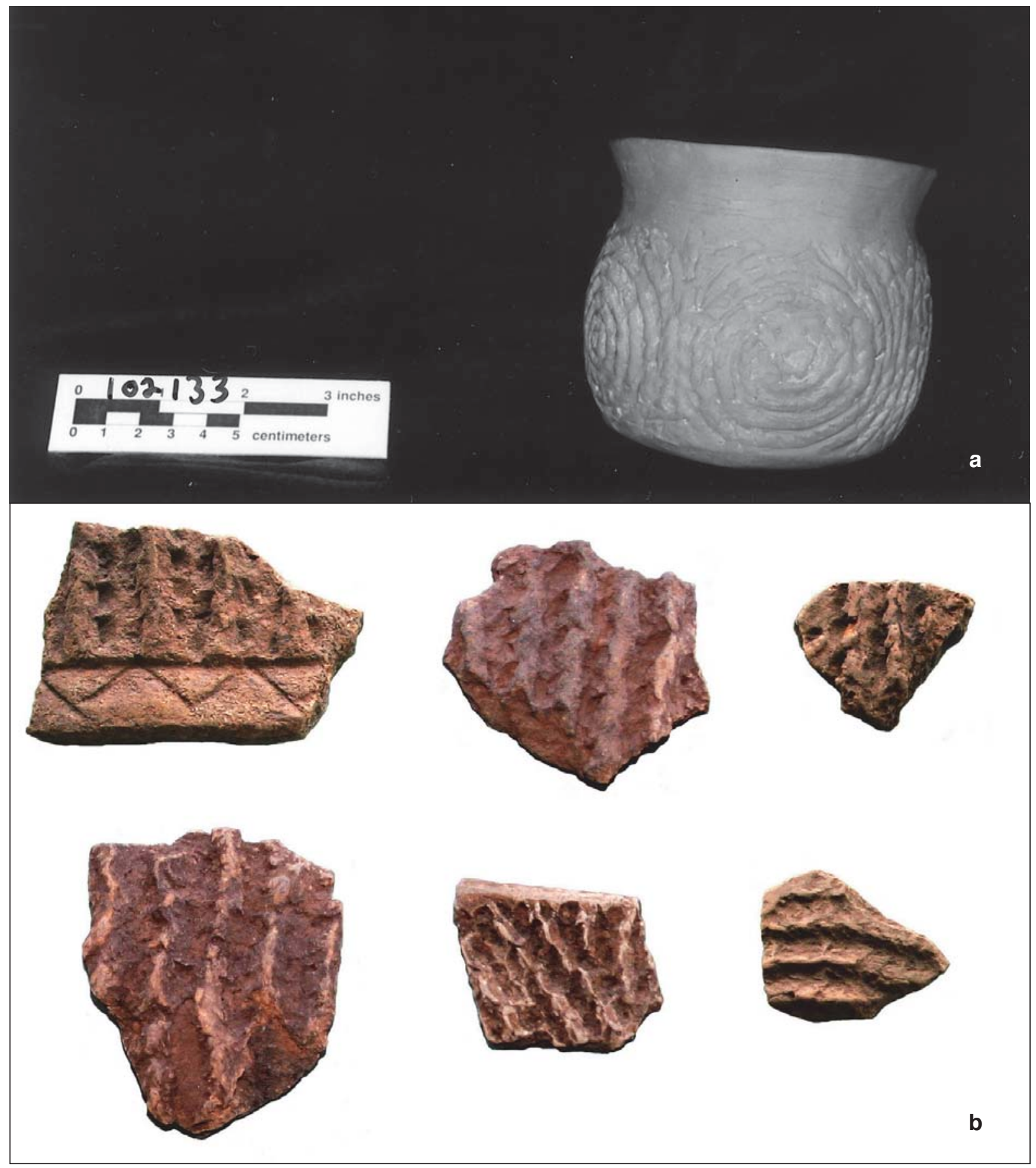

Figure 13. Hollyknowe Pinched Ridge: a, jar from the Boxed Springs site (41UR30), Upshur County, Texas; $\mathrm{b}$, sherds from the Mounds Plantation site (16CD12); image courtesy of Jeffrey S. Girard.

\section{Middle Caddo}

\section{Antioch Engraved}

Antioch Engraved is a fine ware type defined by Jelks (1961:29) from Caddo sites at Lake Wright Patman on the lower Sulphur River. The type is represented by a single form, bottles. The vessel bodies have engraved panels defined by either hatched ladders or cross-hatched zones and cross-hatched pendant triangles 
(Figure 14). Within the panels are circle motifs, some that have a series of attached curvilinear lines that extend from the circle to one of the panel dividers.

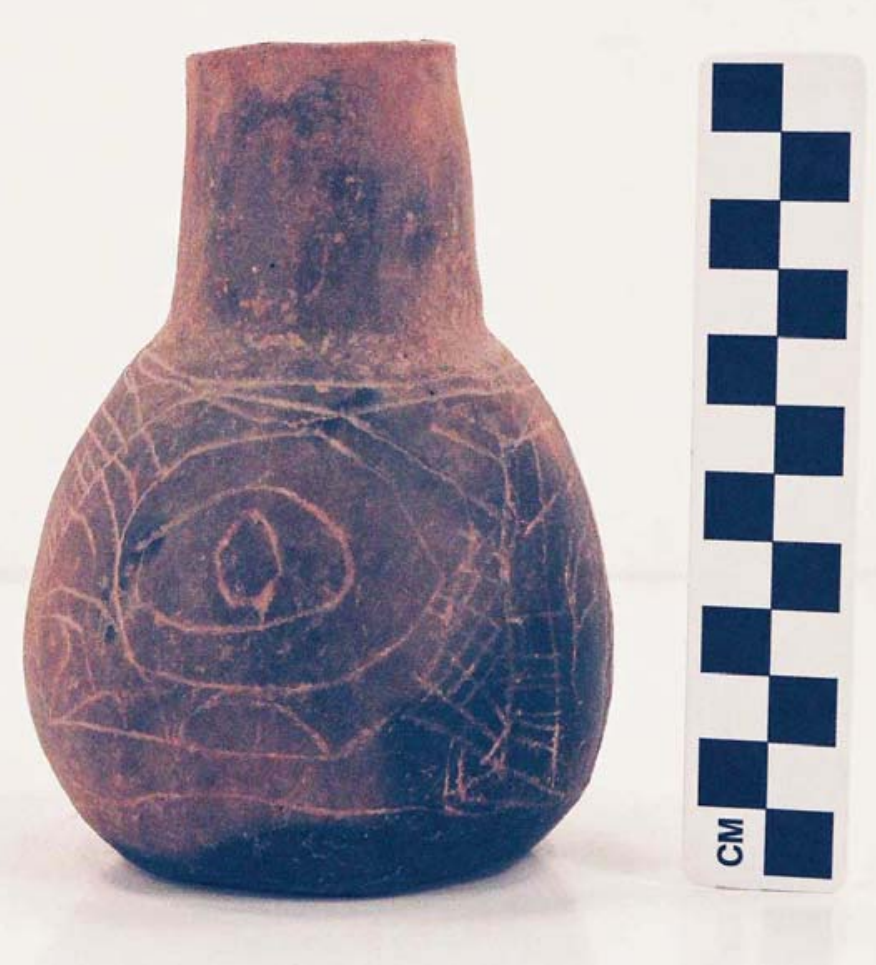

Figure 14. Antioch Engraved bottle.

\section{Leaning Rock Engraved}

This Middle Caddo period type was defined on the basis of rim sherds from the Leaning Rock site (41SM325) in the Sabine River basin. Perttula (2008:30) described the type as having "horizontal engraved lines that have a series of long diagonally ticked lines" pendant from the horizontal engraved lines.

\section{Paris Plain}

Paris Plain was defined and described by Brown (1996:348-349 and Figures 2-19e, k, m and 2-36d) using vessels and sherds from the Spiro site (34Lf40). Brown (1996:349) also included vessels that Krieger (1946:185-186 and Plates 24-26, 28; Suhm and Jelks 1962:139 and Plate 60c, f-g) had originally included in the Sanders Plain type.

Paris Plain is a grog-tempered and burnished plain ware, with both bowls and wide-mouthed bottles. Bowls have both vertical and inverted rim profiles.

\section{Sanders Plain}

As redefined by Brown (1996:401-403 and Figures 2-191, 2-34g, 2-37a-1, 2-38d, 2-39d, k, n-q, and 2-42b), Sanders Plain is a grog-tempered, slipped, and undecorated type found widely across the Caddo area. Vessel forms include bowls (Figure 15a), carinated bowls, and narrow (Figure 15b-c) and wide-mouthed bottles. 


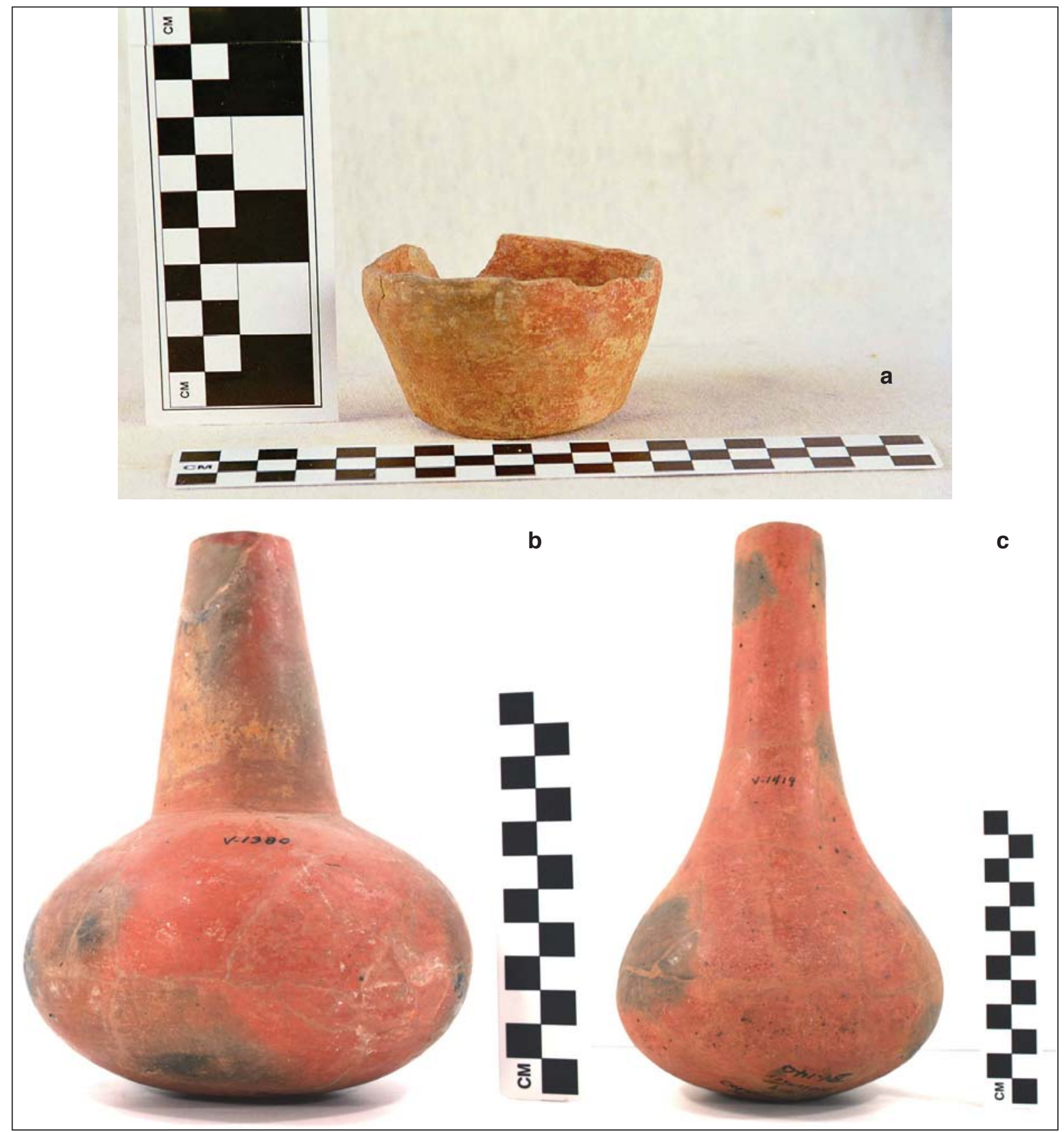

Figure 15. Sanders Plain vessels: a, bowl; b-c, bottles.

\section{Spoonbill Engraved}

Spoonbill Engraved was defined by Perttula et al. (2009) on the basis of several engraved bowls recovered from Middle Caddo period sites in the upper Sabine River basin. These vessels have interior thickened rims with upper and lower sets of hatched (3-4 hatched lines) engraved triangles. The apex of the upper and lower rows of triangles touch (Figure 16). 


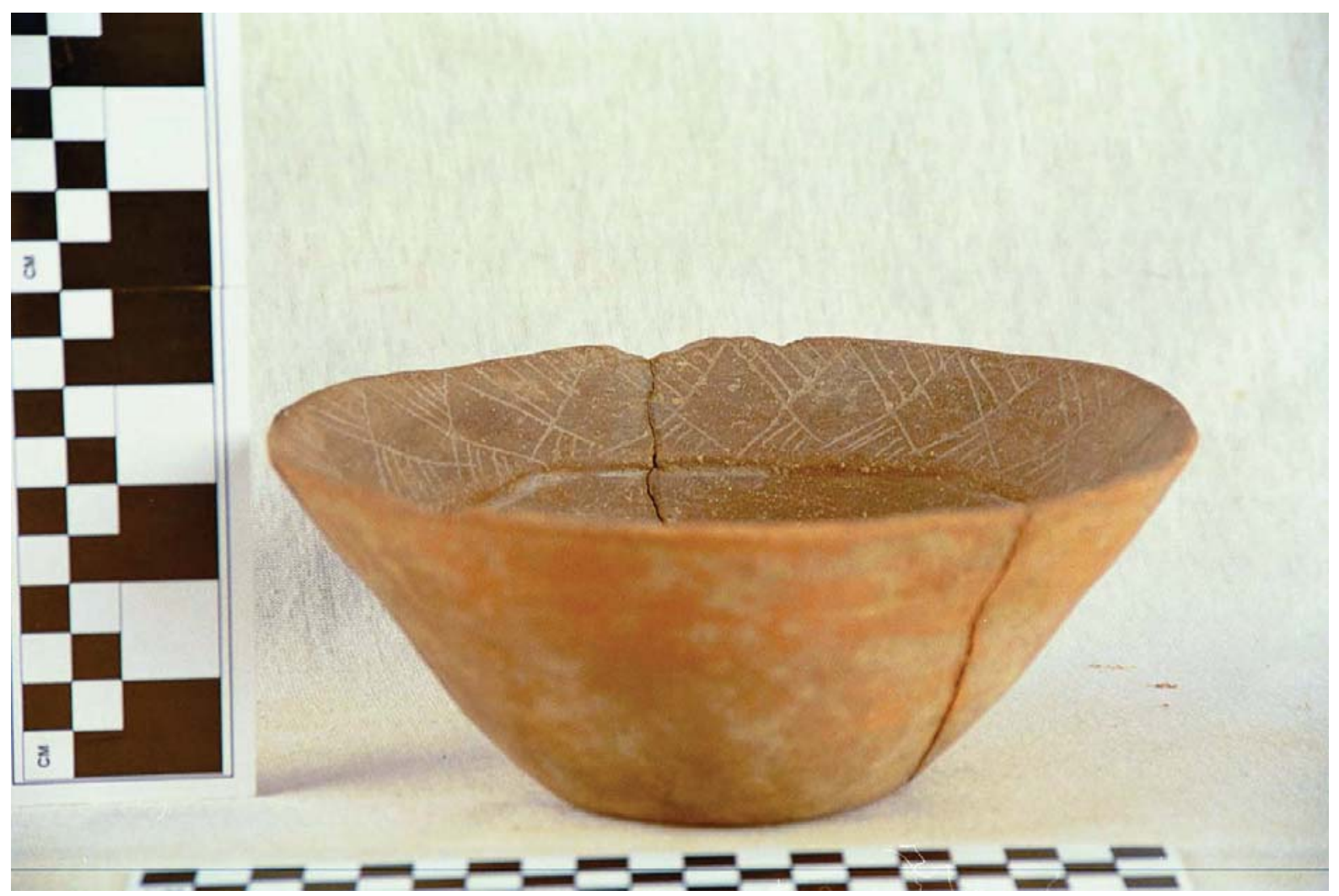

Figure 16. Spoonbill Engraved bowl.

\section{Spoonbill Plain}

This type has interior thickened rims on bowls, as with the type Spoonbill Engraved, but the rims are plain (Perttula et al. 2009:267) (Figure 17).

\section{Broaddus Brushed}

Broaddus Brushed is a utility ware type defined by Jelks (1965:122-125) from vessels and sherds recovered from Caddo sites in the Neches/Angelina River basins in the Lake Sam Rayburn area of East Texas. The type is tempered with grog and/or bone that occurs as jars with everted rims. The jars have horizontally brushed rims and vertically brushed bodies (Figure 18a-b). Occasionally, there are rows of punctations on the rim, with a row below the lip, a second row encircling the middle of the rim, and a third row at the rimbody juncture.

\section{Nacogdoches Engraved}

This is a fine ware type defined on the basis of vessels and sherds from the Washington Square Mound site (41NA49) in the Angelina River basin (Hart 1982; Hart and Corbin 1984). Sherds of the type have also been identified in Middle Caddo ceramic assemblages in the mid-Sabine River basin.

The type incorporates scroll and circle and concentric circle decorative modes (Hart 1982:Figure 3-4) on bottles, carinated bowls, and bowls (Figure 19a-d). Between the scrolls and concentric circle elements are 


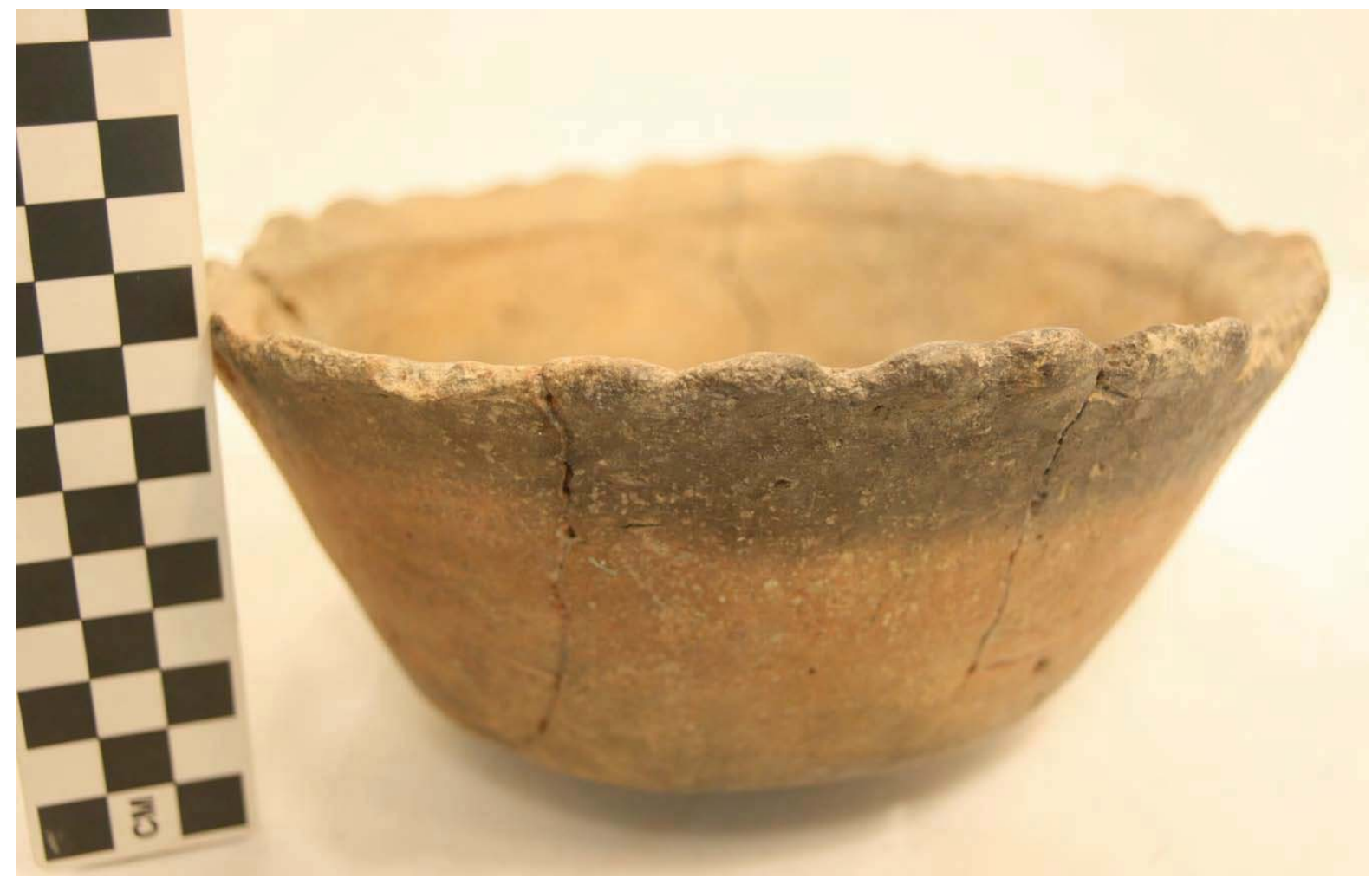

Figure 17. Spoonbill Plain bowl.
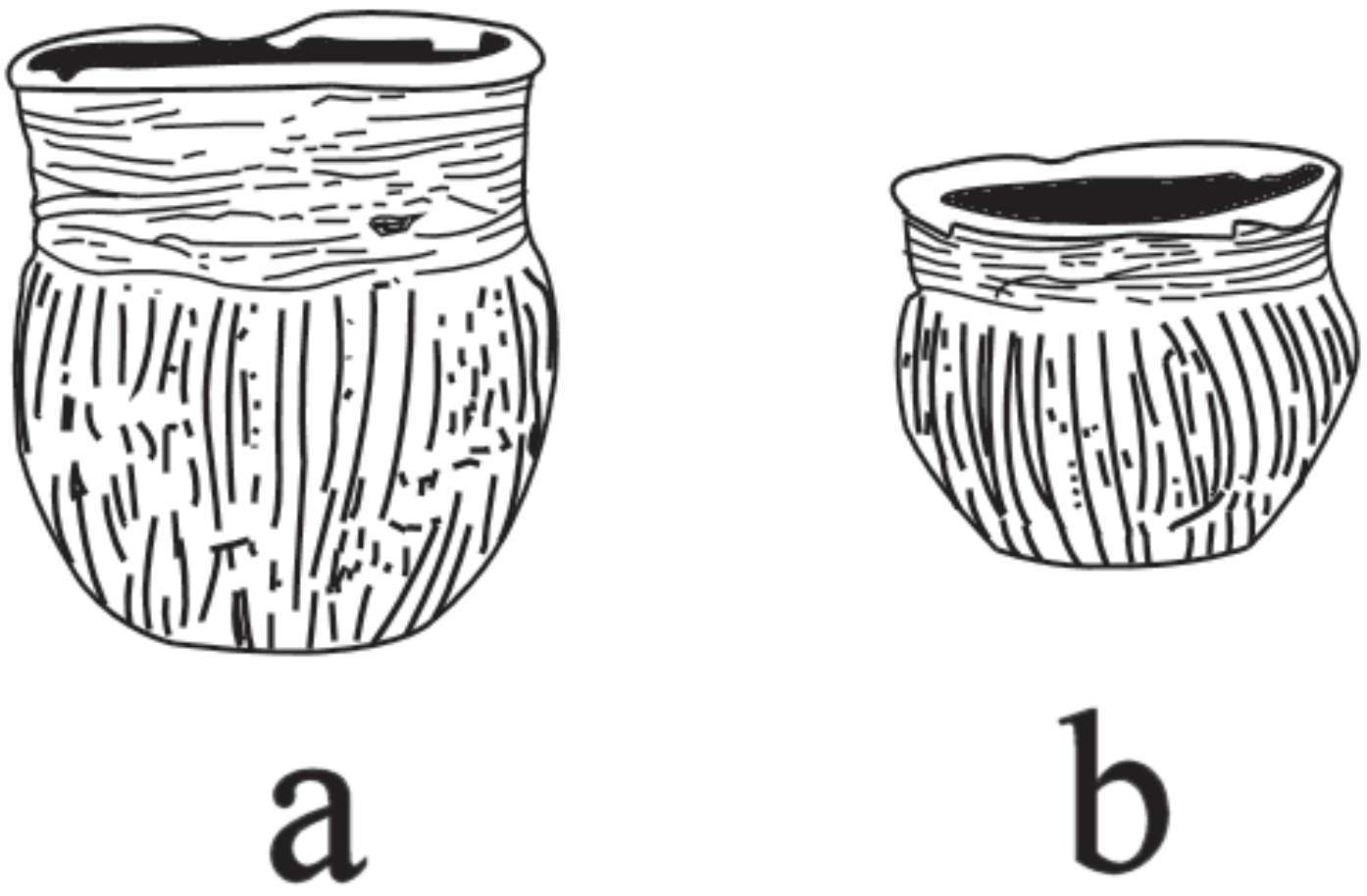

Figure 18. Broaddus Brushed jars (after Jelks 1965:Figure 62a-b). Drawings by Lance Trask. 


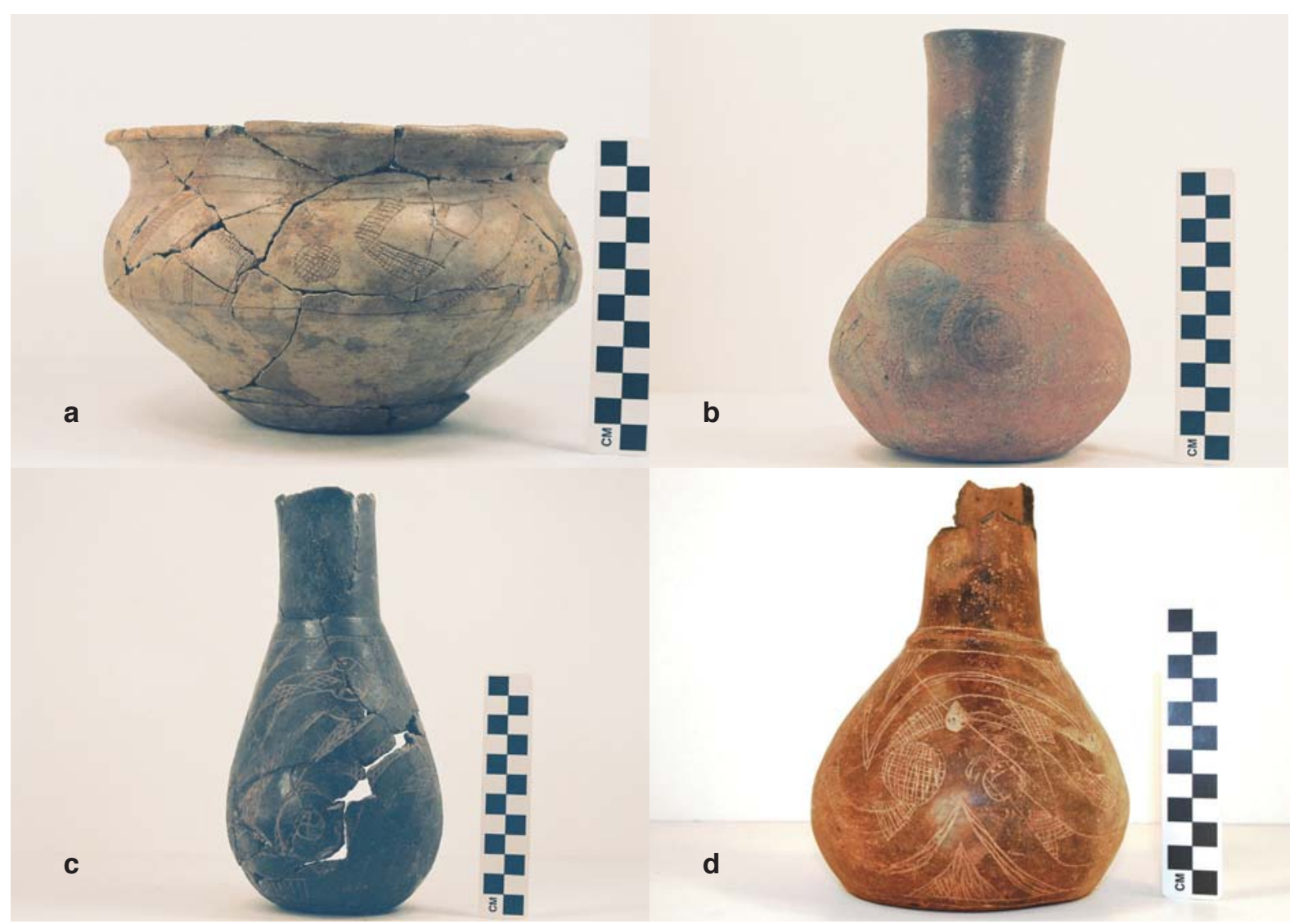

Figure 19. Nacogdoches Engraved vessels: a-c, Washington Square Mound site (41NA49); d, Harold Williams site (41CP10).

fill elements that are comprised of hatched triangles, narrow cross-hatched bands, hooked arms, and small circles with a central dot (Hart 1982:Figure 3-4). Examples of Nacogdoches Engraved bottles from sites in the Angelina, Sabine, and Big Cypress basins also are decorated with engraved rattlesnake motifs (Figure 19c-d; see Walters 2006; Gadus 2013:Figure 8).

\section{Pineland Punctated-Incised}

The Pineland Punctated-Incised type was defined by Jelks (1965:119-122 and Figure 61a-g) from a series of sites at Lake Sam Rayburn in the Neches-Angelina river basins. Pineland Punctated-Incised is a grog and/or bone-tempered utility ware, and occurs primarily as beaker-shaped jars as well as ollas and deep bowls. The vessels have concentric, triangular, rectangular, and curvilinear incised zones on the rim filled with tool punctations (Figure 20). Ollas and bowls have design elements on the vessel bodies (see Jelks 1965:Figure 61d, g).

\section{Reavely Brushed-Incised}

This utility ware type has been defined from jars and jar sherds recovered from the Washington Square Mound site (Hart 1982:63-65 and Figure 3-9). Rims tend to have a horizontal brushing element, sometimes with single rows of punctations at the top and bottom of the rim (var. Raguet). Vessel bodies primarily include vertical brushing divided into panels by appliqued fillets, vertical rows of punctations, or vertical incised lines. Other examples have diagonal, horizontal, or curvilinear brushed panels (Figure 21a-d). 


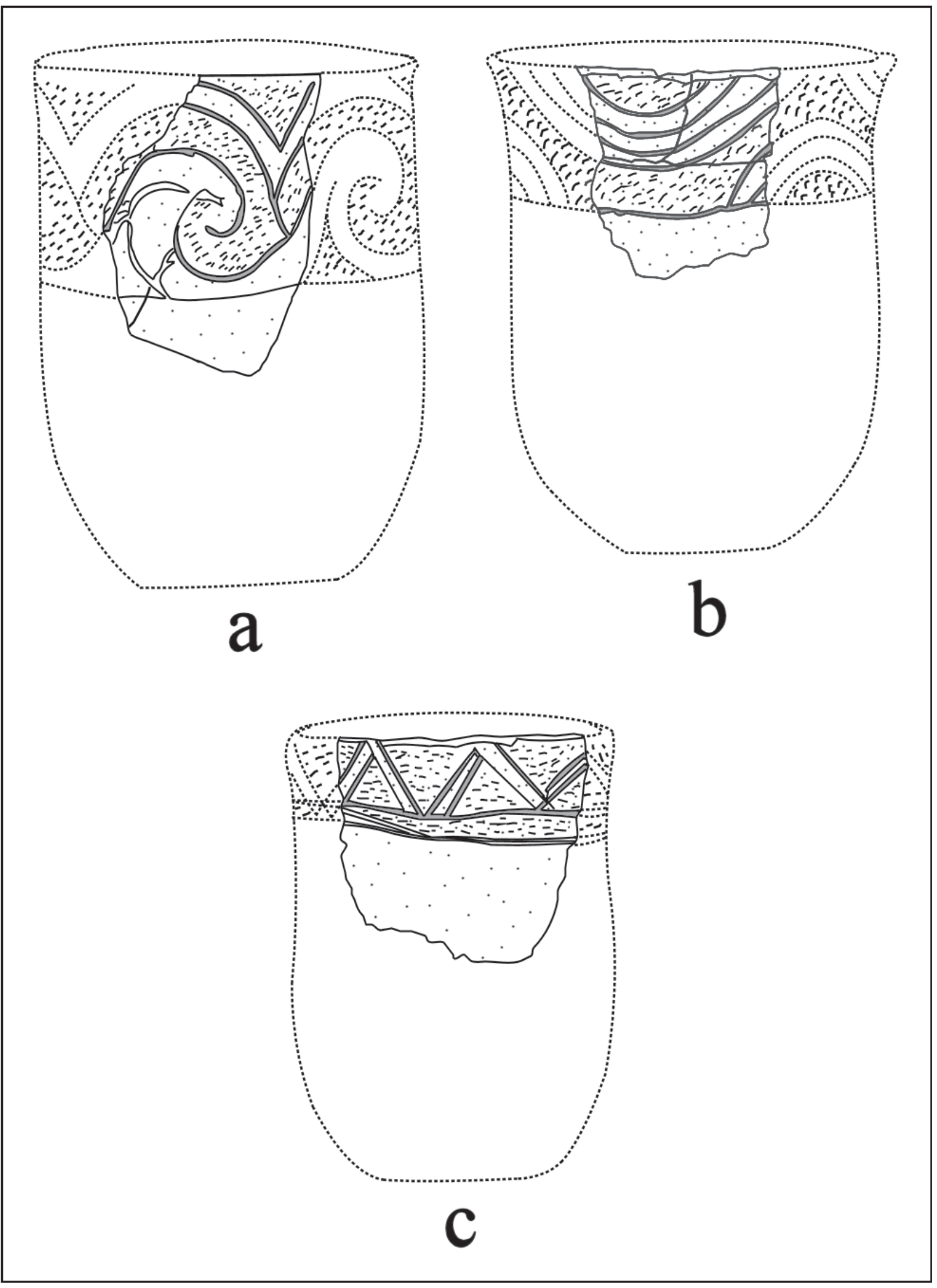

Figure 20. Pineland Punctated-Incised vessels and decorative elements (after Jelks 1965:Figure 61). Images prepared by Lance Trask. 


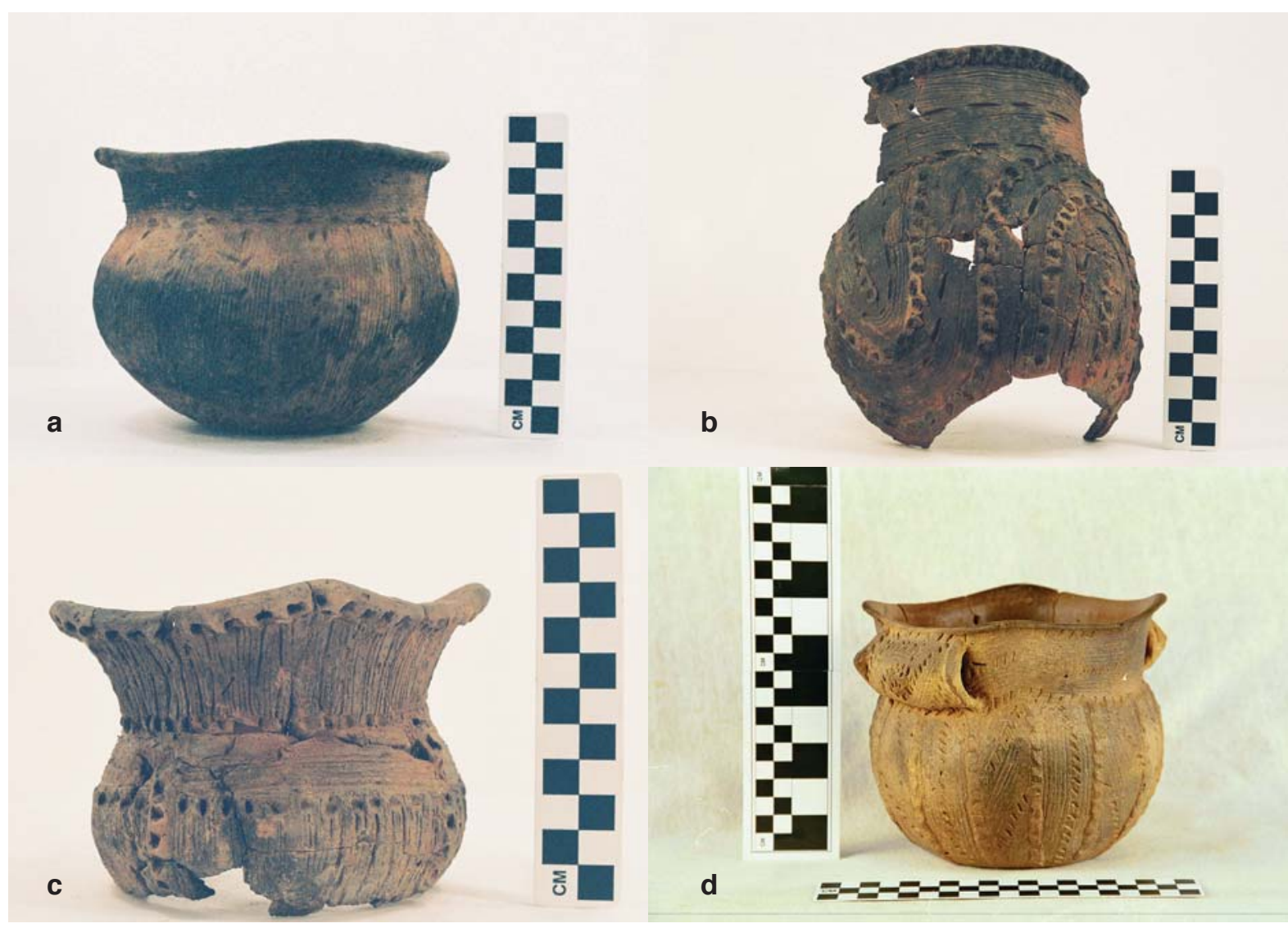

Figure 21. Reavely Brushed-Incised vessels: a-c, Washington Square Mound site (41NA49); d, Redwine site (41SM193).

\section{Tyson Engraved}

Middlebrook (1994:24 and Figure 3) defined Tyson Engraved based on carinated bowls from the Tyson site (41SY92) on Attoyac Bayou in western Shelby County in East Texas. Other vessels of this type have been recovered and identified from several other sites in central and northern Shelby County. Tyson Engraved vessels have "half column[s] with straight or biconcave sides covered by two widely spaced parallel semicircle lines, ... a "fat" negative S-shaped scroll, and ... sets of 1-4 attaching lines that connect the other two elements to each other or to a basal line" (Middlebrook 1994:24) (Figure 22).

\section{Washington Square Paneled}

Washington Square Paneled vessels and sherds have been identified at ancestral Caddo sites in the Angelina and mid-Sabine River basins, and the type was defined by Hart (1982:71-73 and Figure 3-12). The type occurs on carinated bowls with rectilinear engraved or incised panels, including interlocking horizontal scrolls with hatched or punctated brackets as well as punctated rows at the top and bottom of the panels (Figure 23a-b). One Washington Square Paneled vessel from the Washington Square Mound site has vertical punctate-filled columns divided by horizontal rows of punctations (Hart 1982:Figure 3-12a). 


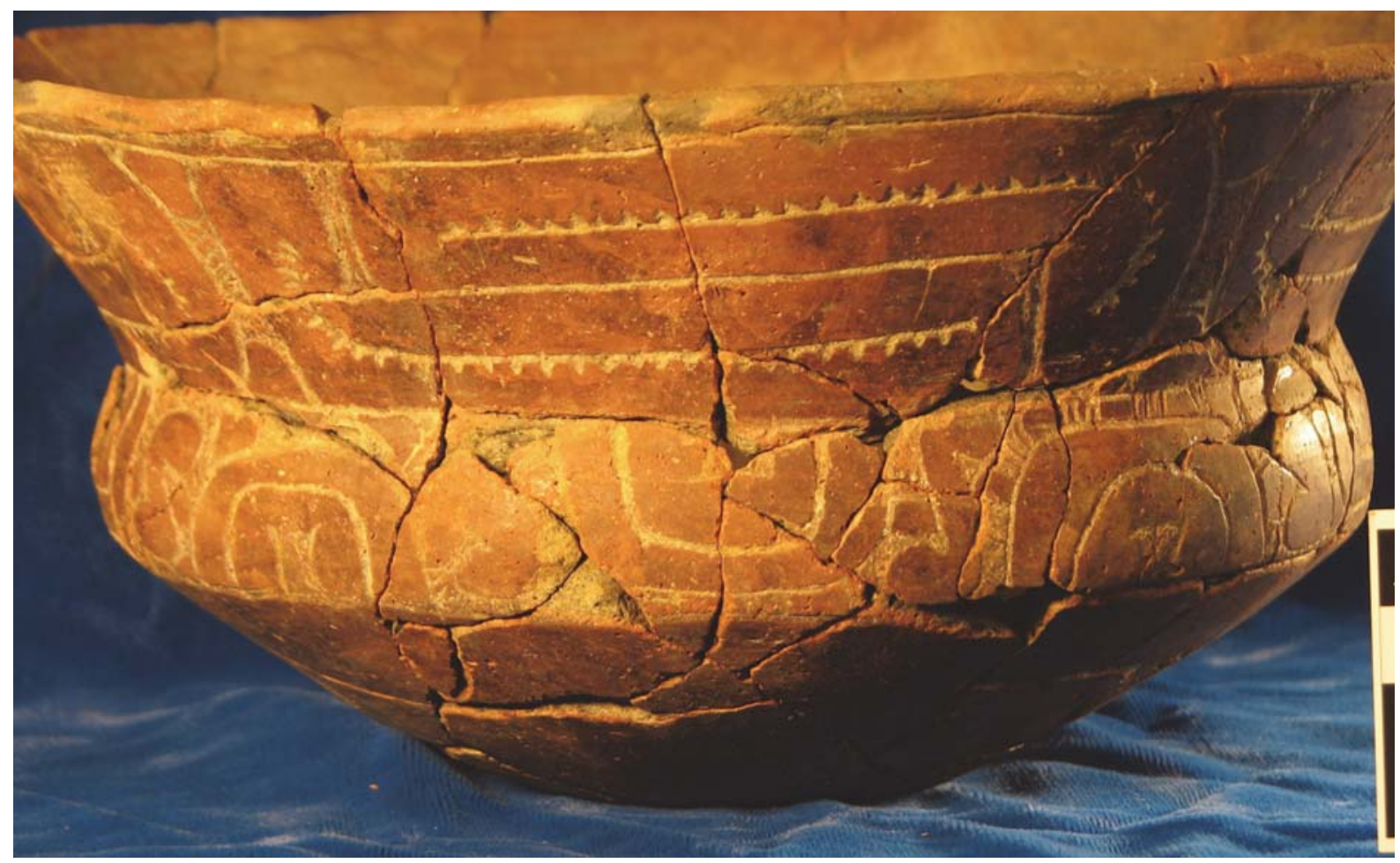

Figure 22. Tyson Engraved vessel from the Tyson site (41SY92). Image courtesy of Tom Middlebrook.

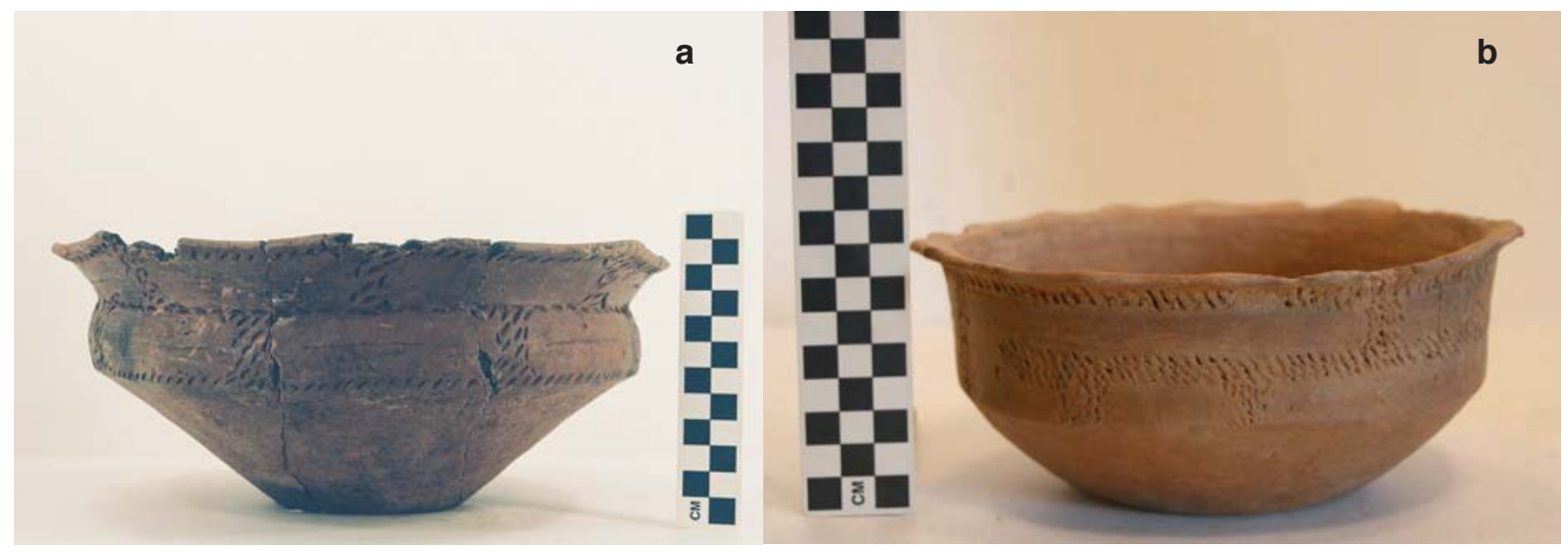

Figure 23. Washington Square Paneled vessels: a, Washington Square Mound site (41NA49); b, Smith County.

\section{Late Caddo}

\section{Anglin Corn Cob Impressed}

Anglin Corn Cob Impressed sherds were defined in the assemblage of 16th and 17th century utility wares from the Tuinier Farm (41HP237) and Anglin (41HP240) sites in the Stouts Creek basin in the upper Lake Fork Creek drainage (Perttula 2009). The Anglin Corn Cob impressed rim and body sherds are marked by roughly parallel or horizontal rows of impressions created by rolling a corn cob across the wet surface of an unfired jar (Figure 24). Corncob impressed pottery had been previously identified in the ceramic sherd assemblage at the Spoonbill site (41WD109) in the Lake Fork Creek basin (Bruseth and Perttula 1981:Table 5-8 and 82), where it was dubbed "Corn Cobb Incised." 


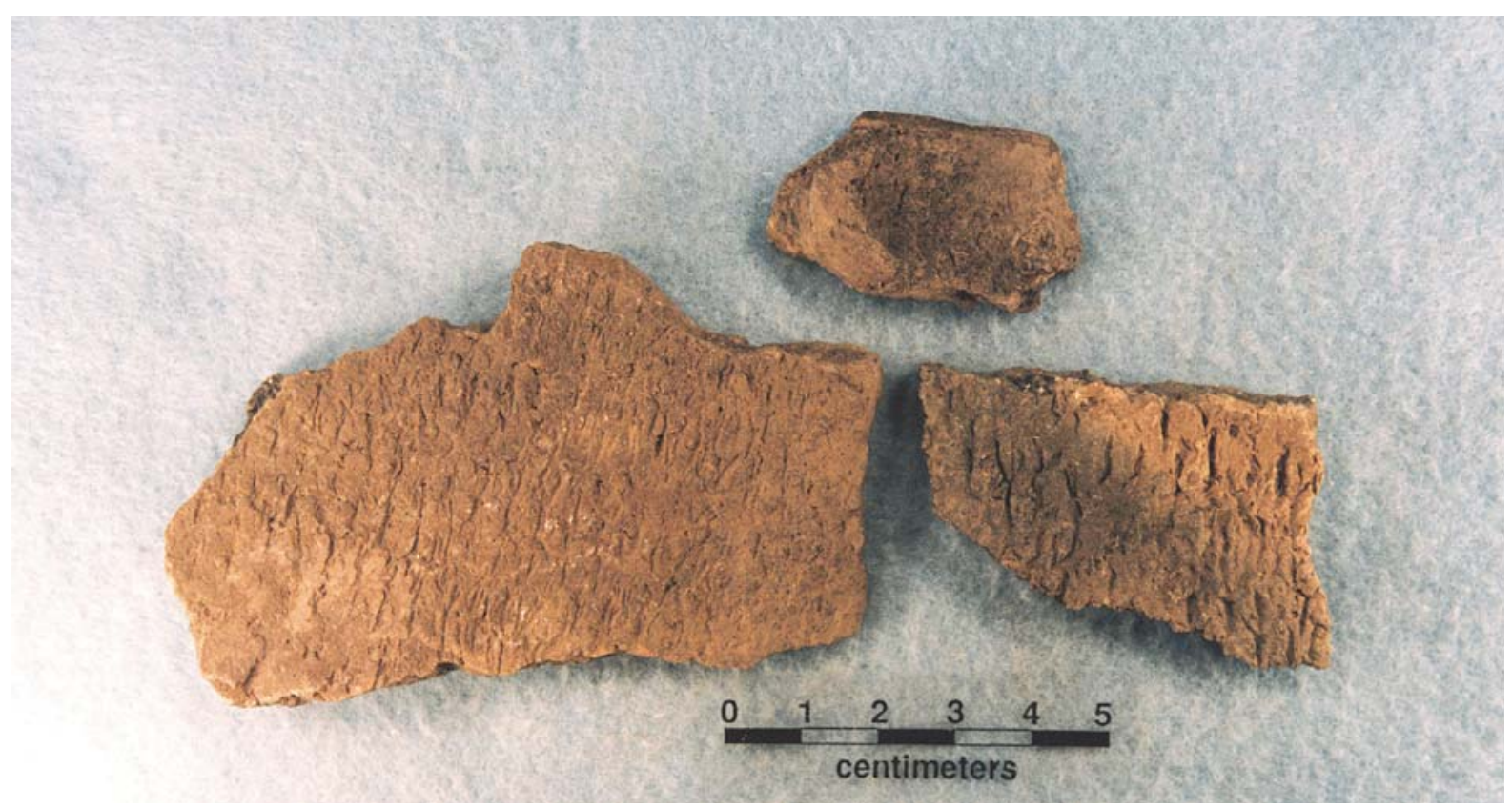

Figure 24. Anglin Corn Cob Impressed sherds from the Anglin site (41HP240).

\section{Clark Engraved}

Perino (1994:29) defined Clark Engraved on the basis of a series of carinated bowls from the Rowland Clark site (41RR77) on the Red River in contexts that date to ca. A.D. 1300-1500. The engraved motifs have panels and horizontal or slanted scrolls arranged around circle and oval elements (Figure 25).

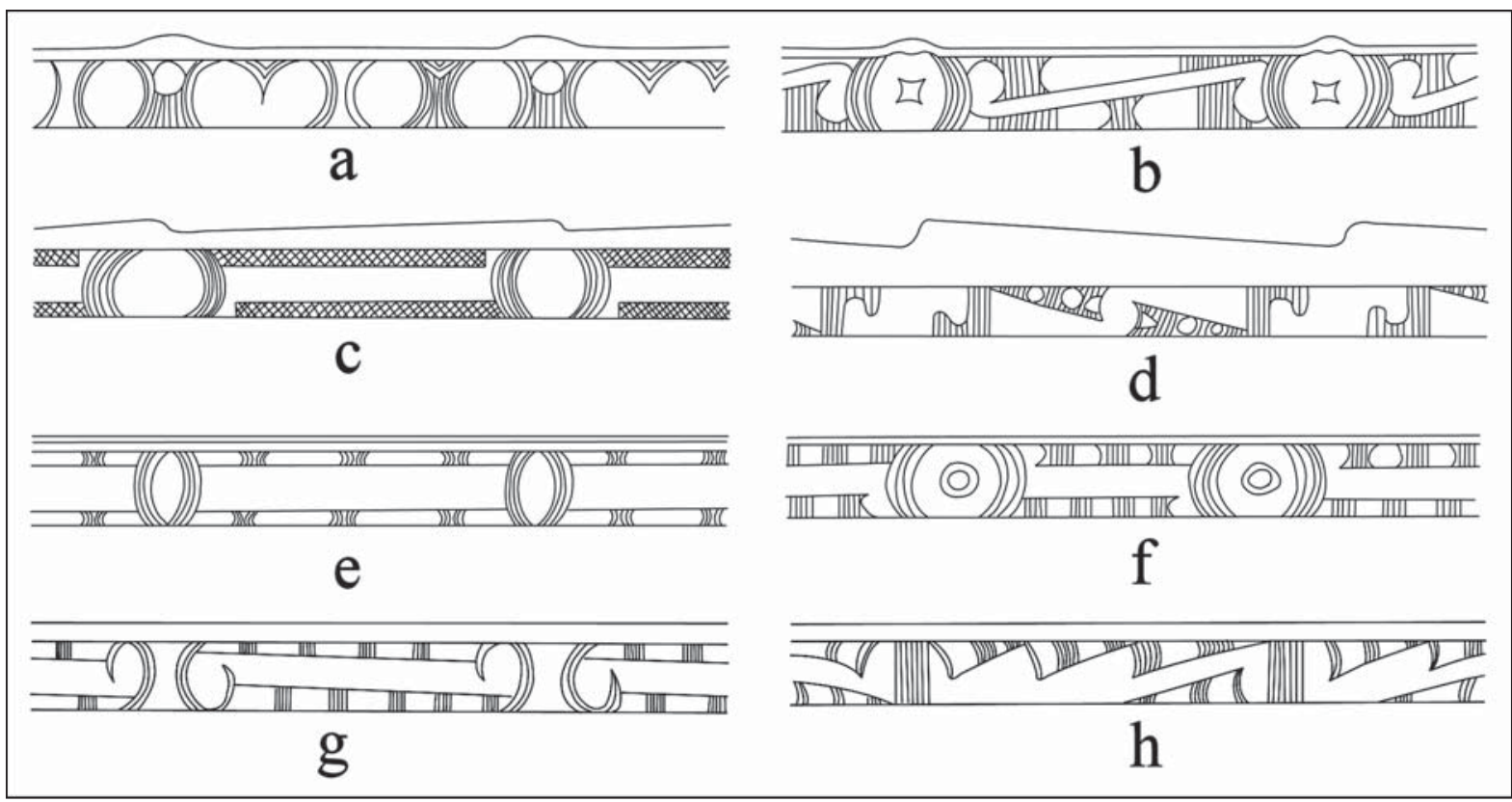

Figure 25. Decorative elements on Clark Engraved vessels from the Rowland Clark site (after Perino 1994). 


\section{Emory Punctated-Incised}

Although initially described from the sherd and vessel assemblage recovered at the Womack site (41LR1) on the Red River by Harris et al. (1965:299), the type now known as Emory Punctated-Incised was defined in print by Story et al. (1967:136-138) from sherds recovered at the $18^{\text {th }}$ century Gilbert site. The type occurs in both prehistoric and historic Caddo contexts, based primarily on a large assemblage of McCurtain phase vessels from sites on the Red River in East Texas and Southeast Oklahoma (see Perino 1981, 1983, 1994).

According to Story et al. (1967:137), Emory Punctated-Incised occurs as jars tempered with sand, sandshell, sand and grog, or sand and bone. "Some vessels have only punctations arranged into one to four rows around the vessel, usually just below the lip. If brushing is present, it may occur almost anywhere on the vessel, from the lip to the base. If incising is present, it usually consists of straight to slightly curved lines extending from below the rim to the base or to about the middle of the body. Punctations are often combined with either incising or brushing" (Story et al. 1967:137). Red River varieties of Emory Punctated-Incised commonly also include appliqued elements on the vessel bodies (Figure 26) as well as horizontal row of punctates on the rim.

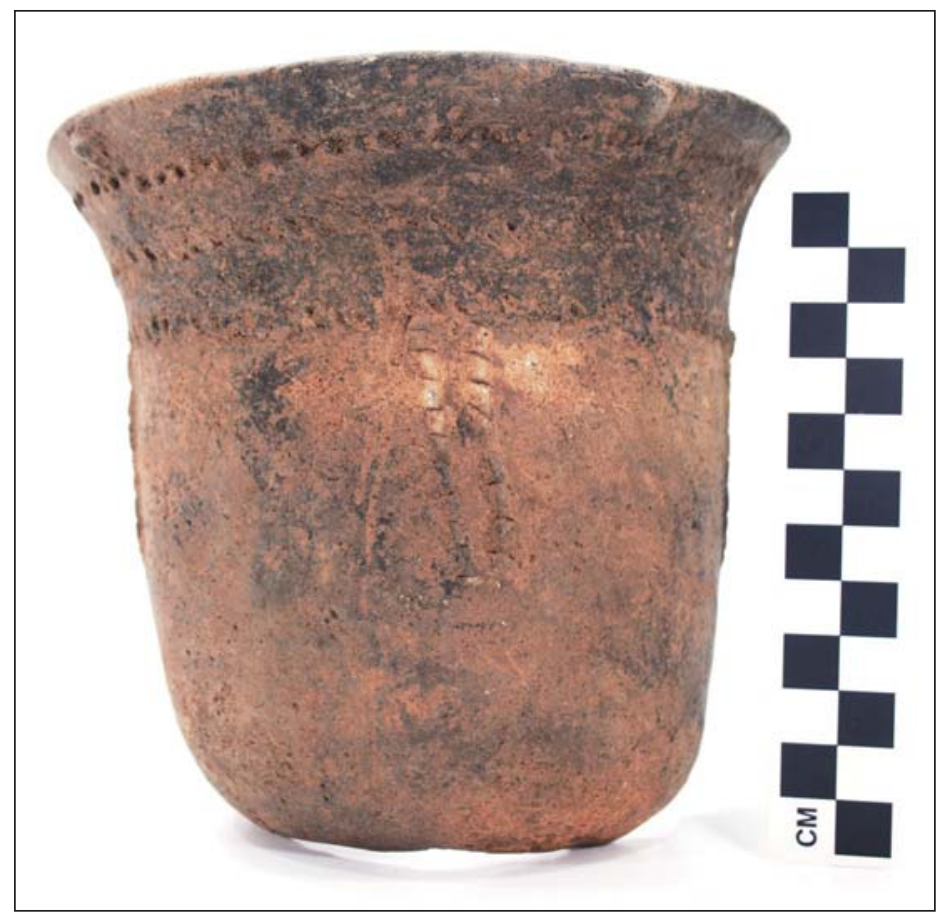

Figure 26. Emory Punctated-Incised jar from the Sam Kaufman site (41RR16).

\section{Fair Plain}

Fair Plain is a distinctive undecorated squat-bodied bottle with a long neck (Figure 27; see also Perttula et al. 2011:Figures 6-27 and 6-62a). These are found in Frankston phase contexts in sites in the upper Neches River basin. There is also an engraved variety of this type from the Mrs. J. M. Cook site (41AN1, Perttula et al. 2011:Figure 6-38c). 


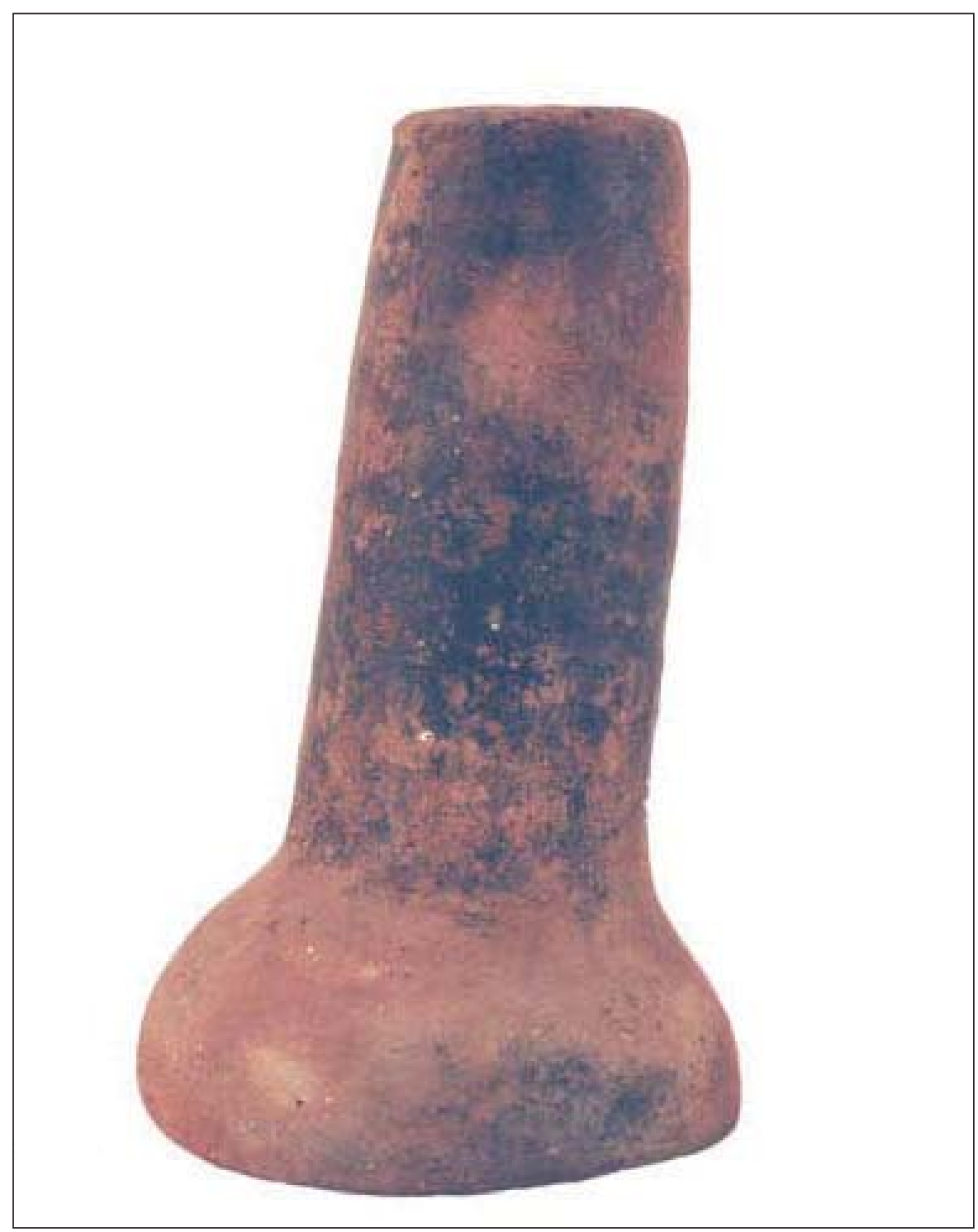

Figure 27. Fair Plain bottle from 41CE25.

\section{Gardener Punctated}

Gardener Punctated is a utility ware found in Titus phase contexts in East Texas (Perttula et al. 2014). These vessels have a distinctive exterior thickened rim strip that has a row of triangular-shaped tool punctates on the rim strip, just below the lip (Figure 28). At least one other site at Lake Bob Sandlin has Gardener Punctated sherds, but its distribution within the Big Cypress Creek basin remains poorly defined.

\section{Gilmer Engraved}

Parsons (2011:374-375) defined this Late Caddo type on the basis of vessel batches from the Rookery Ridge site (41UR133) and other contemporaneous sites in the Little Cypress Creek basin. According to Parsons, this type occurs on carinated bowls and compound bowls with narrow inverted rims or shoulders. The engraved design consists of narrow panels or bands that are divided by vertical excised, hatched, or cross-hatched elements. The bands are either left plain or include short horizontal or vertical lines at their centers (Figure 29a-c). 


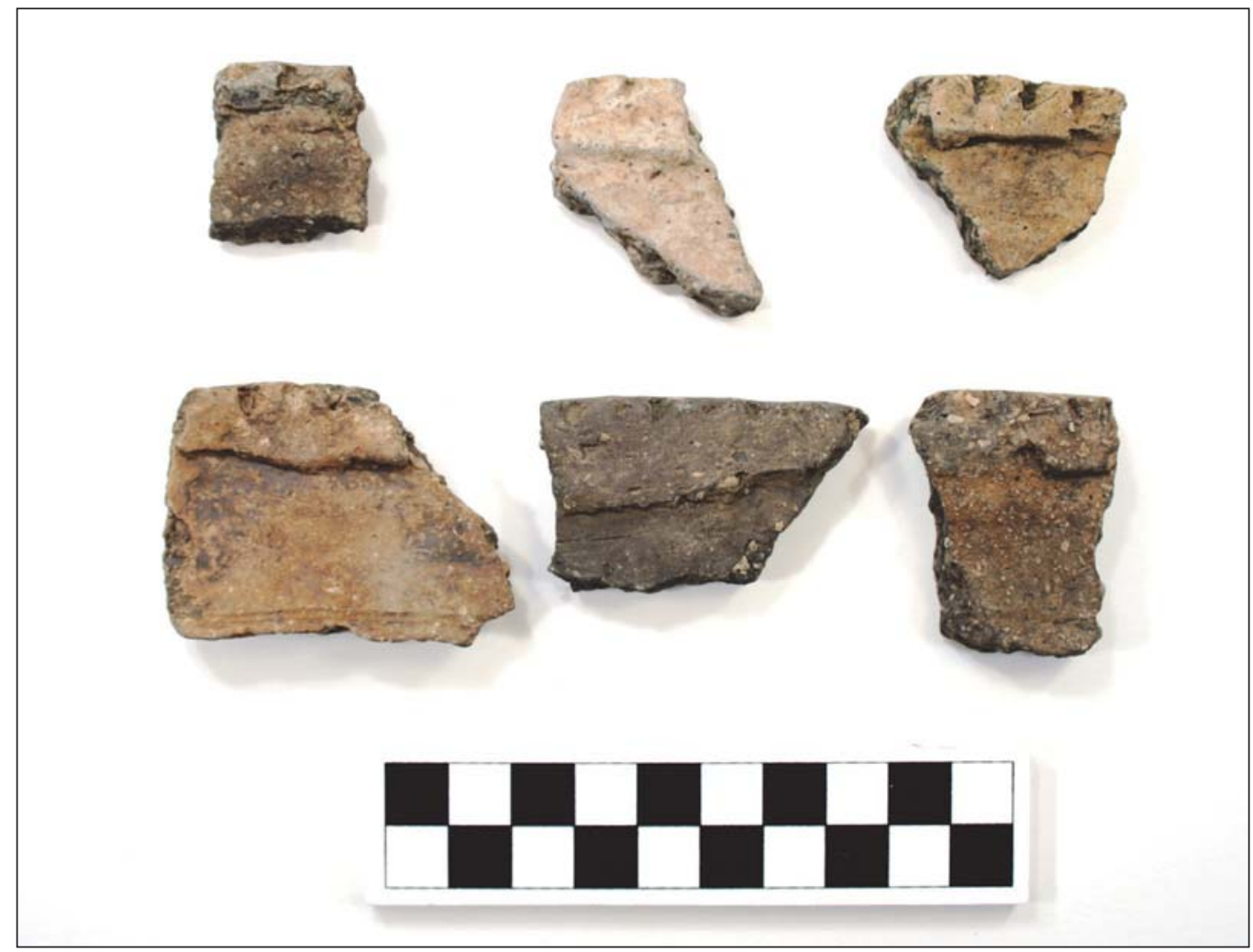

Figure 28. Gardener Punctated rim sherds from the Gardener site (41CP55).

\section{Hood Engraved}

Hood Engraved vessels are effigy vessels with effigy heads and tab tails, as well as horizontal engraved lines encircling the rim (Figure 30). These vessels are found in both Frankston and Allen phase contexts, but only Hood Engraved, var. Allen includes tail rider elements attached to the vessel lip. Hood Engraved, var. Cook also has engraved pendant triangles as a decorative element.

\section{Hume Plain}

This type is comprised of plain cylindrical bottles with short necks (Figure 31; see also Perttula et al. 2011:Figures 6-27a-b, 6-48d, and 6-53c). The same vessel form occurs in the Hume Engraved type.

\section{Johns Engraved}

Johns Engraved is a Titus phase ceramic type found at several sites in the Big Cypress Creek basin. It is distinctive in having sets of engraved bird bodies and heads on the vessel body of bottles and bowls, each upside down with the head (with a single eye and a beak) resting on the lower part of the body panel (Figure 32a-d). Between each of the engraved heads are engraved circles (with a smaller circle within it, resembling the eyes of the birds), and curvilinear hatched areas, some with hooked engraved lines that wrap around or connect with the bird beak and body. Within each of the bird bodies, and pendant from the neck, are engraved triangles with hatched or cross-hatched corners and a small central circle or bird eye (Turner 1978:86 and Figure 31; Perttula, Walters, and Nelson 2010). Johns Engraved bowls include sets of hooked engraved elements rather than the hooked beaks of engraved birds, otherwise the principal motif on Johns 


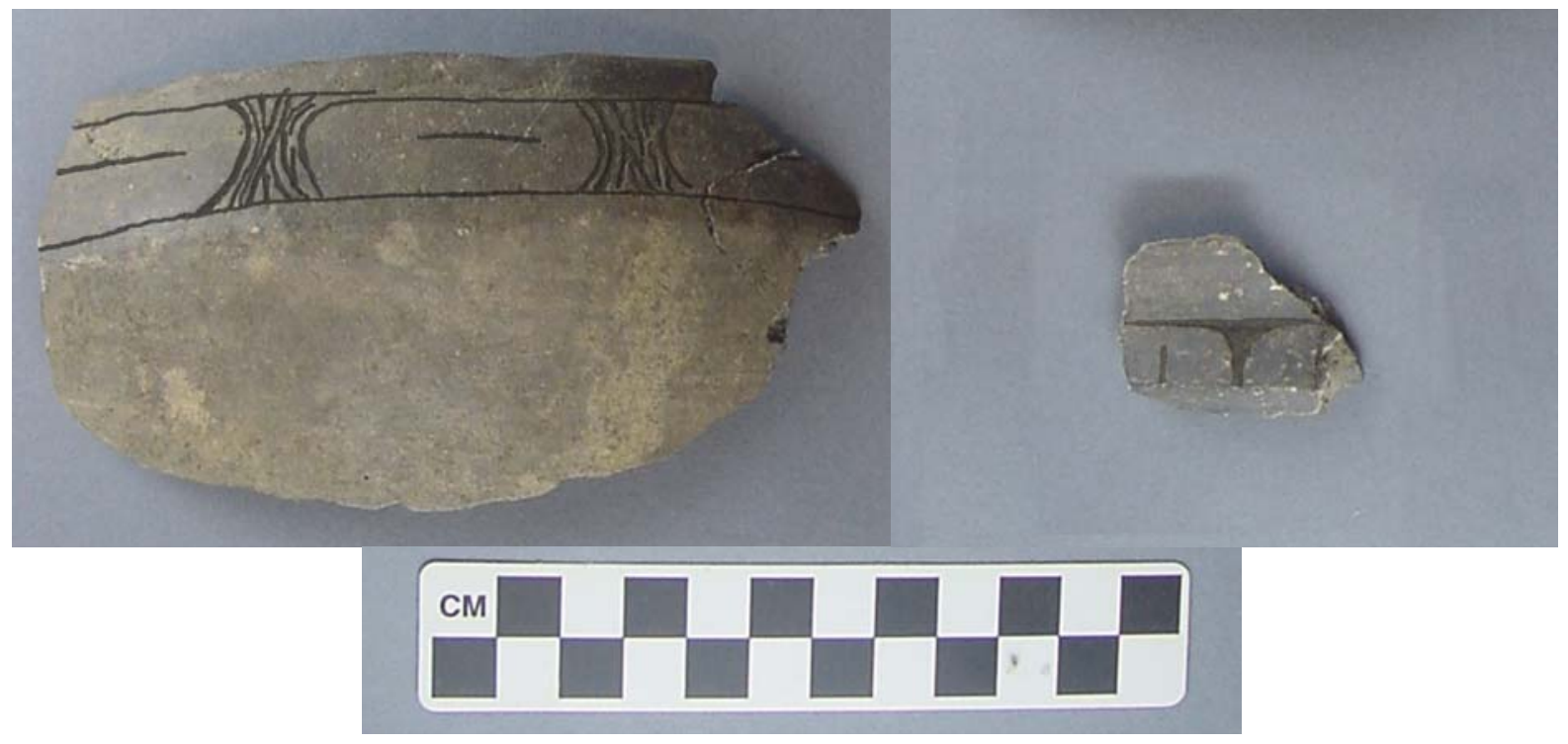

Figure 29. Gilmer Engraved rim sherds from the Rookery Ridge site (41UR33). Image from Parsons (2011:Figure 9-37c-e).

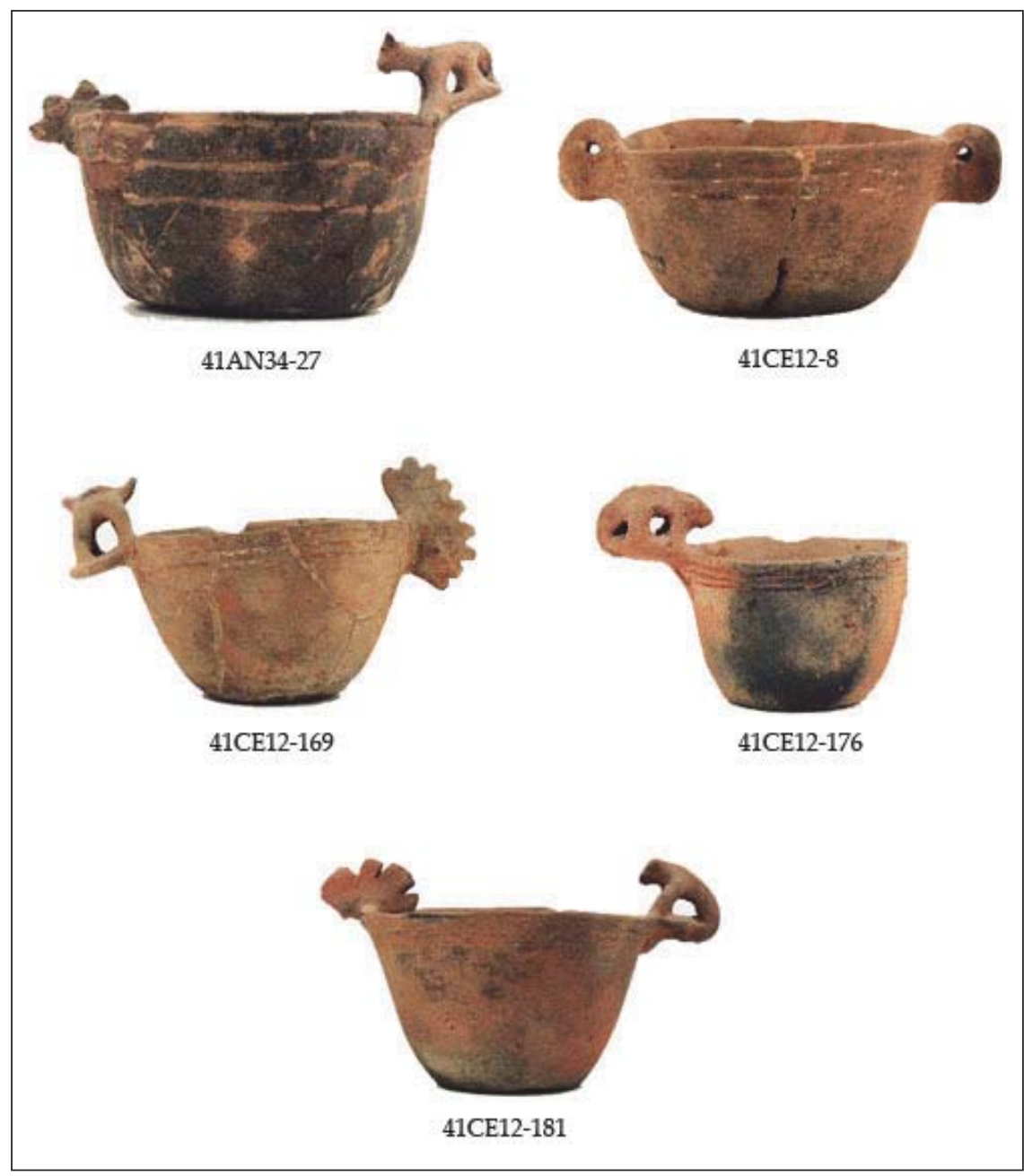

Figure 30. Hood Engraved effigy bowls from sites in the upper Neches River basin. 


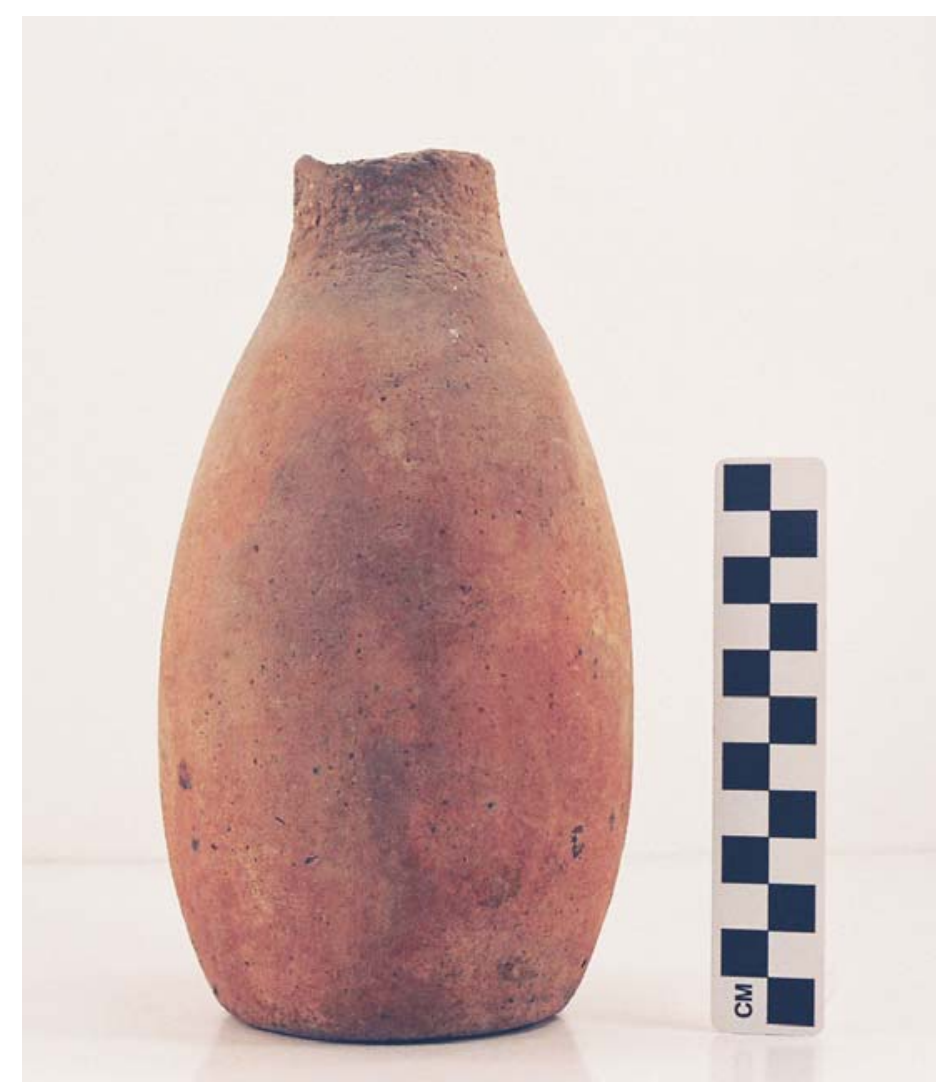

Figure 31. Hume Plain bottle from the upper Neches River basin.

Engraved vessels. One bowl from the Johns site (41CP12) with a hooked element has four horizontal engraved lines within it as well others that have within them a single horizontal engraved line as well as an engraved triangle with hatched corners (see Perttula, Walters, and Nelson 2010:Figure 98).

\section{Moore Noded}

This type consists of bowls that are covered or virtually covered with rows of appliqued nodes (Figure 33a-d). The name Moore Noded was first used by Lynn Howard with respect to noded vessels from various Red River Arkansas Caddo sites (Webb 1959:120), and Webb (1959:120 and Figure 122a-b) described and illustrated vessels of this type from the Belcher site on the Red River in Northwestern Louisiana. Moore Noded vessels have also been documented from East Texas Caddo contexts along the Red River, and in the Big Cypress and Sabine River basins.

\section{Mockingbird Punctated}

Mockingbird Punctated is a grog-tempered utility ware jar form found in Titus phase ceramic assemblages in the Big Cypress Creek basin (see Perttula et al. 1998). The rims are decorated with several rows of horizontal tool punctations, and the vessel body is commonly plain (Figure 34a). Some rim punctated jars of the Mockingbird Punctated type in Titus phase assemblages have vertically brushed bodies, or appliqued nodes along the rim-body juncture (Figure 34b), or vertical appliqued fillets on the vessel body. 

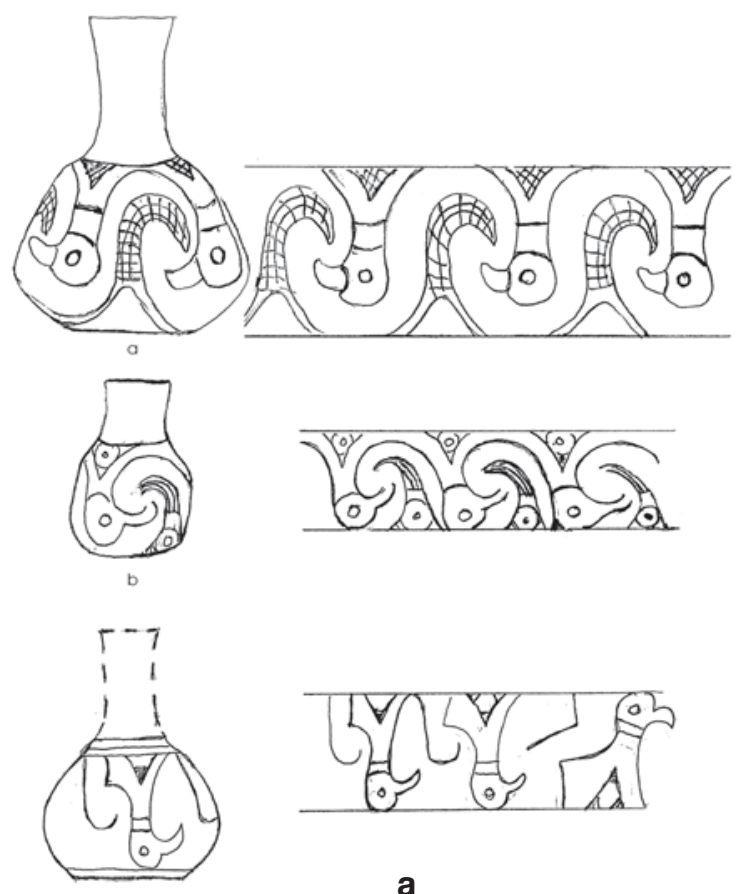

a

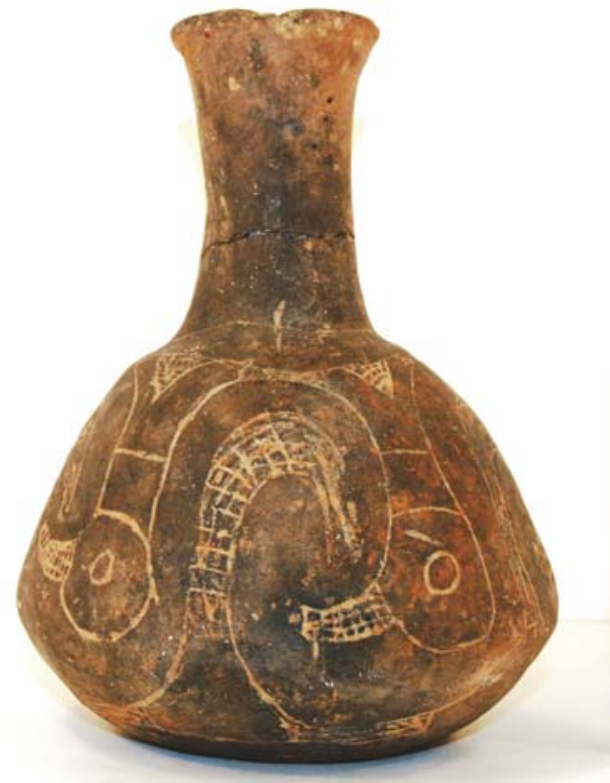

b
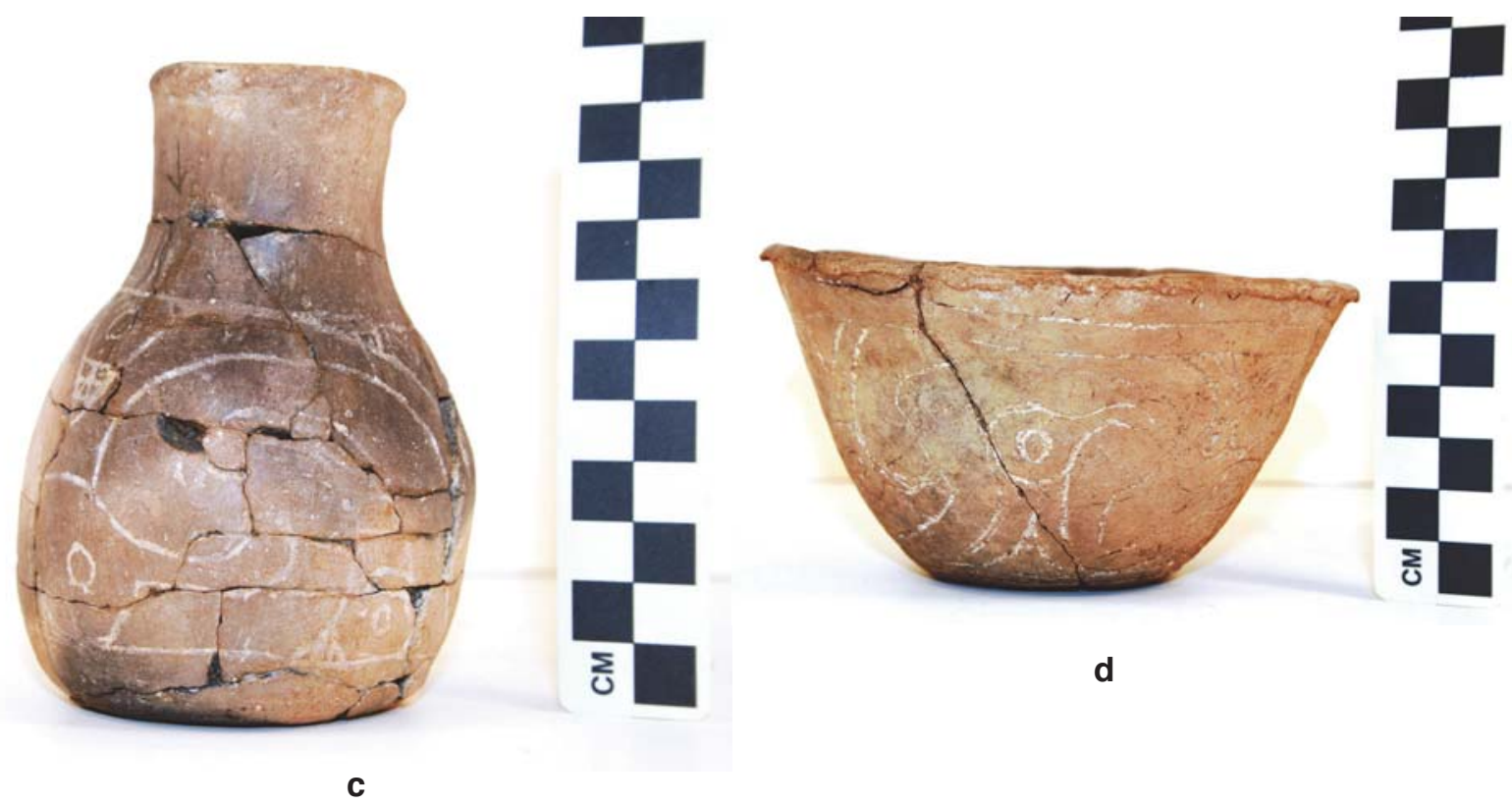

d

Figure 32. Johns Engraved: a, motifs on bottles (from Gadus 2013:Figure 9); b-c, bottles from the Johns site (41CP12); d, bowl from the Tuck Carpenter site (41CP5).

\section{Poynor Brushed}

Poynor Brushed is a Frankston phase ceramic type identified in the upper Neches River basin. The vessel form is comprised of globular vessels and carinated bowls - as commonly seen in Poynor Engraved vessels in this area-with brushed vessel bodies and brushed or plain rims (Figure 35; see also Perttula et al. 2011:246 and Figure 6-61b). 


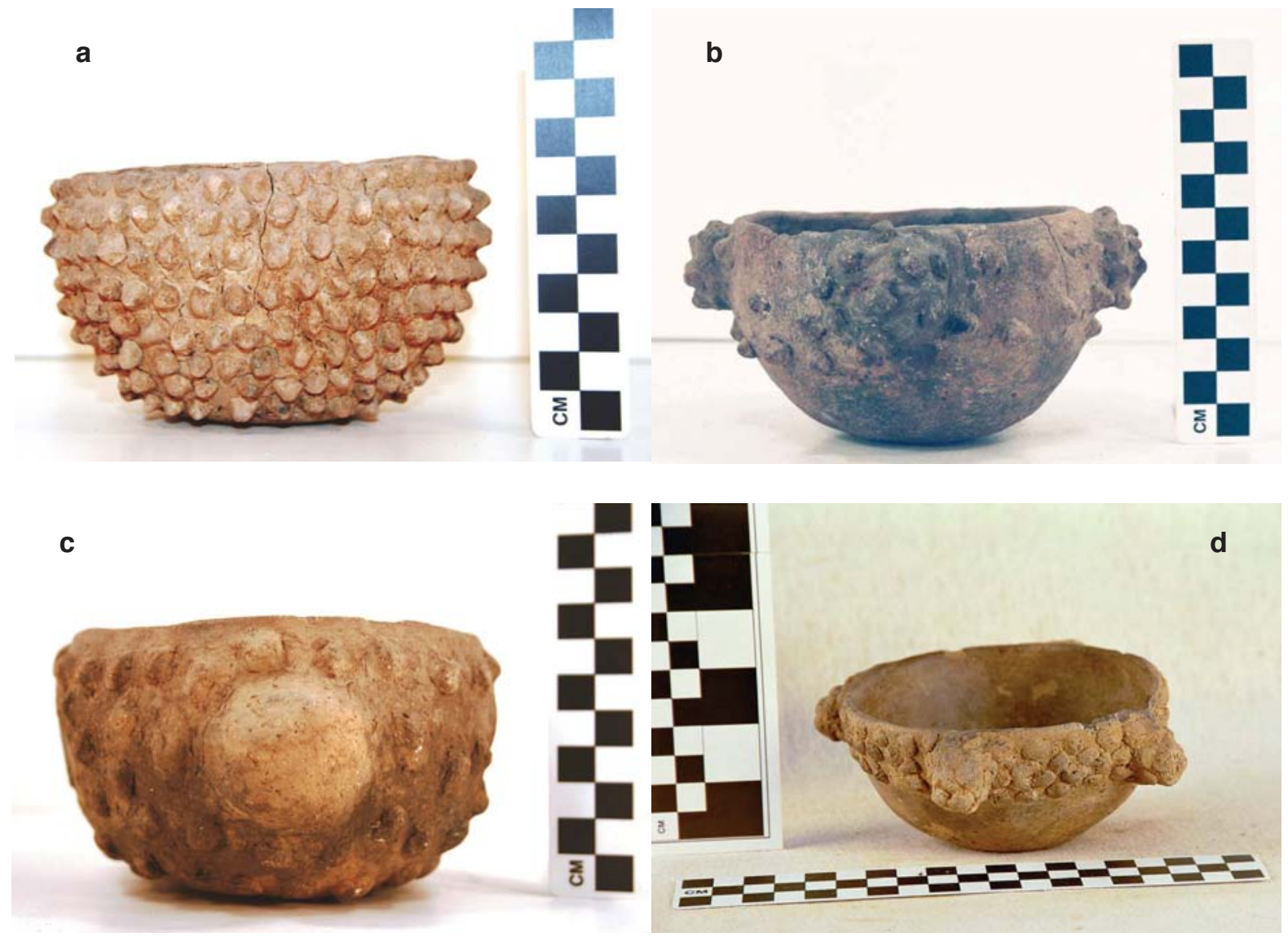

Figure 33. Moore Noded bowls from East Texas sites.
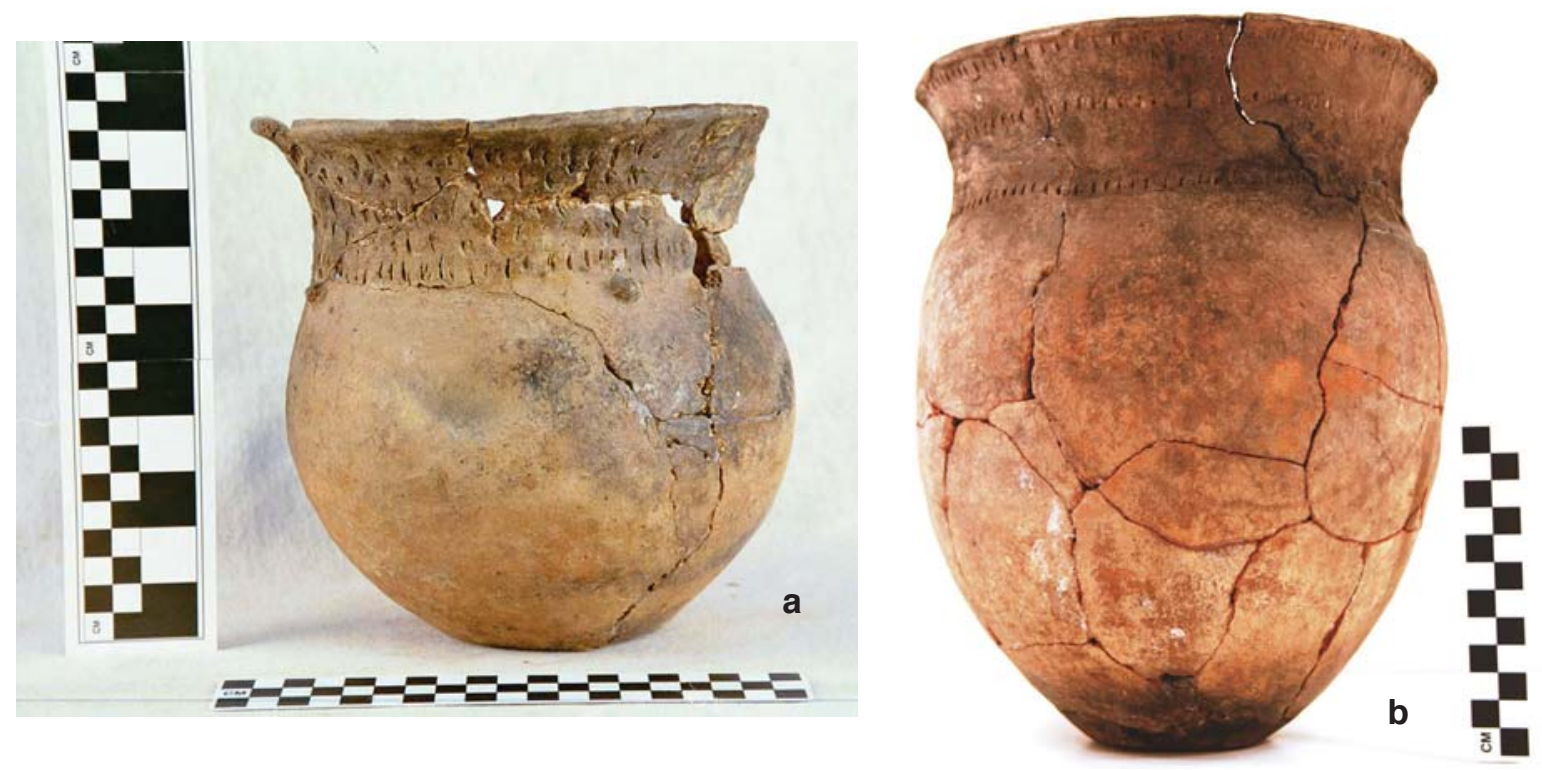

Figure 34. Mockingbird Punctated jars from Titus phase sites. 


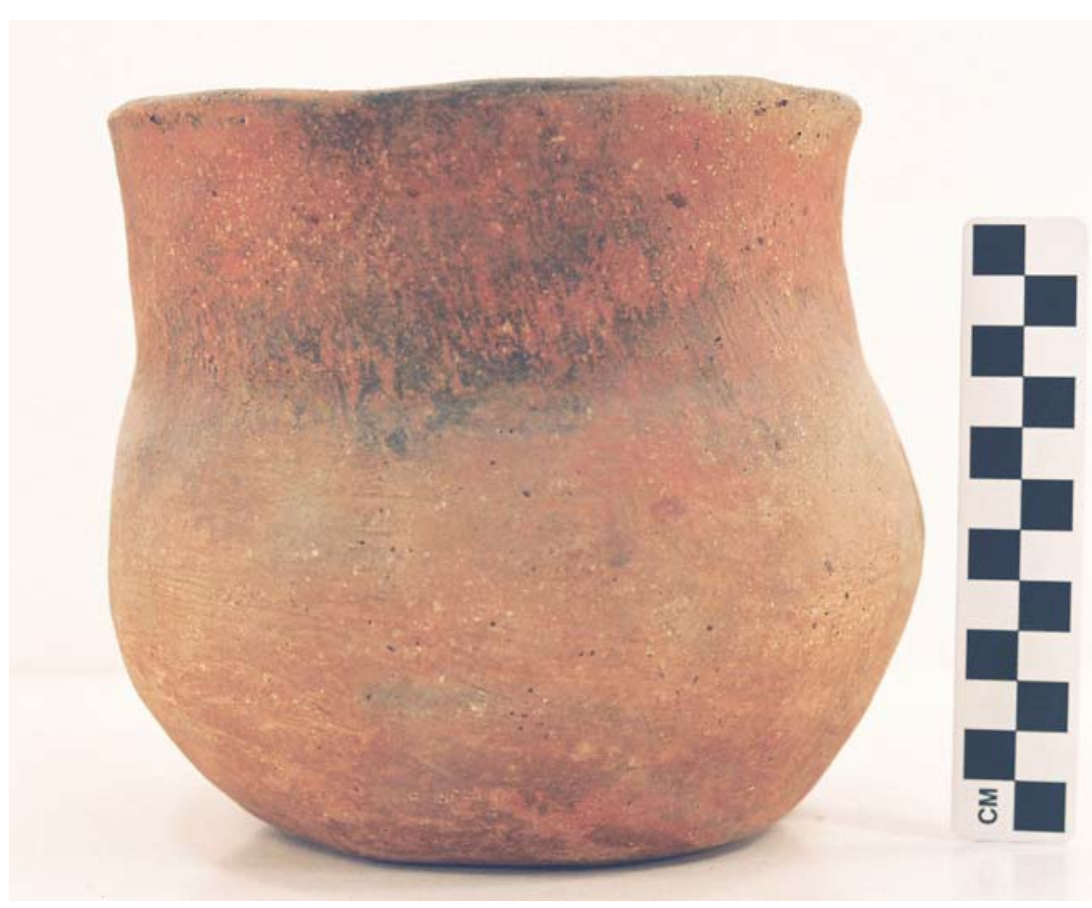

Figure 35. Poynor Brushed vessel from an upper Neches River basin site.

\section{Turner Engraved}

Turner Engraved is a new fine ware recognized in several Titus phase sites in the Big Cypress Creek basin. Turner Engraved, var. Turner includes an upper rim panel with two horizontal engraved lines. The lower rim panel has sets of alternating excised triangles. The alternating triangles in the set are regularly separated by a short diagonal line, while the sets are divided by a single short vertical engraved line (Figure 36a-c; see also Figure 10a); others simply have excised triangles on the lower panel (see Figure 10b). Turner Engraved, var. Horton vessels have an upper rim panel with two or three broadly-spaced horizontal engraved lines. The lower rim panel includes a series of large cross-hatched or hatched engraved triangles separated by engraved dashes just above the vessel carination (Figure 36d-f); others have excised triangles on the lower panel (see also Figure 10c-d). On each of the rim peaks is a negative oval outlined by excising (Perttula et al. 2012).

\section{Historic Caddo}

\section{Constricted Neck Punctated}

Gregory and Avery (2007:33,49-54) define this type as vessels with one or more rows of punctations around the neck of a constricted neck vessel (typically a jar) that lack incised lines below the row(s) of punctates. This distinction differentiates this type from Emory Punctated-Incised, which sometimes has parallel curvilinear incised lines below the rows of punctates on the vessel body. Vessels of this type have been identified in both Northwest Louisiana and East Texas historic Caddo sites (see Gregory and Avery 2007; Jackson et al. 2012).

\section{Darco Engraved}

Darco Engraved was initially identified by Jones (1968:161-163) from historic Kinsloe phase sites in the Sabine River basin. Jones (1968:163) noted its similarity in paste and decoration to Simms Engraved vessels, 

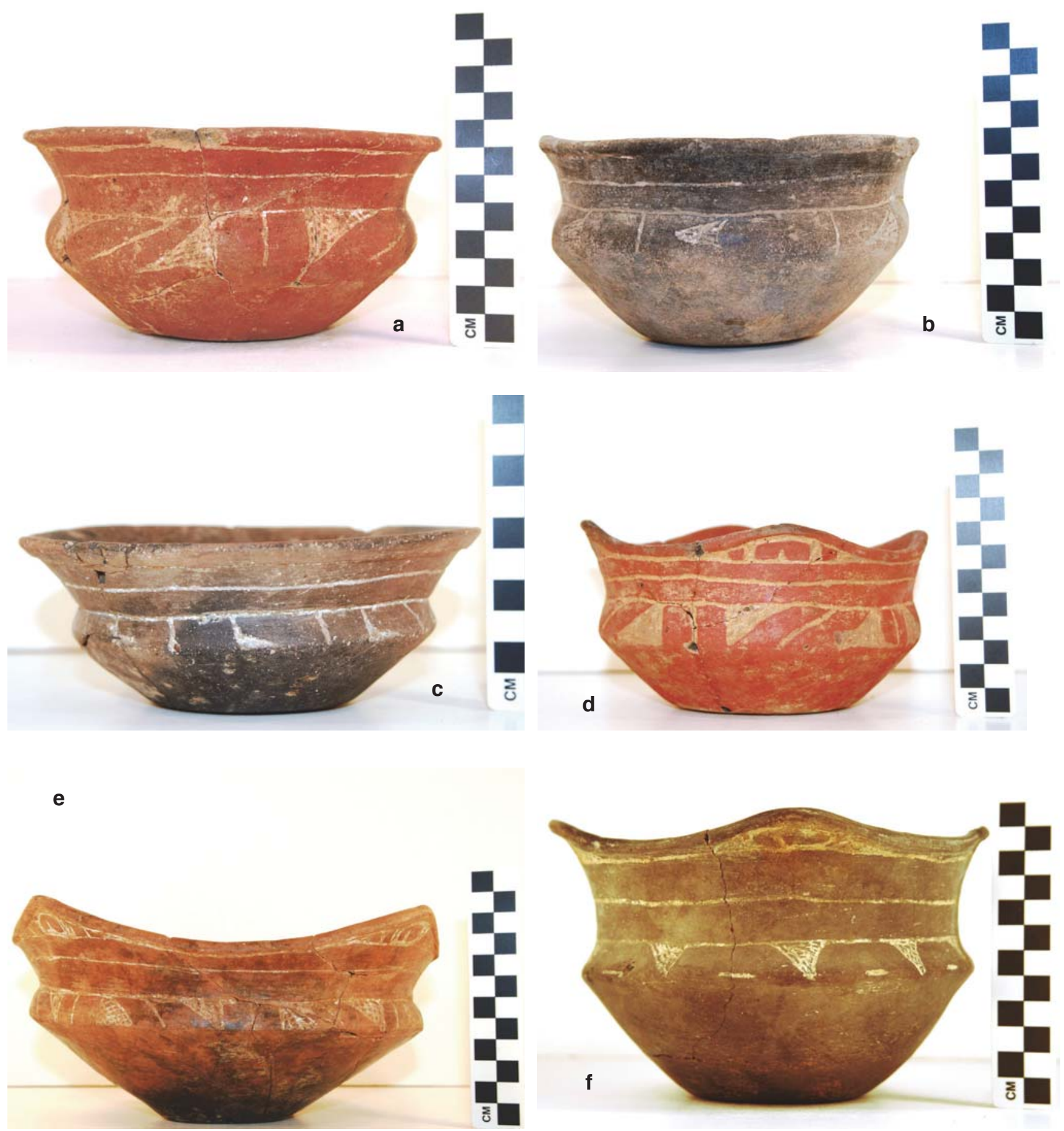

Figure 36. Turner Engraved vessels: a-c, var. Turner; d-f, var. Horton.

as Darco Engraved vessels were tempered with grog as well as shell, and were carinated bowls with a small rim panel (to which the decorative motif was confined) and an outflaring rim. Jones (1968:162) described the design as consisting of "from four to seven panels formed by "ticked" vertical, diagonal, and horizontal lines extending from a plain horizontal base line where the rim and shoulder meet." 
More recently, Perttula et al. (2010) have reclassified Darco Engraved as Simms Engraved, var. Darco. Vessels of this type and variety have notched lips and discontinuous engraved elements with downwardpointing tick marks (Figure 37a-b). Most have four repeating sets of curvilinear to semi-circular ticked engraved lines. Other early historic Caddo sites with var. Darco vessels include the Hatchel (41BW3) and Sam Kaufman (41RR16, Skinner et al. 1969: Figure 21c) sites on the Red River.
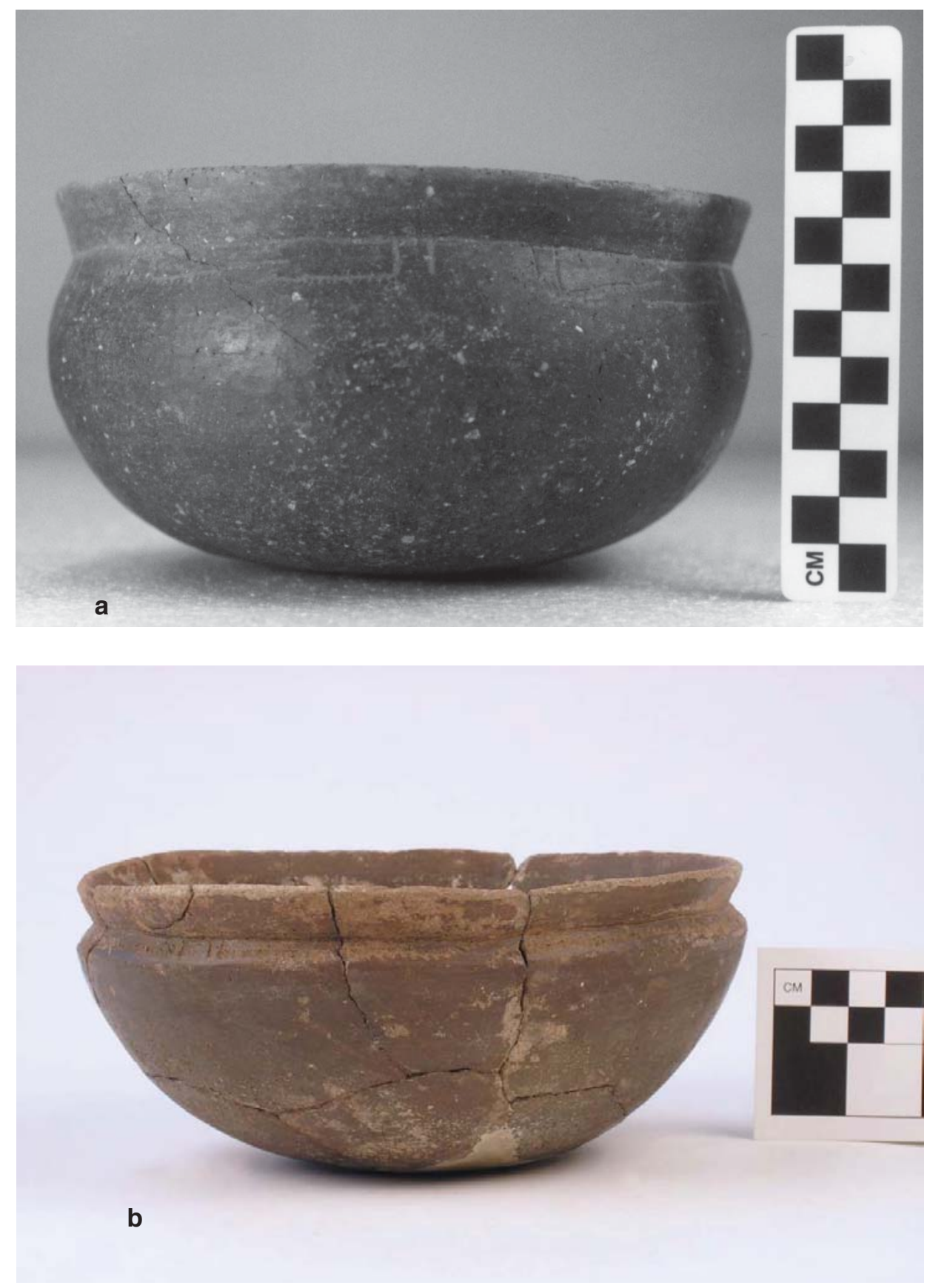

Figure 37. Darco Engraved, or Simms Engraved, var. Darco carinated bowls: a, Clements site (41CS25); b, Sam Kaufman (41RR16). 


\section{Ebarb Incised}

Gregory (1973) defined Ebarb Incised from ceramic sherds found at the Presidio de los Adaes (16NA16) in the Natchitoches, Louisiana, area, and he considers it a shell or bone-tempered type manufactured by the local Adaes. At Mission Dolores de los Ais (41SA25), in the mid-Sabine River basin, Corbin (2007:15) identified an engraved variety of Ebarb Incised, and this ware is primarily bone-tempered.

Ebarb Incised vessels, bowls and carinated bowls have two principal decorative motifs (Figure 38). The first includes a panel of opposed incised triangles filled with hatched lines pitched in opposite directions (Gregory and Avery 2007:45-47), and the second has a slanting scroll with upper and lower panels filled with either vertical or diagonal incised lines (Gregory 2007:47-48); one example from Los Adaes has a central and ticked scroll line.

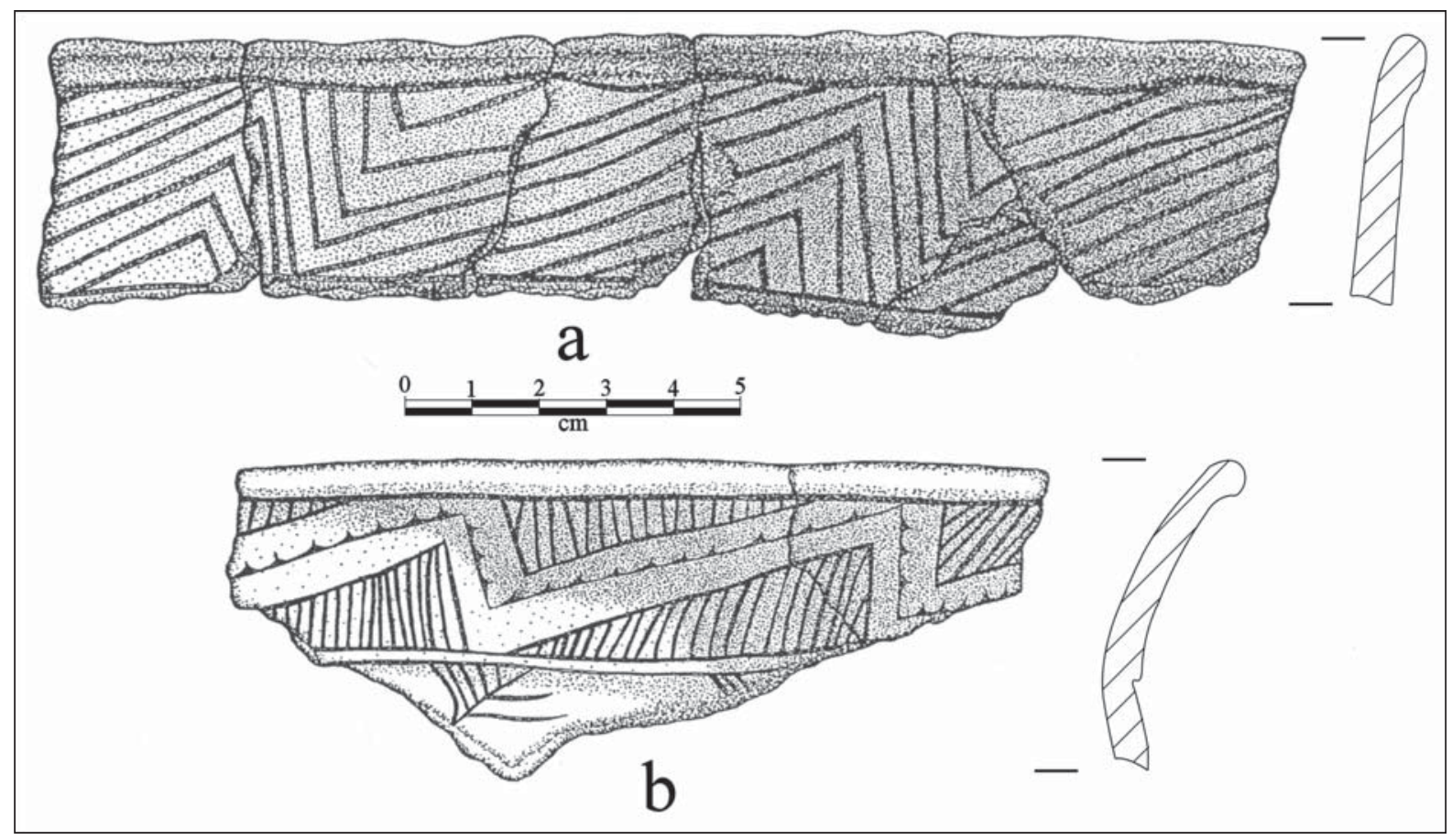

Figure 38. Ebarb Incised decorative motifs (after Gregory and Avery 2007). Images prepared by Lance Trask.

\section{Hatinu Engraved}

This is a distinctive late 17th-early 18th century Caddo fine ware type (Perttula et al. 2010). It is a spool-necked and red-slipped engraved bottle form. There are red-slipped scrolls and triangular areas in relief across the body and at the base of the vessel, and red-slipped areas around the scrolls and triangular areas have been scraped away (showing the original color of the vessel before it was slipped) to emphasize the distinctive red, raised, scrolls (Figure 39).

Other examples of Hatinu Engraved have been noted in collections at the Hatchel site (41BW3), the Friday site along the Red River in southwestern Arkansas (Moore 1912:Figures 106 and 107), the Battle site (John E. Miller, 2005 e-mail communication), in a private collection from another site in Arkansas (Townsend and Walker 2004:Figure 19), from sites in Clark County, Arkansas and the Carden Bottoms along the upper Arkansas River in southwestern Arkansas, and in a very late Titus phase site (Shelby, 41CP71) in the Big Cypress Creek basin in northeastern Texas. Bonds (2006:Figures 2, 83, 160, 432, 491, 523, 536, 541, 556, 585,628 , and 632) illustrates a number of unprovenienced Hatinu Engraved bottles that are in the hands of private collectors. 


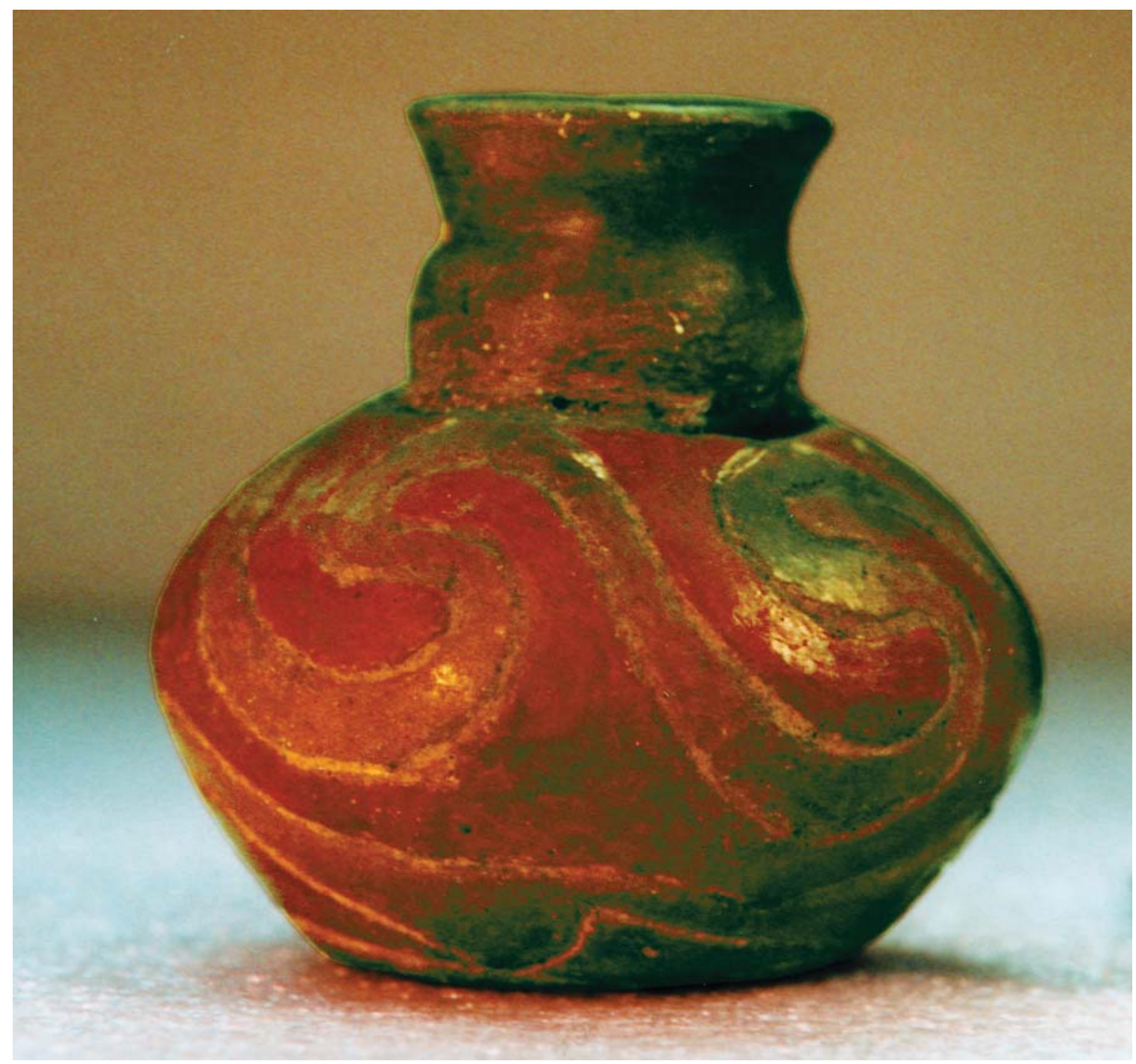

Figure 39. Hatinu Engraved bottle from the Clements site (41CS25).

\section{Henderson Plain}

This type is a grog and/or bone-tempered plain ware from Kinsloe phase sites (Jones 1968:163-166); shell-tempered Henderson Plain vessels are also described by Jones (1968:164). The type occurs as bottles (including ollas), flared rim jars, bowls, compound bowls, and carinated bowls. Jones (1968:166) also described Henderson Plain vessels from Kinsloe phase sites that were red-slipped or had a horizontal pinched row as a decorative element just below the lip.

\section{King Engraved}

King Engraved is an Allen phase fine ware found in ceramic assemblages in the Angelina River basin. Decorative elements include cross-hatched engraved zones, either in panels, in panel dividers, or in large bands oriented in several directions on the rim (Marceaux 2011:154) (Figure 40). 


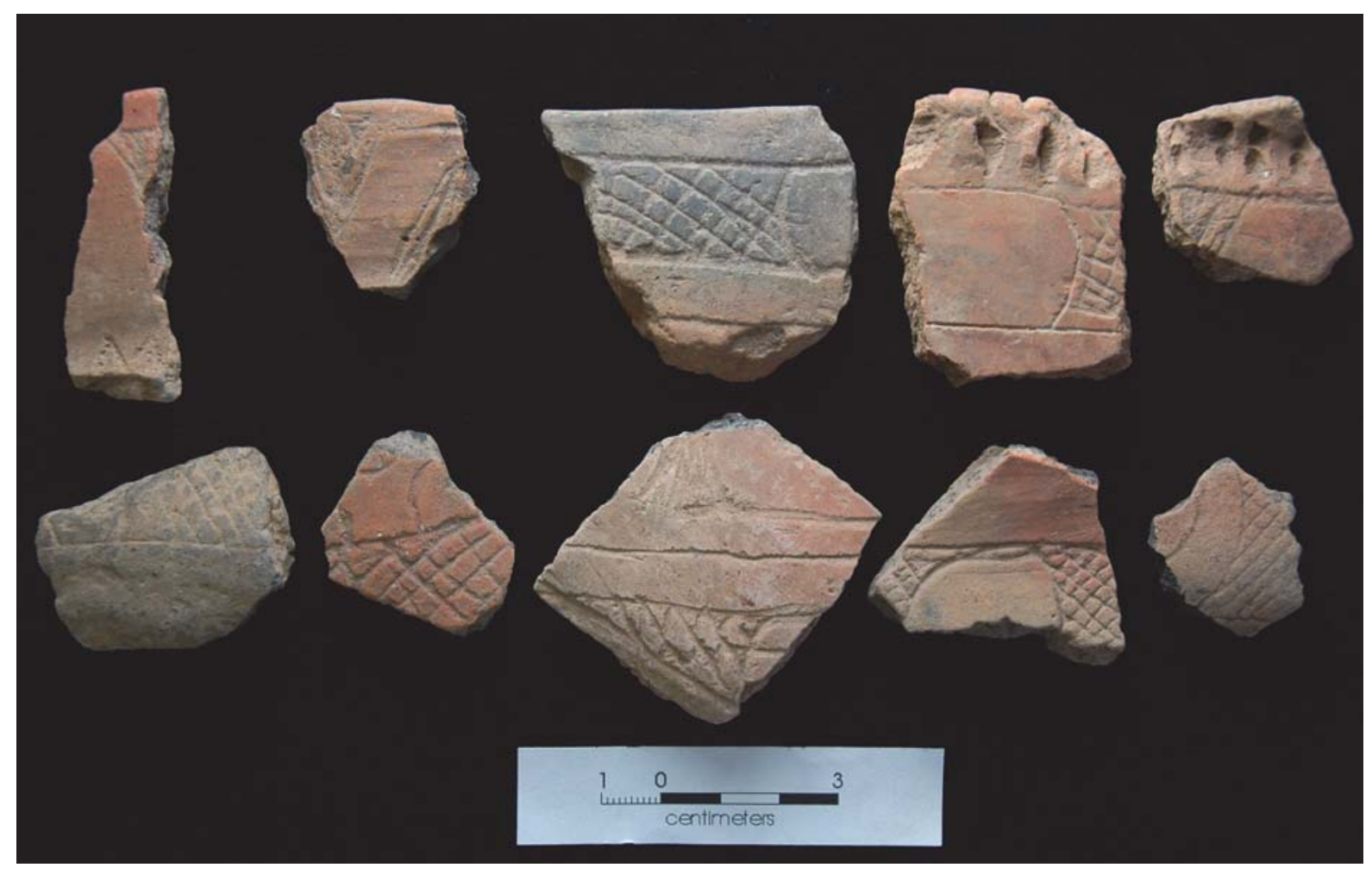

Figure 40. King Engraved rim sherds from Nacogdoches County sites.

\section{Lindsey Grooved}

Lindsey Grooved is an Allen phase utility ware type comprised of large bowls or jars with direct or slightly everted rims. The rims have shallow horizontal grooves (Marceaux 2011:140-141) (Figure 41). Lindsey Grooved vessels also occur in conjunction with appliqued, brushed, incised, or punctated elements, typically either at the rim-body juncture or on the vessel body.

\section{Mayhew Rectilinear}

This new type is described by Jackson et al. (2012:178 and Figures 3-58 and 4-8) from the Mayhew site (41NA21) and the Gallant Falls site (41NA344), an Allen phase component and an early 18th century Spanish mission, respectively, in the Angelina River basin. Sherds of this type have engraved or trailed rectilinear or curved lines; some sherds of the type have tick marks.

\section{Spradley Brushed-Incised}

This utility ware is found on Historic Caddo Allen phase sites in the Neches-Angelina river basins in East Texas. It consists of parallel brushing elements with overlapping straight incised lines that are opposed or perpendicular to the brushing (Marceaux 2011:140 and Figure 5.2) (Figure 42). 


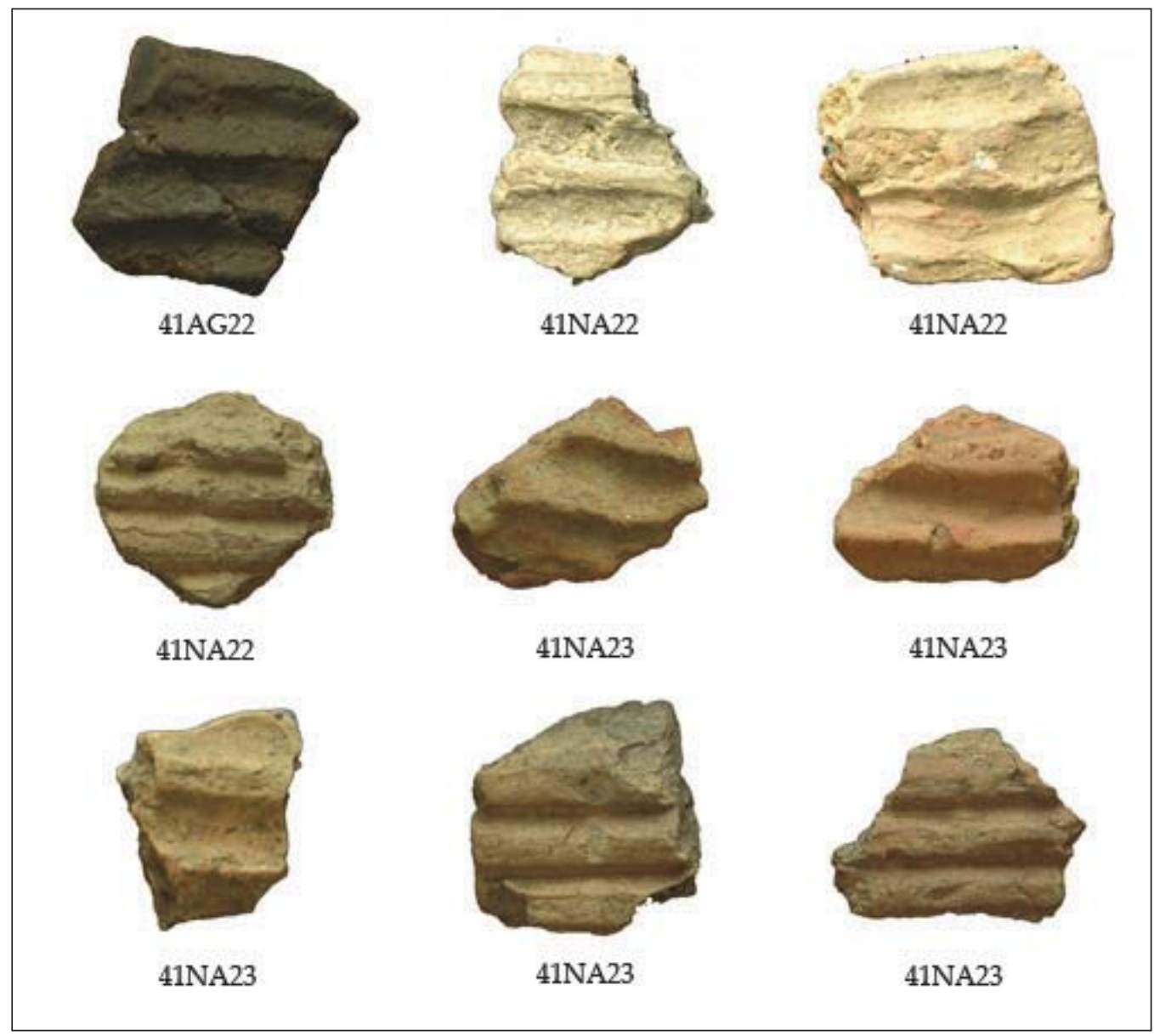

Figure 41. Lindsey Grooved sherds from historic Caddo sites in Angelina and Nacogdoches counties, Texas.

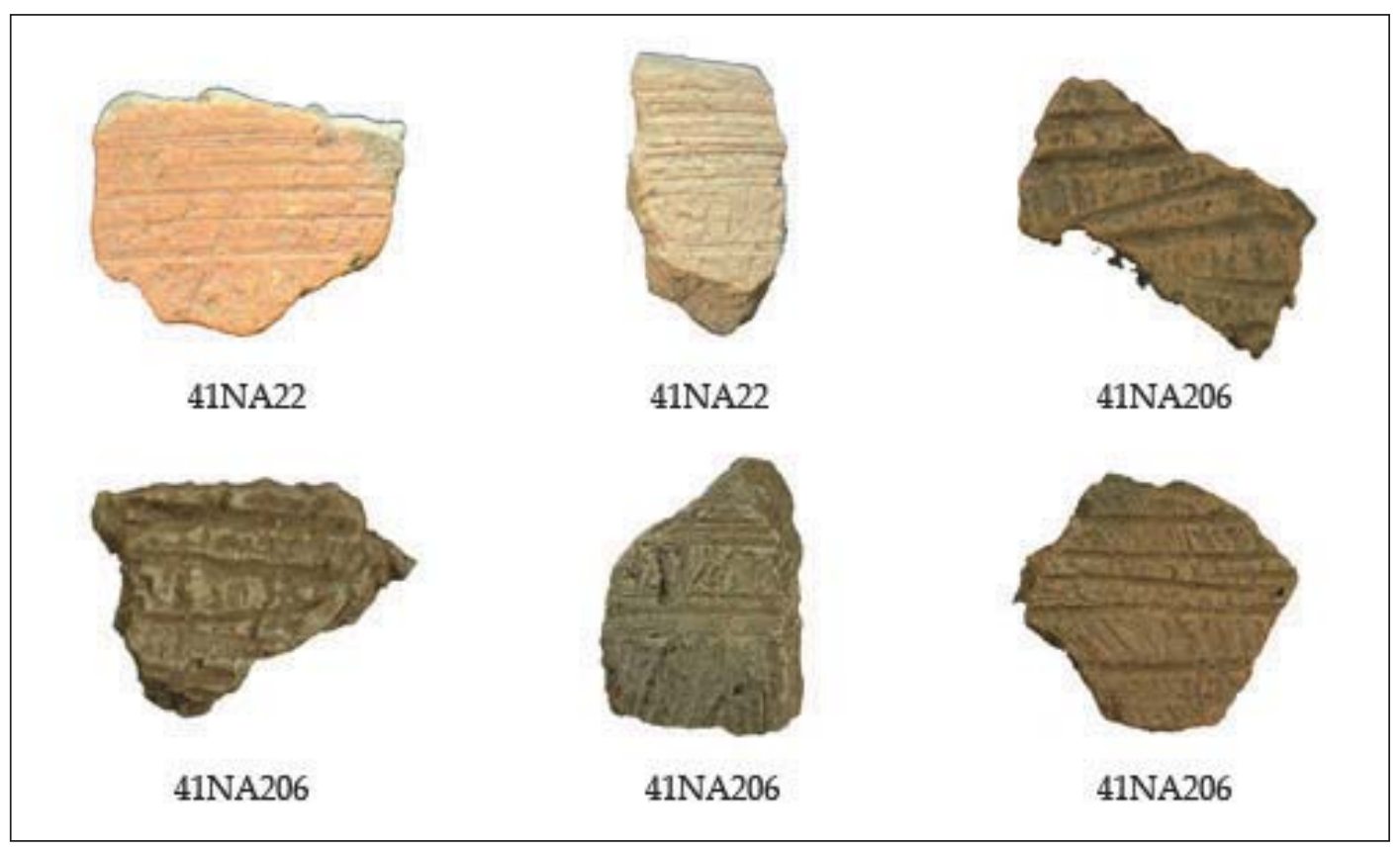

Figure 42. Spradley Brushed-Incised sherds from Nacogdoches County Caddo sites. 


\section{Womack Engraved}

Womack Engraved was defined by Duffield and Jelks (1961:36-39 and Figures 9 and 10) on the basis of vessels and sherds from sites in the Red and Sabine River basins in East Texas that date from the late 17 th century to the mid-18th century. Subsequent archaeological investigations have also identified Womack Engraved vessels and sherds from Caddo sites in the Little Cypress Creek basin.

Womack Engraved vessels tend to be carinated bowls with inverted rims. There are at least four or five known engraved rim motifs, including: opposed cross-hatched triangles; a negative meandering scroll with a ticked line running along the center of the scroll; parallel and arcing curvilinear lines; and a negative scroll with ticked lines and cross-hatched pendant triangles running down the center of the scroll (Figures 43 and 44a; see also Story et al. 1967:Figure 49). Another variety, var. Gum Creek, found in sites in the Little Cypress Creek basin, has a continuous series of engraved semi-circles on the rim panel (Figure 44b-c).

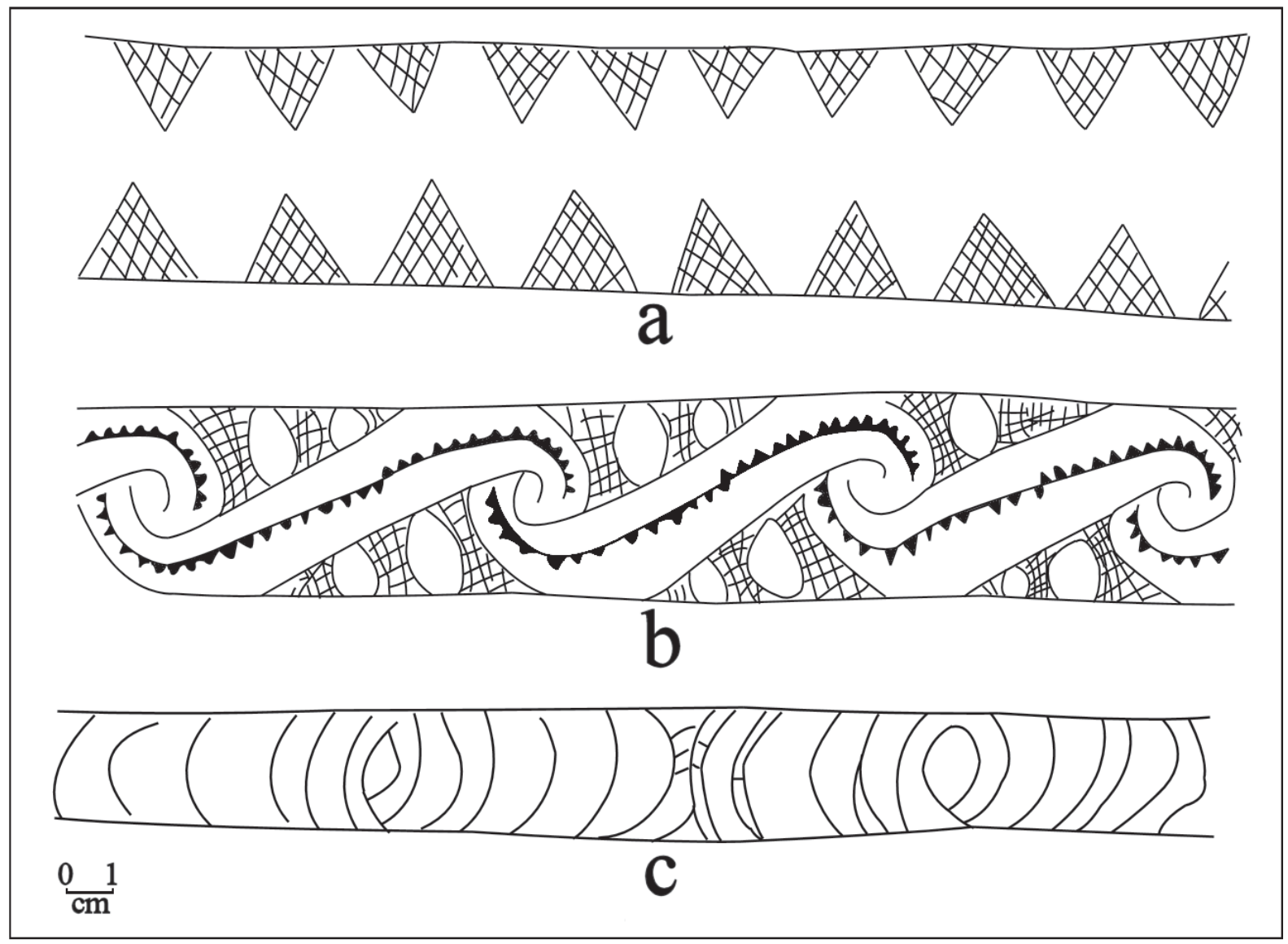

Figure 43. Womack Engraved rim motifs. 

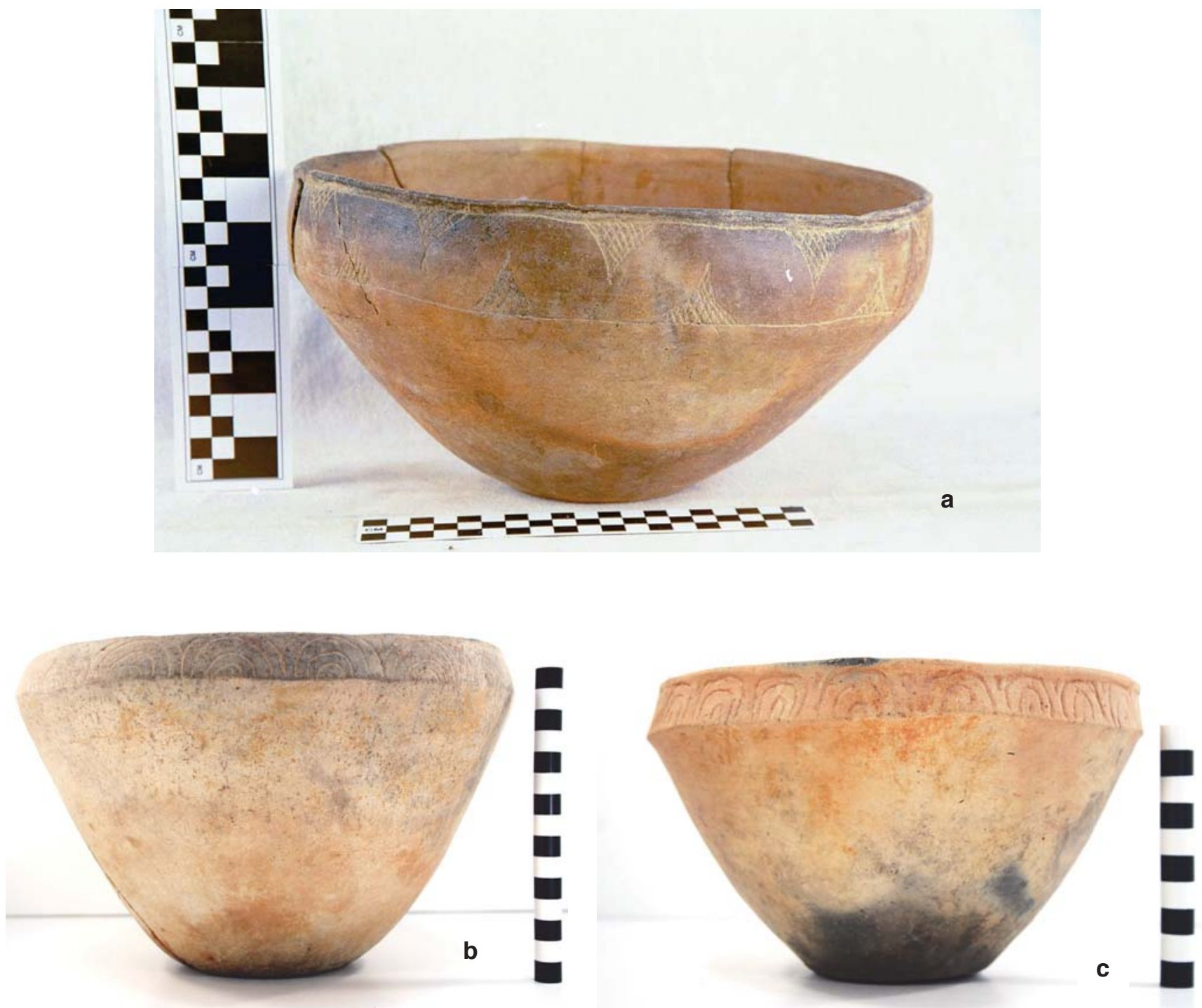

Figure 44. Womack Engraved vessels from East Texas sites.

\section{Womack Plain}

Womack Plain was defined by Story et al. (1967:146-148) from the plain ware assemblage recovered at the Gilbert site (41RA13) in the upper Sabine River basin. It is estimated to date to the mid-18th century. The type is represented by carinated bowls with inverted rims, as also seen in the Womack Engraved type. The vessels are tempered with mussel shell and have a fine sandy paste. 


\section{CERAMIC TYPES AND SETS IN THE LOWER SABINE AND NECHES-ANGELINA IN EAST TEXAS AND NORTHWEST LOUISIANA}

The distinctive Caddo ceramic vessels and sherds from the lower Sabine (i.e., Toledo Bend Reservoir, see McClurkan et al. 1966; Woodall 1969) and Neches-Angelina (i.e., Lake Sam Rayburn, see Jelks 1965) River basins were not included in the listing of ceramic types and sets in Table 1, due to current cultural phase taxonomic difficulties and poorly defined ceramic assemblages. Sites in these areas were included in the Angelina focus by Jelks (1965), which was a "broadly defined unit encompassing the entire Caddoan [sic] sequence in the Lake Sam Rayburn locality; needs reevaluation in light of larger sample of sites which are known in the area" (Story 1990:Table 43). Perttula (1992:253) used the term late Angelina focus to refer to sites in these localities that date after ca. A.D. 1400.

Sites at Toledo Bend Reservoir that have both ceramic vessels and decorated sherd assemblages include Salt Lick (16SA37a) and Bison, Area B (16SA30) (McClurkan et al. 1966; Woodall 1969). On the basis of the whole vessels from these sites, affiliations may be said to exist with the Titus phase, given the popularity of Ripley Engraved, Taylor Engraved, Karnack Brushed-Incised, and Wilder Engraved vessels in the burials (Table 2); Belcher Ridged vessels from Belcher phase sites are also funerary object inclusions in burials. However, it remains to be determined if any of these vessels were locally manufactured, or were vessels traded to a local Caddo community that lived in this part of the Sabine River basin (see Kelley 2006; Kelley et al. 2010).

Table 2. Ceramic vessels and sherds from selected sites at Toledo Bend Reservoir.

\begin{tabular}{|c|c|c|c|c|}
\hline \multirow[t]{2}{*}{ Ceramics } & \multicolumn{2}{|c|}{ Salt Lick } & \multicolumn{2}{|c|}{ Bison, Area B } \\
\hline & vessels & sherds & vessels & sherds \\
\hline Briarfield Plain olla & 1 & - & - & - \\
\hline Unidentified Plain ware & 2 & - & 6 & - \\
\hline Subtotal & 3 & - & 6 & - \\
\hline Avery Engraved & - & - & 1 & - \\
\hline Glassell Engraved & 1 & 6 & 1 & - \\
\hline Keno Trailed & - & 25 & - & - \\
\hline Natchitoches Engraved & - & 4 & - & - \\
\hline cf. Patton Engraved & 1 & - & - & - \\
\hline cf. Ripley Engraved & 4 & - & 20 & - \\
\hline Taylor Engraved & 6 & 5 & 12 & - \\
\hline Wilder Engraved & - & - & 7 & - \\
\hline Unidentified Engraved & 4 & 216 & 10 & 264 \\
\hline Subtotal & 19 & 256 & 57 & 264 \\
\hline Belcher Ridged & - & 48 & 7 & 194 \\
\hline Bullard Brushed & - & 6 & - & - \\
\hline Cass Appliqued & - & - & 1 & - \\
\hline Cowhide Stamped & - & 1 & - & - \\
\hline Harleton Appliqued & 3 & 4 & 1 & - \\
\hline Karnack Brushed-Incised & 5 & 13 & 6 & - \\
\hline Kiam Incised & - & 6 & - & - \\
\hline Pease Brushed-Incised & 1 & 5 & 1 & - \\
\hline Pineland Punctated-Incised & - & 39 & 2 & - \\
\hline Unidentified Appliqued & - & - & - & 13 \\
\hline
\end{tabular}


Table 2. Ceramic vessels and sherds from selected sites at Toledo Bend Reservoir, cont.

\begin{tabular}{lcccc}
\hline Ceramics & \multicolumn{2}{c}{ Salt Lick } & \multicolumn{2}{c}{ Bison, Area B } \\
& vessels & sherds & vessels & sherds \\
\hline Unidentified Brushed & - & 295 & 1 & 349 \\
Unidentified Incised & - & 462 & 4 & 393 \\
Unidentified Incised- & - & 17 & - & - \\
$\quad$ Punctated & - & 58 & 1 & 50 \\
Unidentified Punctated $\quad$ Subtotal & 9 & 954 & 24 & 999 \\
$\quad$ & & & 81 \\
\hline Totals & 28 & 1210 & & 1263 \\
\end{tabular}

The sherds from domestic contexts at these sites, as well as at the nearby Burnitt site (16SA204; Kelley 2006; Kelley et al.2010), are dominated by typologically unidentifiable fine ware and utility ware sherds as well as Belcher Ridged, incised, brushed, and Pineland Punctated-Incised sherds (see Table 2). The proportion of ridged utility wares at these sites is suggestive of a cultural connection with Belcher phase Caddo groups on the Red River (cf. Webb 1959). Until these assemblages of sherds and vessels can be restudied, it will be difficult to determine what a representative assemblage of ceramic fine ware and utility ware vessels and sherds from this part of the Sabine River basin looks like, and the differing affiliations of local Caddo groups (see Figures 4 and 5).

The same analytical deficiency exists with respect to the ceramic vessels and sherds in the Lake Sam Rayburn area on the Neches-Angelina in East Texas. Few of the vessels recovered from burials at Lake Sam Rayburn have been typologically identified (Table 3). The decorated sherds are dominated by Broaddus Brushed and Pineland Punctated-Incised sherds, along with considerable numbers of unidentifiable brushed, incised, and punctated utility wares and unidentified engraved fine wares.

Table 3. Ceramic vessels and sherds from selected sites at Lake Sam Rayburn.

\begin{tabular}{|c|c|c|c|c|c|c|}
\hline \multirow[t]{2}{*}{ Ceramics } & \multicolumn{2}{|c|}{ Walter Bell } & \multicolumn{2}{|c|}{ Wylie Price } & \multicolumn{2}{|c|}{ Print Bell } \\
\hline & vessels & sherds & vessels & sherds & vessels & sherds \\
\hline Unidentified Plain ware & 1 & - & 2 & - & 1 & - \\
\hline Belcher Ridged & - & 8 & - & - & - & - \\
\hline Broaddus Brushed & 1 & 2112 & - & 570 & - & 53 \\
\hline Davis Incised & - & 7 & - & - & - & - \\
\hline Dunkin Incised & - & 45 & - & - & - & - \\
\hline Pineland Punctated-Incised & 1 & 203 & - & 73 & - & 40 \\
\hline Unidentified Brushed & 2 & - & - & - & - & - \\
\hline Unidentified Incised & - & 1740 & 2 & 119 & - & 337 \\
\hline Unidentified Incised-Punctated & - & - & 1 & - & - & - \\
\hline Unidentified Punctated & 1 & 166 & - & 87 & - & 46 \\
\hline Glassell Engraved & 1 & - & - & - & - & - \\
\hline Unidentified Engraved & 1 & 200 & 1 & 152 & - & 61 \\
\hline Totals & 8 & 4281 & 6 & 1001 & 1 & 530 \\
\hline
\end{tabular}


The rarity of ridged sherds in the Lake Sam Rayburn sites when compared to their frequency in Toledo Bend Reservoir sites appears to indicate that the ancestral Caddo groups that once occupied these two areas had distinctly different utility ware traditions. Furthermore, stylistically-related Titus phase and Belcher phase engraved fine wares are absent in the Lake Sam Rayburn sites, much different from the Toledo Bend Reservoir ceramic assemblages (see Tables 2 and 3), a trend which may be indicative of differing populations of Caddo peoples. The Lake Sam Rayburn ceramic assemblages warrant a thorough reanalysis - paired with radiocarbon dates from organics (and organic residues on sherds and vessels) in the collections-before it will be possible to establish their temporal, stylistic, and compositional character and diversity, and explore their relationship to other ancestral Caddo ceramic traditions in East Texas and Northwest Louisiana.

\section{CONCLUSIONS}

Refining and further bracketing the age and intra-site chronological relationships of the ceramics from ancestral Caddo sites in East Texas remains to be fully accomplished, but work is underway through intensive radiocarbon dating efforts (including the dating of organic residues preserved on ceramic vessels and sherds). It is also important that the old and new ceramic types used in the region (including ceramic types yet to be recognized) be fully defined, and differences and similarities in ceramic decoration and manufacture be established in both print and digital venues. Such analyses can be employed to then answer questions regarding the social and cultural affiliation of ancestral Caddo groups, and the placement/occurrence of particular ceramic assemblages within specific communities of Caddo people.

This article represents our initial attempt at updating the current Caddo ceramic taxonomy to include updated age ranges for the ceramic types as well as provide descriptions of the more recently-defined ceramic types from East Texas and immediately contiguous areas. However, much work remains with regard to the refinement of type-specific chronologies as well as their distributions. It is our hope that the information presented here will aid in further refining our knowledge of ancestral Caddo ceramics. We believe it worth mentioning that all taxonomies are arbitrarily created constructs that remain malleable, and should persist in a continual state of change as knowledge grows and ceramic taxonomies prove useful or not given the research problems and interests of Caddo archaeologists.

While it has taken far too long for us - East Texas Caddo archaeologists - to begin updating the now $60+$ year old ceramic taxonomy for the region, we are making large strides toward the development of a publicly-available digital resource that will provide new images, chronometric dates, and spatial distributions for identified ceramic types. This article represents a foray into this realm, and we have high hopes that through the employment of those data from both vessel and sherd analyses, we can continue to improve upon the taxonomic classifications of ancestral Caddo ceramics in East Texas.

\section{ACKNOWLEDGMENTS}

Thanks to Shawn Marceaux, Tom Middlebrook, Jeff Girard, and John Samuelsen for providing images of certain types discussed in this article. Lance Trask and Sandra Hannum prepared several figures use herein. 


\section{REFERENCES CITED}

Bonds, J.

2006 Art of the Ancient Caddo. Grove Hill Publishing, Leonard, Texas.

Brown, J. A.

1996 The Spiro Ceremonial Center. The Archaeology of Arkansas Valley Caddoan Culture in Eastern Oklahoma. 2 Vols. Memoir No. 29. Museum of Anthropology, University of Michigan, Ann Arbor.

Bruseth, J. E. and T. K. Perttula

1981 Prehistoric Settlement Patterns at Lake Fork Reservoir. Texas Antiquities Permit Series, Report No. 2. Texas Antiquities Committee and Southern Methodist University, Austin and Dallas.

Corbin, J. E.

2007 Cultural Diversity in the Southern Caddo Region. Journal of Northeast Texas Archaeology 26:11-23.

Duffield, L. F. and E. B. Jelks

1961 The Pearson Site: A Historic Indian Site at Iron Bridge Reservoir, Rains County, Texas. Archaeology Series No. 4. Department of Anthropology, The University of Texas at Austin.

Durham, J. H. and M. K. Davis

1975 Report on Burials found at Crenshaw Mound "C," Miller County, Arkansas. Bulletin of the Oklahoma Anthropological Society 23:1-90.

Early, A. M.

2012 Form and Structure in Prehistoric Caddo Pottery Design. In The Archaeology of the Caddo, edited by T. K. Perttula and C. P. Walker, pp. 26-46. University of Nebraska Press, Lincoln.

Gadus, E. F.

2013 Twisted Serpents and Fierce Birds: Structural Variation in Caddo Engraved Ceramic Bottle Motifs. Bulletin of the Texas Archeological Society 84:213-245.

Gregory, H. F.

1973 Eighteenth Century Caddoan Archaeology: A Study in Models and Interpretation. Ph.D. dissertation, Department of Anthropology, Southern Methodist University, Dallas.

Gregory, H. F. and G. Avery

2007 American Indian Pottery from Historic Period Sites in North Louisiana. Journal of Northeast Texas Archaeology 26:33-76.

Harris, R. K., I. M. Harris, J. C. Blaine, and J. Blaine

1965 A Preliminary Archeological and Documentary Study of the Womack Site, Lamar County, Texas. Bulletin of the Texas Archeological Society 36:287-365.

Hart, J. P.

1982 An Analysis of the Aboriginal Ceramics from the Washington Square Mound Site, Nacogdoches County, Texas. Master's thesis, Department of Anthropology, Northeast Louisiana University, Monroe.

Hart, J. P., and J. E. Corbin

1984 An Analysis of the Aboriginal Ceramics from the Washington Square Mound Site, Nacogdoches County, Texas. Papers in Anthropology No. 6. Stephen E Austin State University, Nacogdoches.

Jackson, M. K., T. Middlebrook, G. Avery, H. Shafer, and B. Meissner

2012 Trade and Cultural Interaction along El Camino Real de los Tejas During the Spanish Colonial and Republic Periods in Nacogdoches County, Texas. 2 Vols. Nine Flags Museum, Nacogdoches. 
Jelks, E. B.

1961 Excavations at Texarkana Reservoir, Sulphur River, Texas. River Basin Survey Papers No. 21. Bureau of American Ethnology, Smithsonian Institution, Washington, D.C.

1965 The Archeology of McGee Bend Reservoir, Texas. Ph.D. dissertation, Department of Anthropology, The University of Texas at Austin.

Jones, B. C.

1968 The Kinsloe Focus: A Study of Seven Historic Caddoan Sites in Northeast Texas. Master's thesis, Department of Anthropology, University of Oklahoma, Norman.

Kelley, D. B.

2006 The Burnitt Site: A Late Caddoan Occupation in the Uplands of the Sabine River Basin of Louisiana. Coastal Environments, Inc., Baton Rouge.

Kelley, D. B., D. G. Hunter, K. M. Roberts, S. L. Scott, and B. S. Haley

2010 The Burnitt Site (16SA204): A Late Caddoan Occupation in the Uplands of the Sabine River Basin. Louisiana Archaeology 31:4-33.

Krieger, A. D.

1946 Culture Complexes and Chronology in Northern Texas, with Extensions of Puebloan Datings to the Mississippi Valley. Publication No. 4640. The University of Texas, Austin.

Marceaux, P. S.

2011 The Archaeology and Ethnohistory of the Hasinai Caddo: Material Culture and the Course of European Contact. Ph.D. dissertation, Department of Anthropology, The University of Texas at Austin.

McClurkan, B. B., W. T. Field, and J. N. Woodall

1966 Excavations in Toledo Bend Reservoir, 1964-65. Papers of the Texas Archeological Salvage Project No. 8. Texas Archeological Salvage Project, The University of Texas at Austin.

Middlebrook, T. A.

1994 An Update of Archaeological Investigations at the Tyson Site. Journal of Northeast Texas Archaeology $3: 1-36$

Moore, C. B.

1912 Some Aboriginal Sites on Red River. Journal of the Academy of Natural Sciences of Philadelphia 14(4):526-636.

Parsons, $\mathrm{M}$.

2011 Mitigation Phase Archeological Investigations at Lake Gilmer, Upshur County, Texas. MS on file, Archeology Division, Texas Historical Commission, Austin.

Perino, G.

1981 Archeological Investigations at the Roden Site (MC-215), McCurtain County, Oklahoma. Potsherd Press No. 1. Museum of the Red River, Idabel.

1983 Archaeological Research at the Bob Williams Site (41RR16), Red River County, Texas. Museum of the Red River, Idabel.

1994 Archaeological Research at the Rowland Clark Site (41RR77), Red River County, Texas. Journal of Northeast Texas Archaeology 4:3-42.

Perttula, T. K.

1992 "The Caddo Nation": Archaeological and Ethnohistoric Perspectives. University of Texas Press, Austin.

2008 The Decorated Caddo Vessel Sherds and Plain Vessel Rims from the Leaning Rock Site (41SM325), Smith County, Texas. Caddo Archeology Journal 17:27-42. 
2009 The Archaeology of the 16th and 17th Century Caddo in the Post Oak Savannah of Northeast Texas: The Tuinier Farm (41HP237), R. A. Watkins (41HP238), and Anglin (41HP240) Sites in the Stouts Creek Basin, Hopkins County, Texas. Journal of Northeast Texas Archaeology 30:1-132.

2011 (assembler) Archaeological and Archaeogeophysical Investigations at an Early Caddo Mound Center in the Sabine River Basin of East Texas, Special Publication No. 15. Friends of Northeast Texas Archaeology, Austin and Pittsburg.

2013 Caddo Ceramics in East Texas. Bulletin of the Texas Archeological Society 84:181-212.

Perttula, T. K., D. B. Kelley, and R. A. Ricklis (assemblers and editors)

2011 Archeological Investigations at the Lang Pasture Site (41AN38) in the Upper Neches River Basin of East Texas. Report No. 129. Texas Department of Transportation, Archeological Studies Program, Environmental Affairs Division, Austin.

Perttula, T. K., B. Nelson, and R. Z. Selden, Jr.

2014 The Gardener Site (41CP55): a Late Caddo Settlement on Big Cypress Creek in East Texas. Journal of Northeast Texas Archaeology 44:1-11.

Perttula, T. K., B. Nelson, R. L. Cast, and B. Gonzalez

2010 The Clements Site (41CS25): A Late 17th to Early 18th-Century Nasoni Caddo Settlement and Cemetery. Anthropological Papers No. 92. American Museum of Natural History, New York.

Perttula, T. K., B. Nelson, and M. Walters

2012 Caddo Archaeology at the Henry Spencer Site (41UR315) in the Little Cypress Creek Basin of East Texas. Special Publication No. 20. Friends of Northeast Texas Archaeology, Pittsburg and Austin.

Perttula, T. K., M. Tate, H. Neff, J. W. Cogswell, M. D. Glascock, E. Skokan, S. Mulholland, R. Rogers, and B. Nelson

1998 Analysis of the Titus Phase Mortuary Assemblage at the Mockingbird Site Kahbakayammaahin" (41TT550). Document No. 970849. Espey, Huston \& Associates, Inc., Austin.

Perttula, T. K., M. Walters, S. Marceaux, and B. Nelson

2009 Caddo Pottery Vessels and Pipes from Sites in the Middle and Upper Sabine and Upper Neches River Basins, Smith and Wood Counties, Texas. Special Publication No. 7. Friends of Northeast Texas Archaeology, Pittsburg and Austin.

Perttula, T. K., M. Walters, and B. Nelson

2010 Caddo Pottery Vessels and Pipes from the Johns Site (41CP12) in the Big Cypress Creek Basin in the Turner and Johns Collections, Camp County, Texas. Special Publication No. 11. Friends of Northeast Texas Archaeology, Austin and Pittsburg.

Phillips, P.

1970 Archaeological Survey in the Lower Yazoo Basin, Mississippi, 1949-1955. Papers of the Peabody Museum of Archaeology and Ethnology 60, 2 Vols. Peabody Museum of Archaeology and Ethnology, Harvard University, Cambridge.

Skinner, S. A., R. K. Harris, and K. M. Anderson (editors)

1969 Archaeological Investigations at the Sam Kaufman Site, Red River County, Texas. Contributions in Anthropology No. 5. Department of Anthropology, Southern Methodist University, Dallas.

Stokes, J. and J. Woodring

1981 Native-Made Artifacts of Clay. In Archeological Investigations at the George C. Davis Site, Cherokee County, Texas: Summers of 1979 and 1980, edited by D. A. Story, pp. 135-238. Occasional Paper No. 1. Texas Archeological Research Laboratory, The University of Texas at Austin. 
Story, D. A.

1990 Cultural History of the Native Americans. In The Archeology and Bioarcheology of the Gulf Coastal Plain, by D. A. Story, J. A Guy, B. A. Burnett, M. D. Freeman, J. C. Rose, D. G. Steele, B. W. Olive, and K. J. Reinhard, pp. 163-366. Research Series No. 38. 2 Vols. Arkansas Archeological Survey, Fayetteville.

Story, D. A. and E. B. Jelks

2009 Foreword. In Handbook of Texas Archeology: Type Descriptions, edited by D. A. Suhm and E. B. Jelks, pp. 1-5. Reprint Edition, Gustav's Library, Davenport, Iowa.

Story, D. A., B. Barber, E. Cobb, H. Cobb, R. Coleman, K. Gilmore, R. K. Harris, and N. Hoffrichter

1967 Pottery Vessels. In "The Gilbert Site: A Norteno Focus Site in Northeast Texas," edited by E. B. Jelks. Bulletin of the Texas Archeological Society 37:112-187.

Suhm, D. A. and E. B. Jelks (editors)

1962 Handbook of Texas Archeology: Type Descriptions. Special Publication No. 1, Texas Archeological Society, and Bulletin No. 4, Texas Memorial Museum, Austin.

Suhm, D. A., A. D. Krieger, and E. B. Jelks

1954 An Introductory Handbook of Texas Archeology. Bulletin of the Texas Archeological Society 25:1-562.

Townsend, R. P. and C. P. Walker

2004 The Ancient Art of Caddo Ceramics. In Hero, Hawk, and Open Hand: American Indian Art of the Ancient Midwest and South, edited by R. P. Townsend, pp. 231-245. Art Institute of Chicago and Yale University Press, Chicago and New Haven.

Turner, R. L.

1978 The Tuck Carpenter Site and Its Relations to Other Sites within the Titus Focus. Bulletin of the Texas Archeological Society 49:1-110.

Walters, $\mathrm{M}$.

2006 The Lake Clear (41SM243) Site and Crotalus horridus atricaudatus. Caddoan Archeology Journal 15:5-41.

Webb, C. H.

1959 The Belcher Mound, a Stratified Caddoan Site in Caddo Parish, Louisiana. Memoirs No. 16. Society for American Archaeology, Salt Lake City.

Webb, C. H. and R. R. McKinney

1975 Mounds Plantation (16CD12), Caddo Parish, Louisiana. Louisiana Archaeology 2:39-127.

Wood, W. R.

1962 The Crenshaw Site: A Coles Creek and Caddoan Mound Group in Miller County, Arkansas. University of Arkansas Museum, Fayetteville.

Woodall, J. N.

1969 Archeological Excavations in the Toledo Bend Reservoir, 1966. Contributions in Anthropology No. 3. Department of Anthropology, Southern Methodist University, Dallas. 